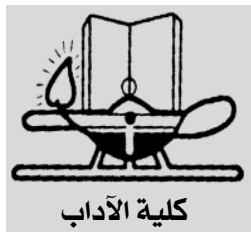

حوليات آداب عين شمس (عدد خاص 1 ( م ب) http://www.aafu.journals.ekb.eg

(دورية علمية محكمة)

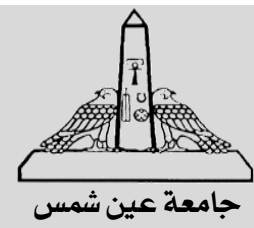

\title{
اسم التفضيل في سنن ابن ماجة دراسة صرفية دلالية
}

سالمة امحمد سالم احفيظة

عضو هيئة تدريس- جامعة الزاوية - ليبيا

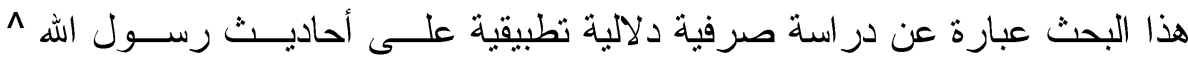

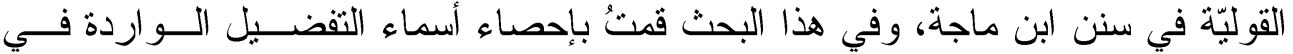

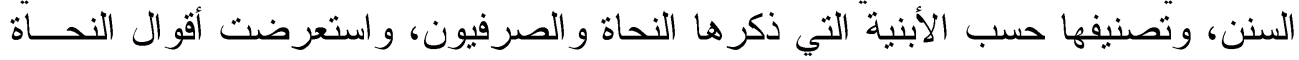

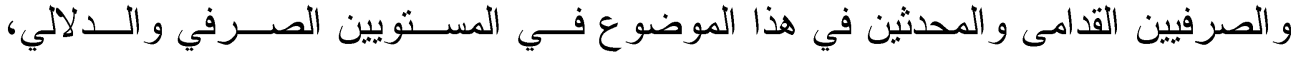

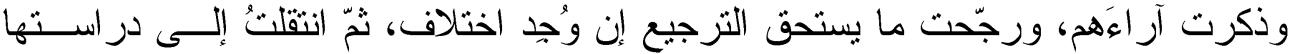

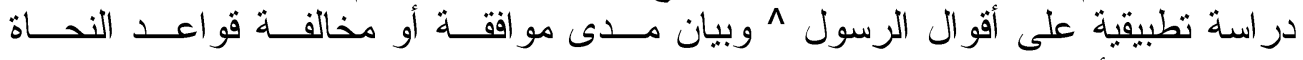

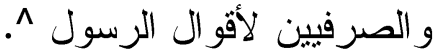
وقد اشتمل هذا البحث على مقدمة، وتمهيد، ومتن الدراسة، وخاتمة ذكرت فيها أهم

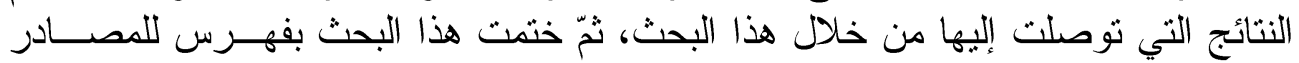
و المر اجع التي ساعدنتي في إعداده. 


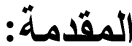

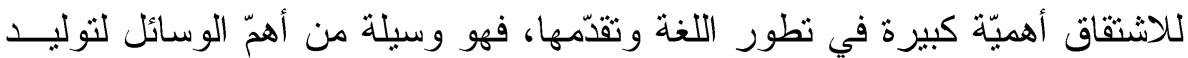

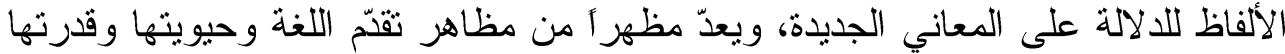

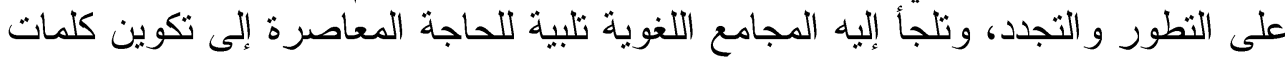
عربيّة لم ترد في المعجمات العربيّة، وتصلح للتعبير عن المفاهيم المستحدثة.

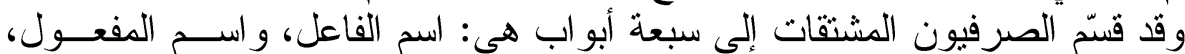

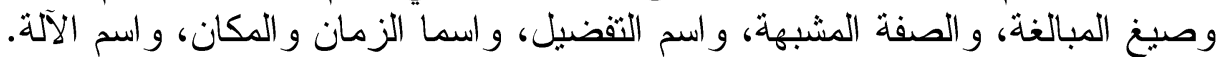

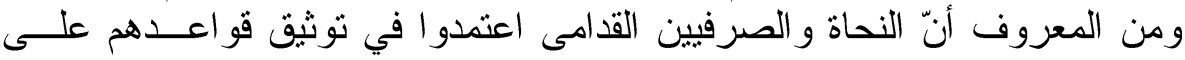

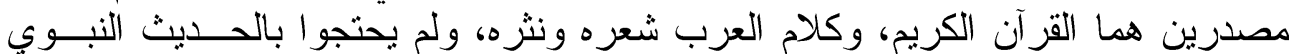

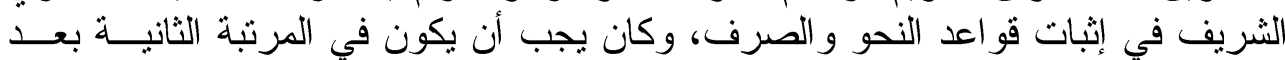

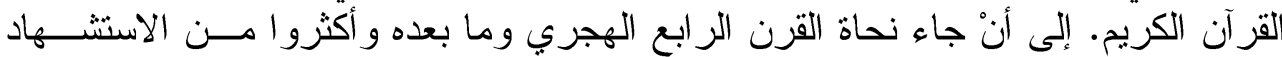

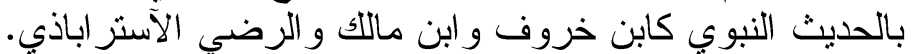

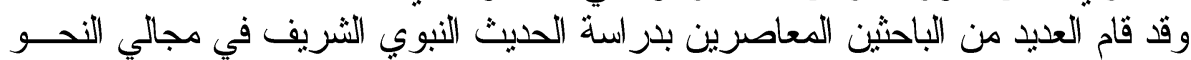

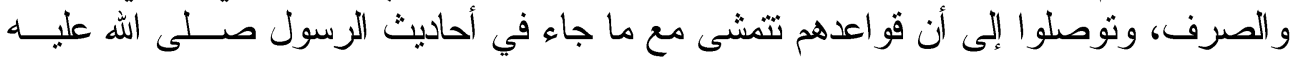

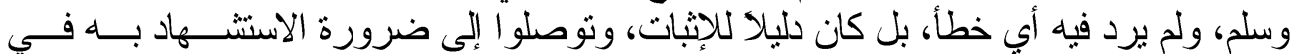

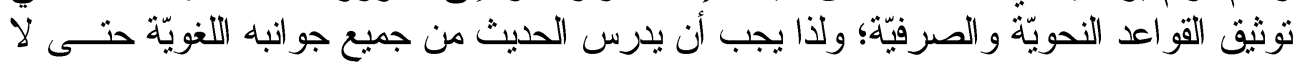

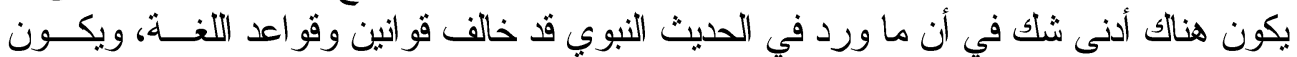

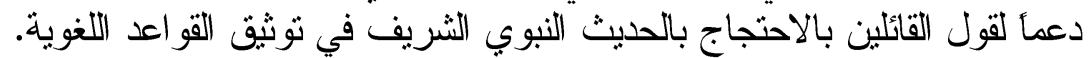

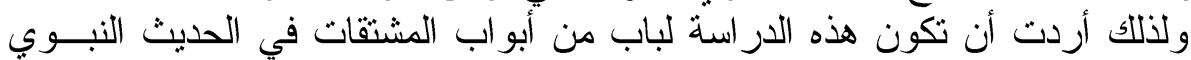

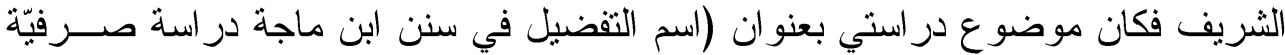

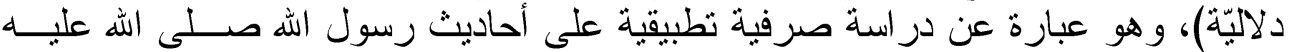

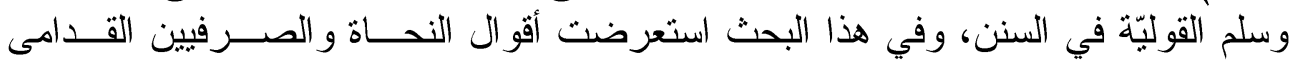

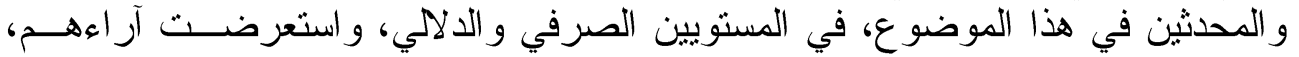

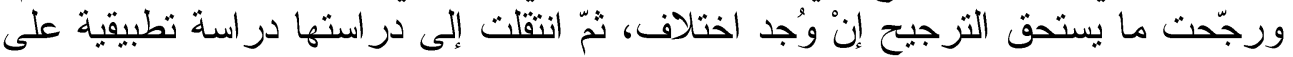

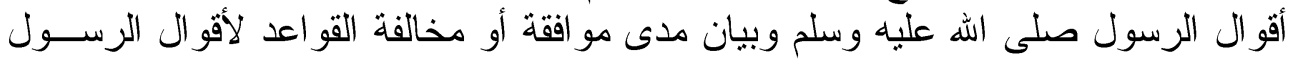

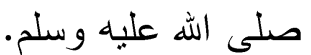

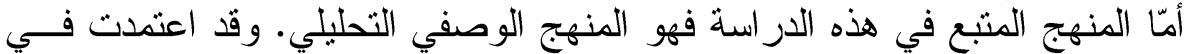

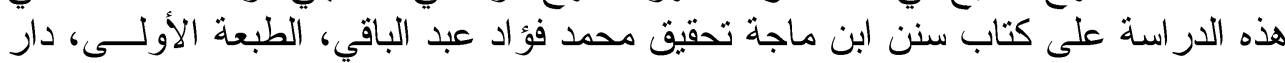

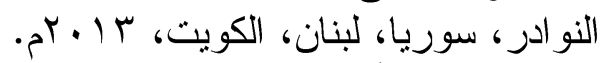

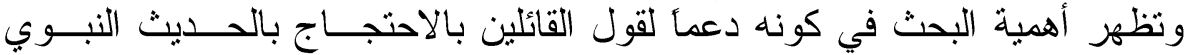

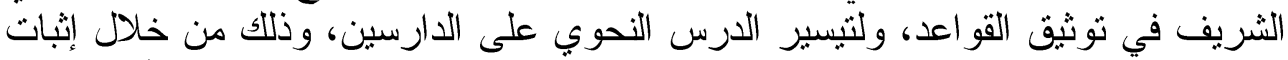

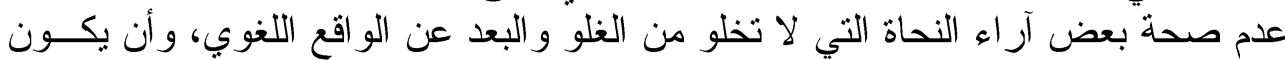

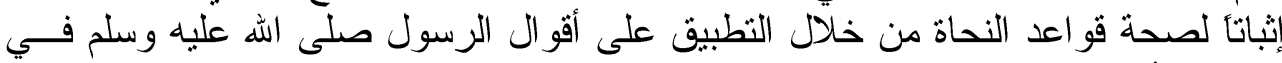

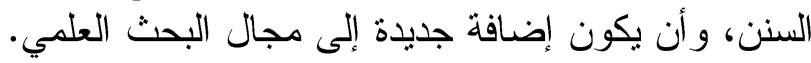

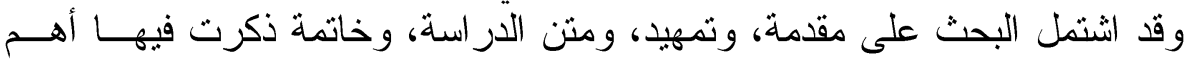
نتائج البحث، وفهرس لمصادر ومر اجع هذا البحث. 


\section{|التمــ|}

\section{ترجمة الإمام ابن ماجة:}

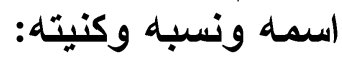

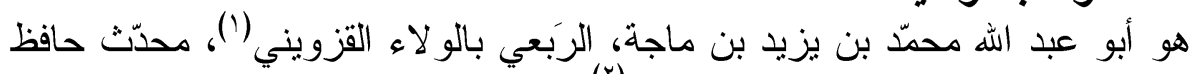

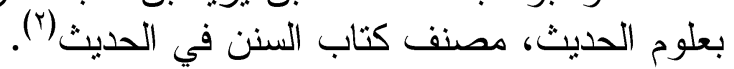

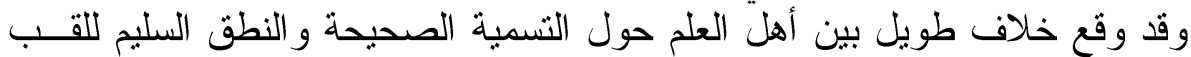

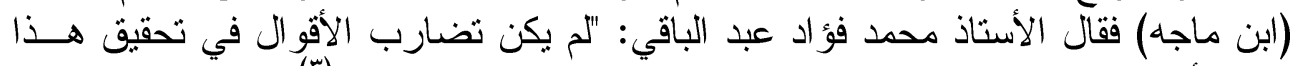

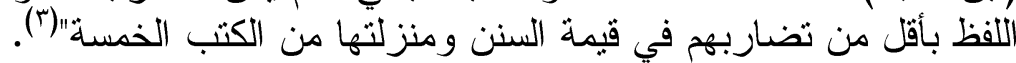

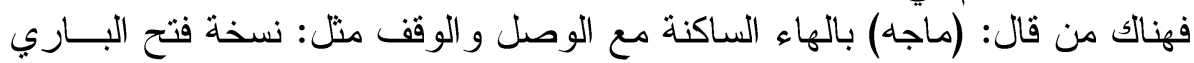

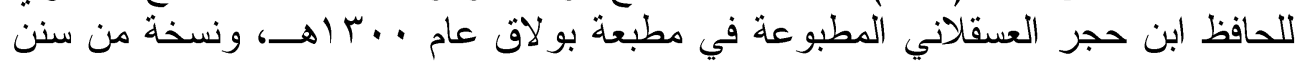

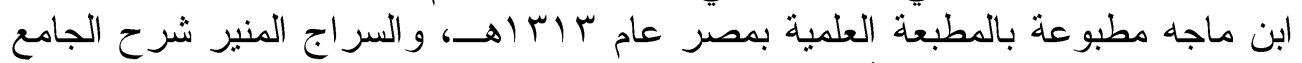
الصغير المطبو ع بالمطبعة الأزهرية.

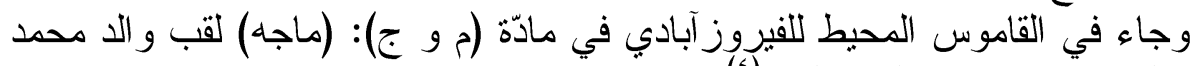
بن بزيد القزويني صاحب في السنن لجدّه"(؛).

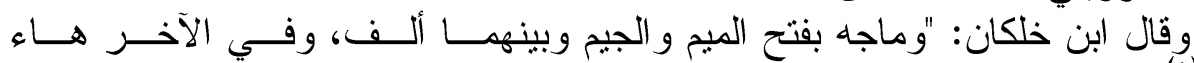

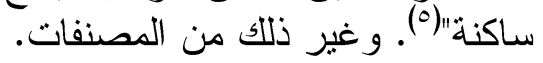

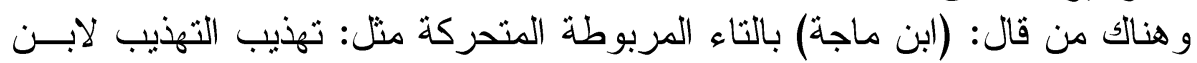

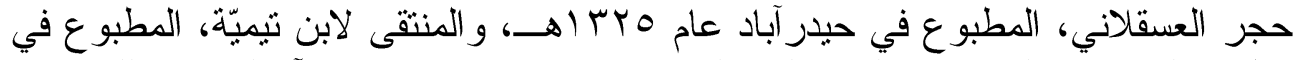

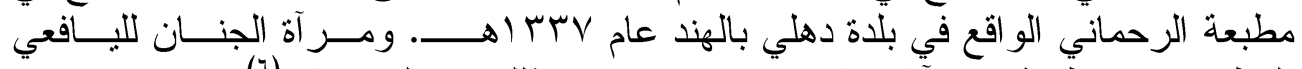

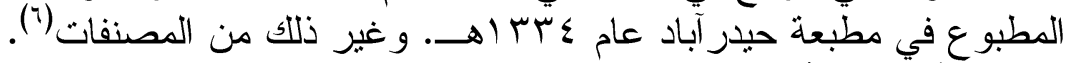

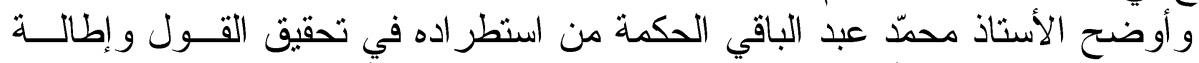

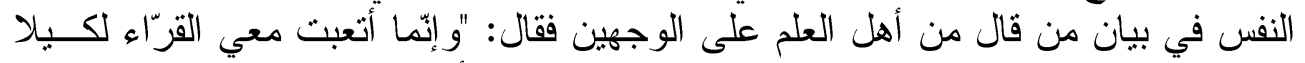

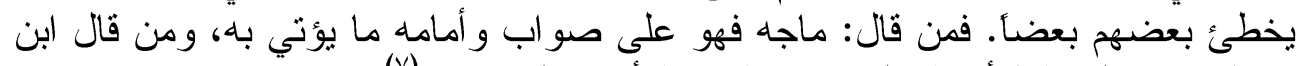

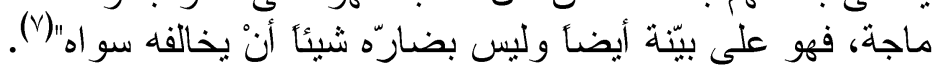

مولاده:

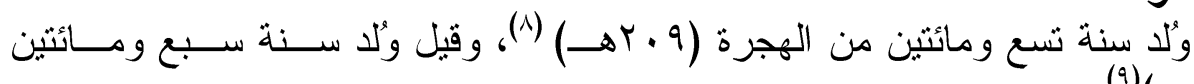
(9) (ד. $(\rightarrow)$ رحلاته:

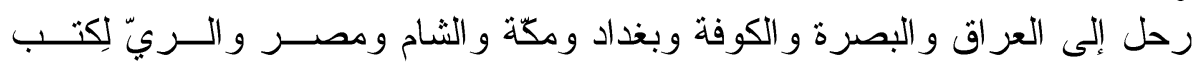

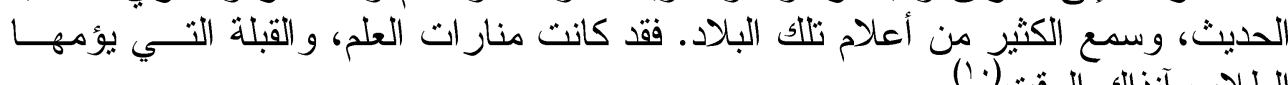

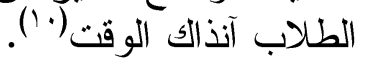
شيوخه:

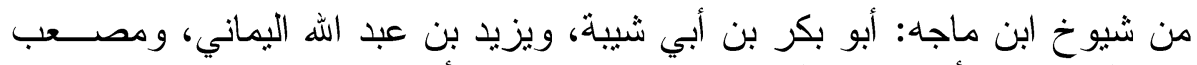

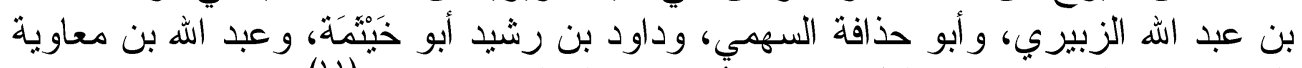

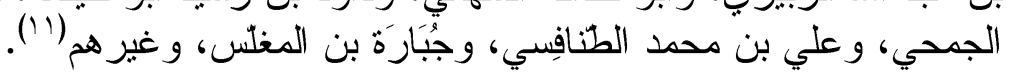




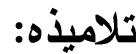

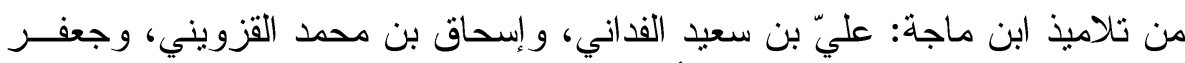

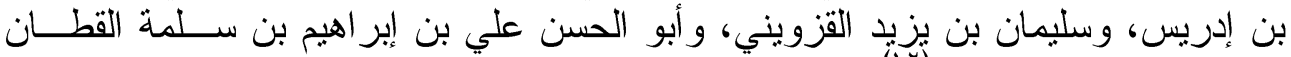

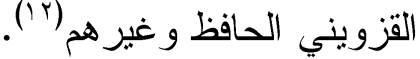
مؤلفاته و آثثاره الكلمية همية:

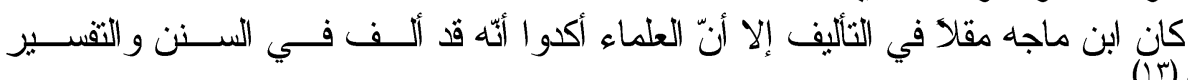

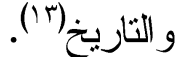

ففي الحديث ألف كتابه (سنن ابن ماجه) و الذي يبدو أنّ جلّ من ثرجم لله ذكر كتابه

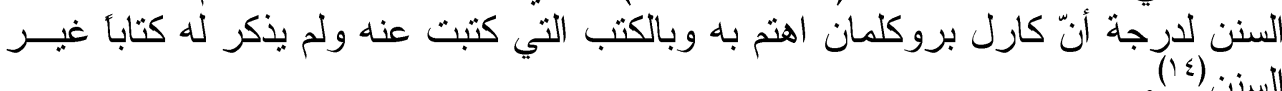
وفي التفسير ألف كتابأ في تقسير القرآن العظيم، قال ابن كثير : "ولابن ماجة تفسير

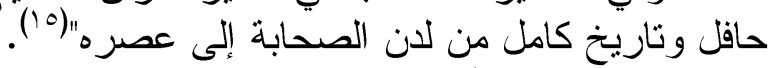

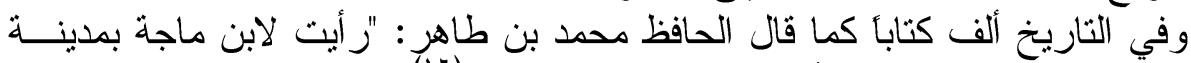

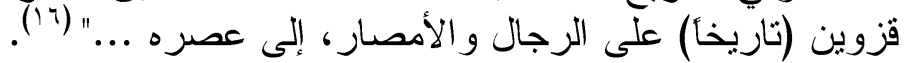

$$
\begin{aligned}
& \text { ثناء العلماء عليه ومكانته: }
\end{aligned}
$$

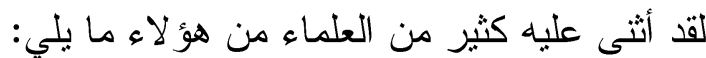

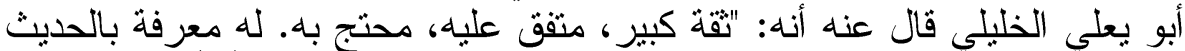

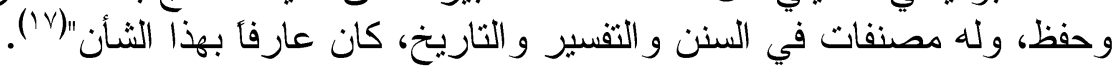

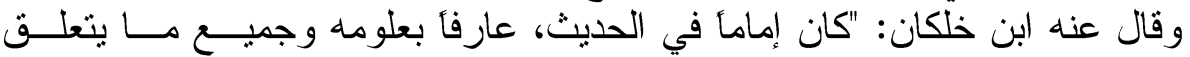

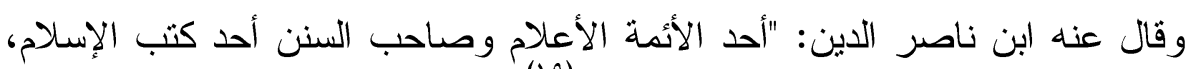
حافظ، ثقة، كبير ، صنف السن ناصن و السن والتاريخ و التقسير" (19).

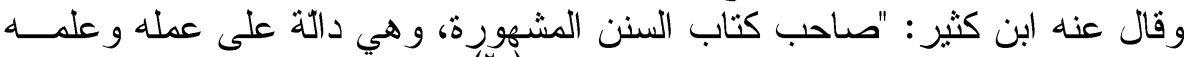

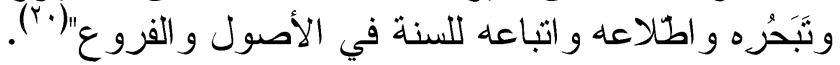

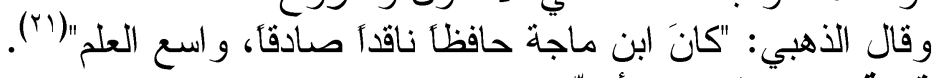
قيمة كتاب السنن وأهميّيته:

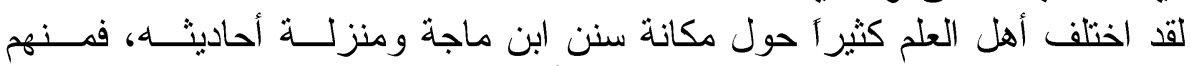

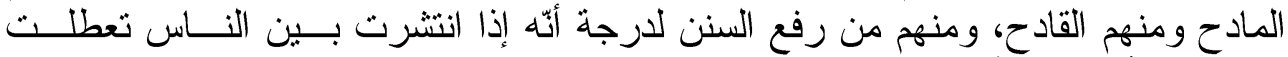

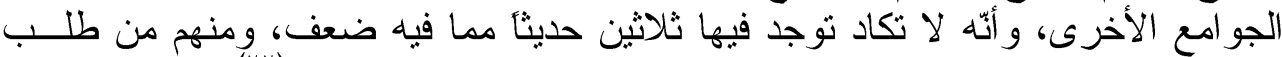

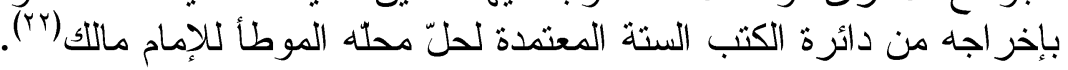

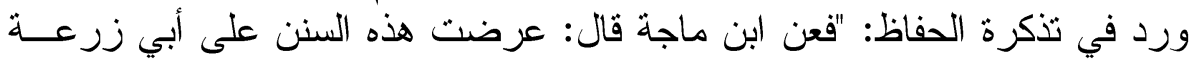

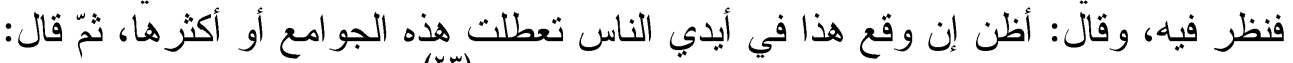

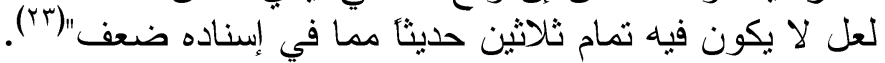

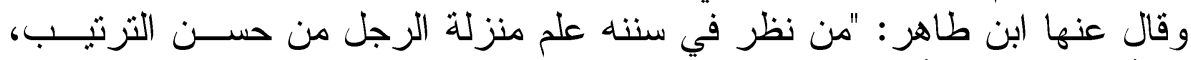

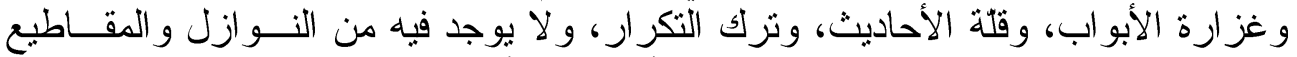

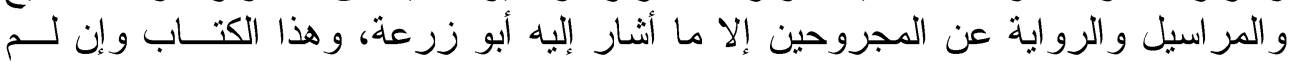

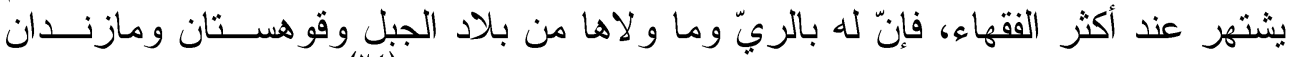

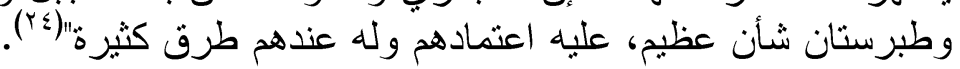




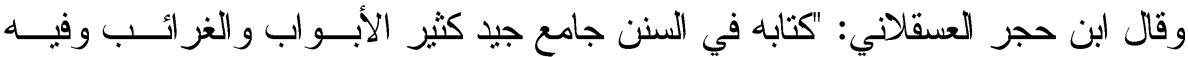

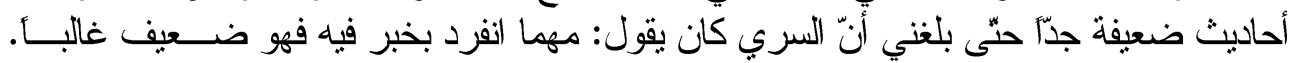

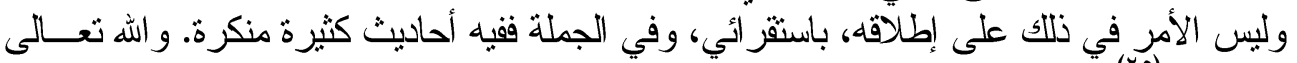

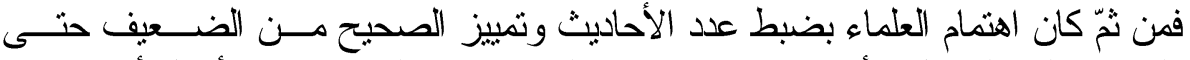

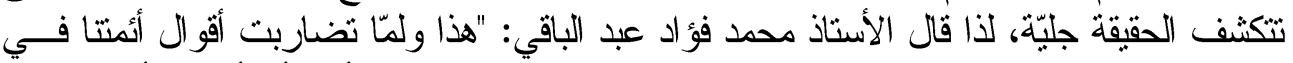

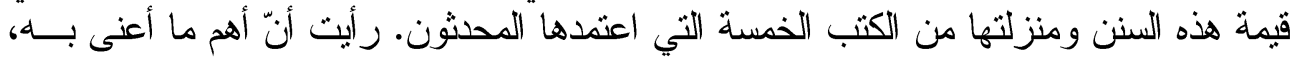

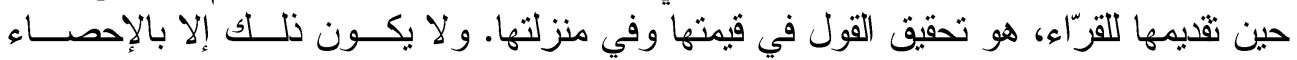

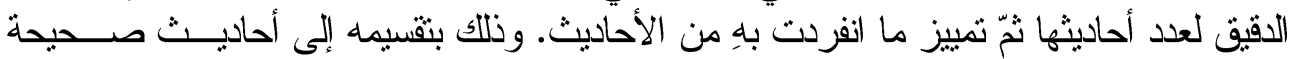

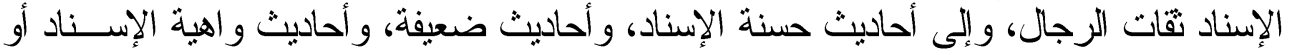

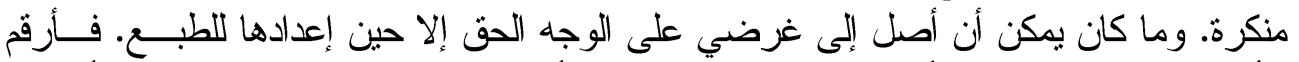

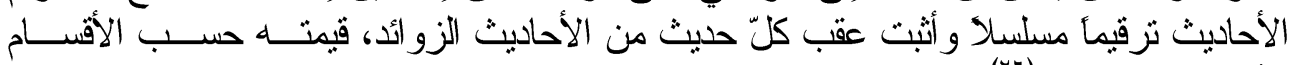

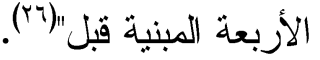

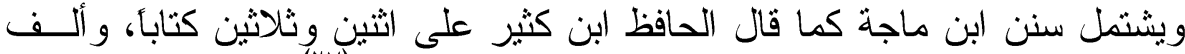

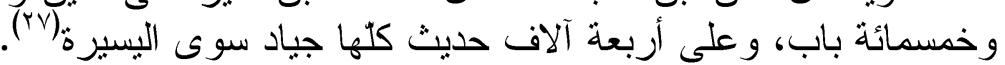

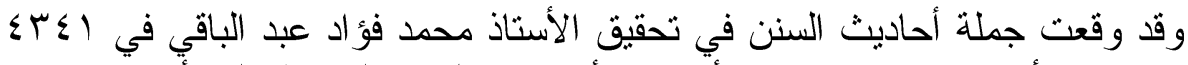

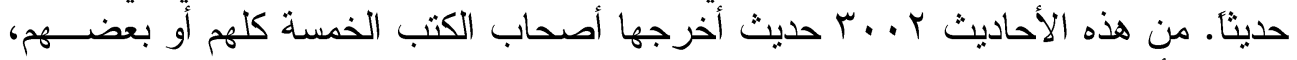

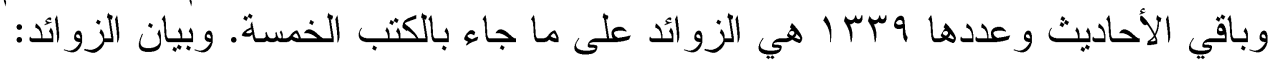

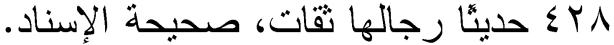
(199 199 ب آ7 حدئًا ضعيفة الإسناد.

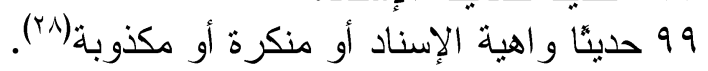

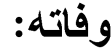

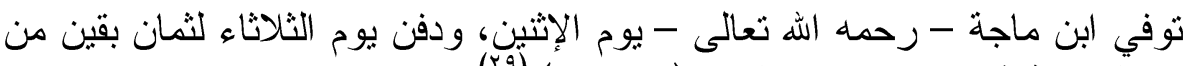

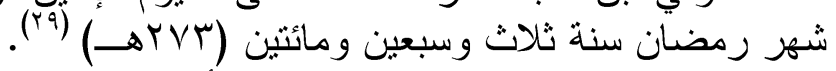

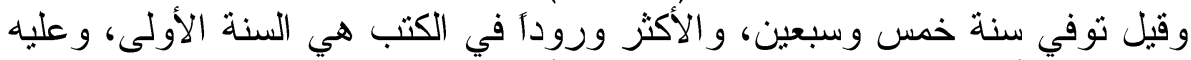

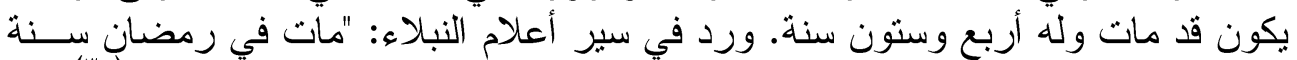

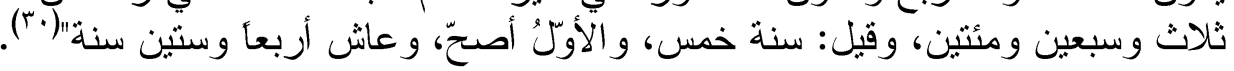




\section{اسم التفضيل}

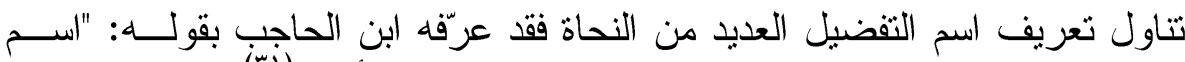

تعريفه:

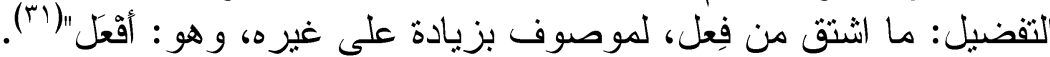

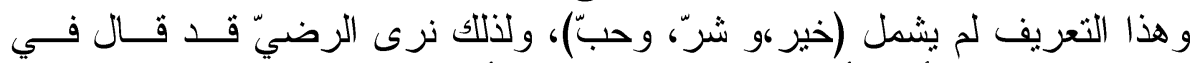

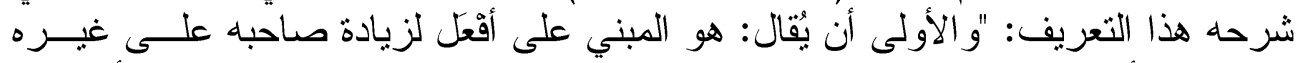

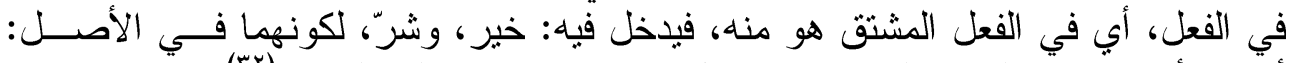

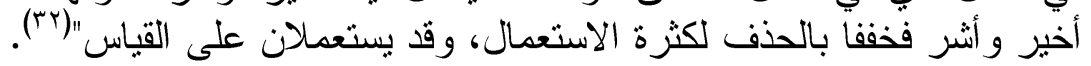

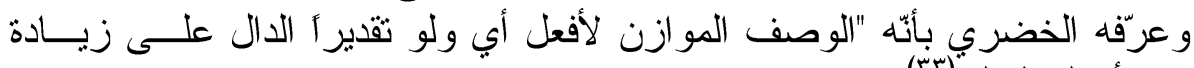

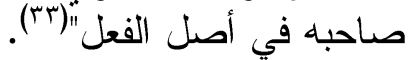

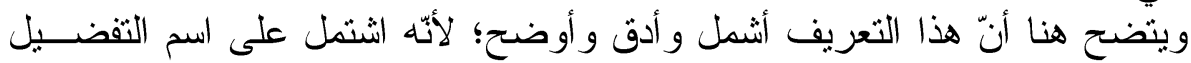

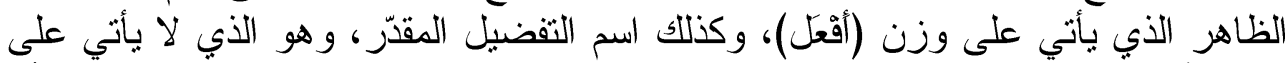

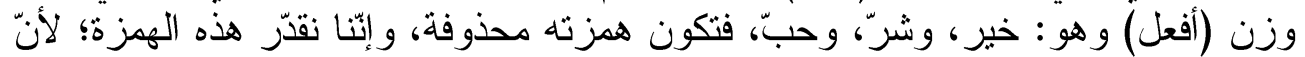

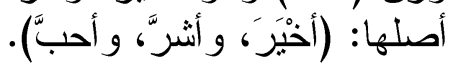

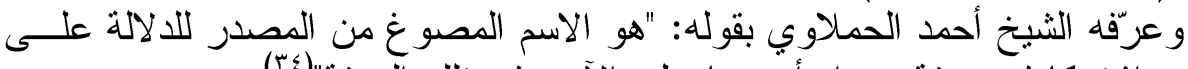

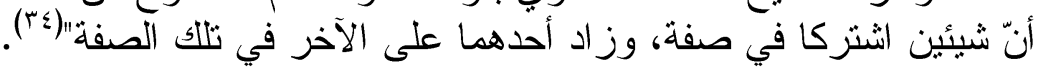

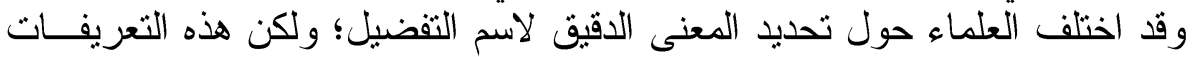

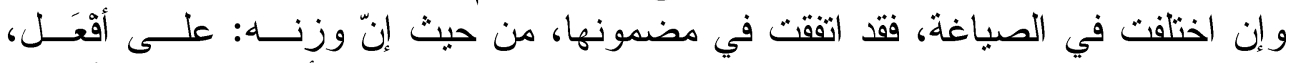

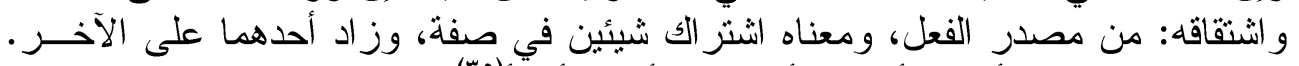

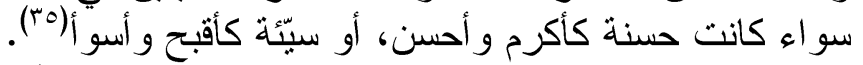

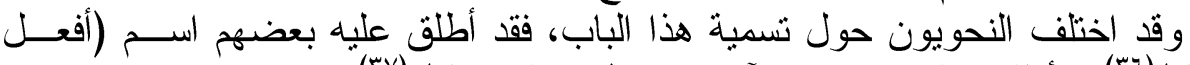

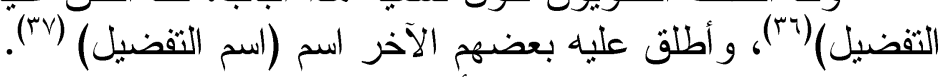

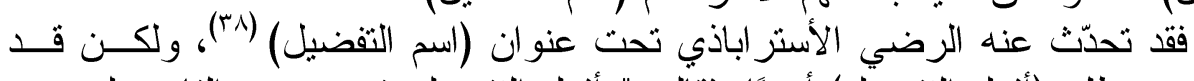

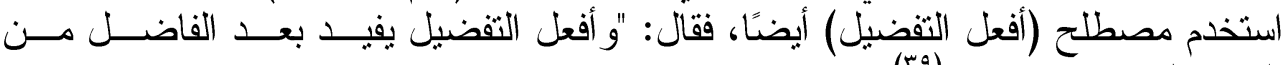

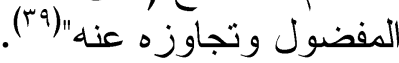

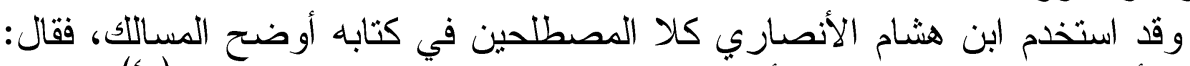

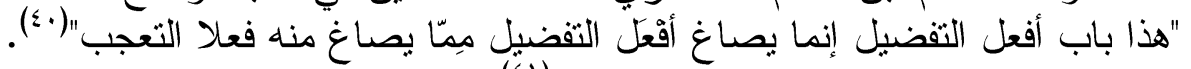

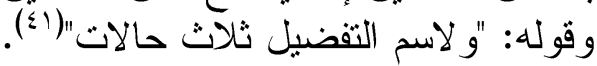

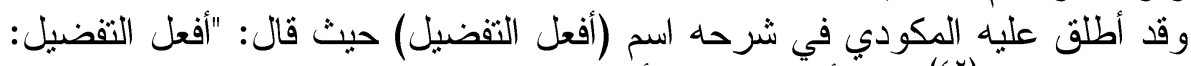

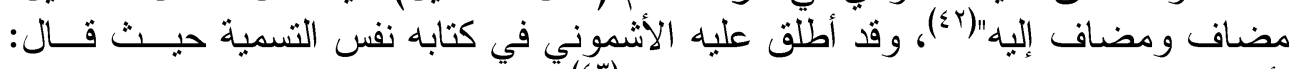

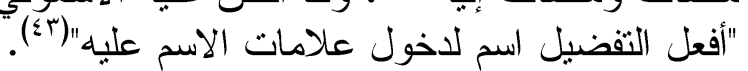

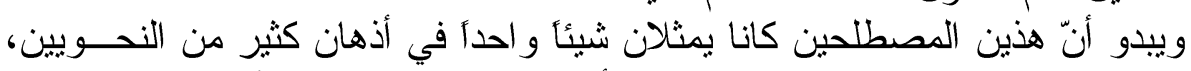

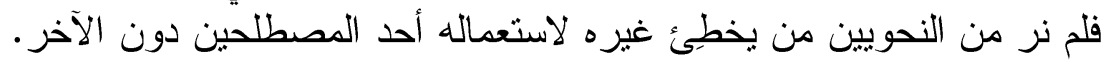

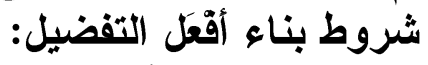

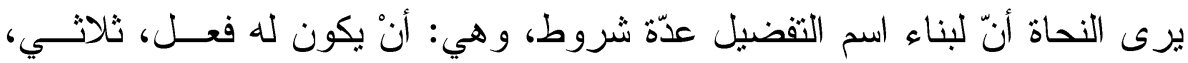

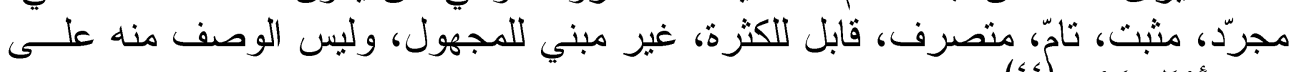

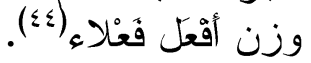


وسنقوم بمناقشتة ثللك الشروط الواردة في كتب النحاة، ثمّ مقارنتها بالو اقع اللغــويّ في سنن ابن ماجة كالآتي:

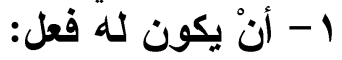

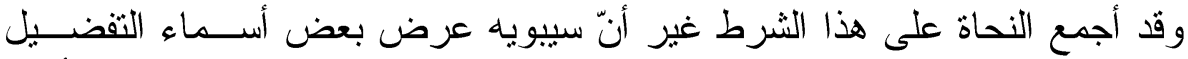

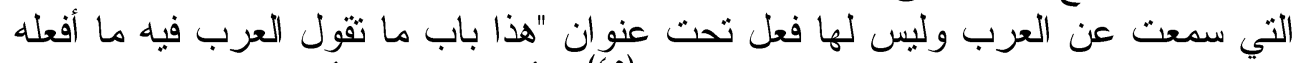

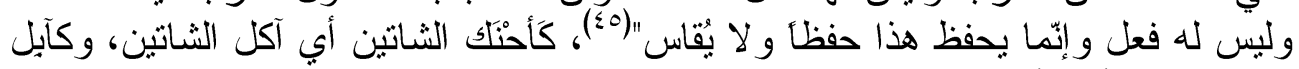

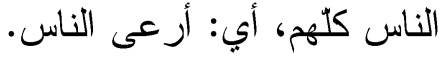

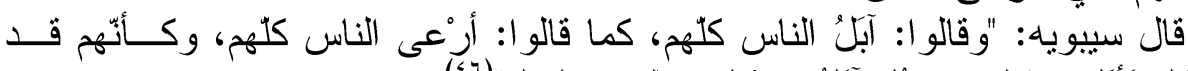

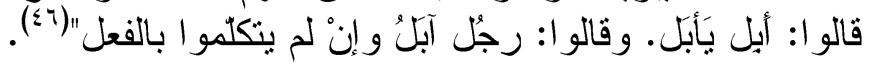

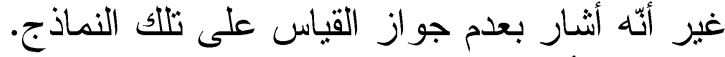

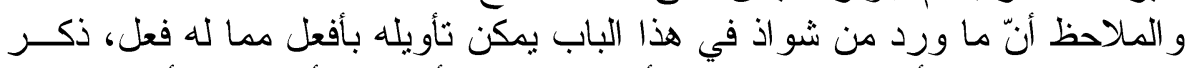

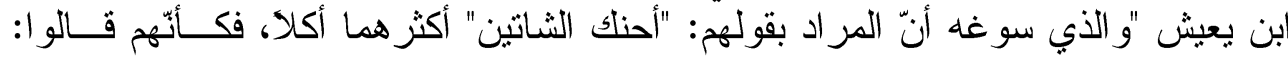

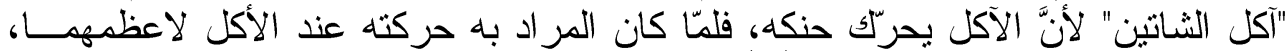

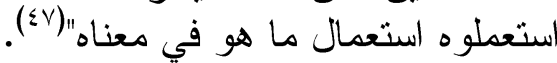

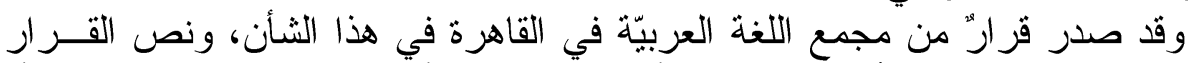

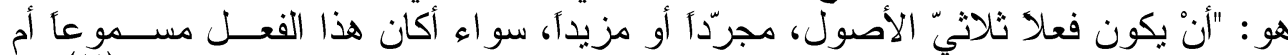

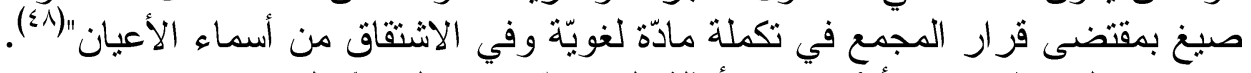

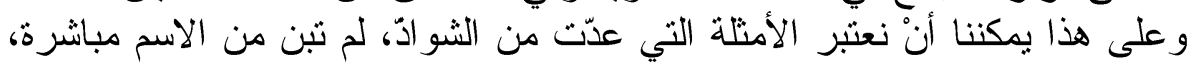

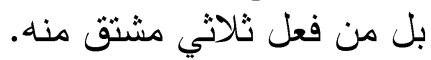

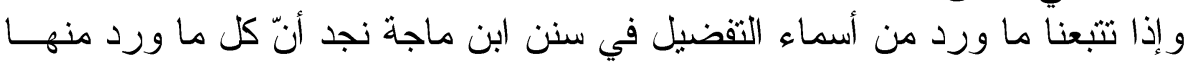

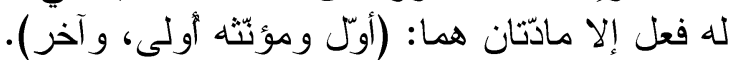

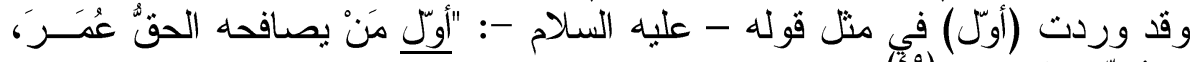

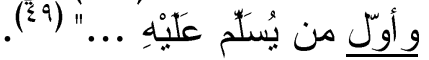

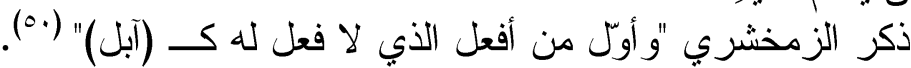

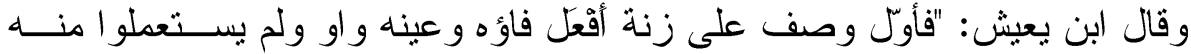

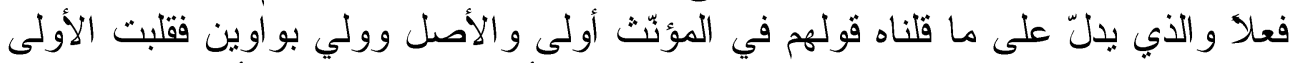

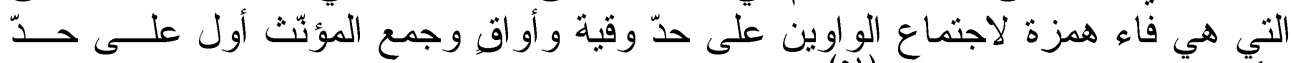

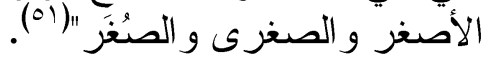

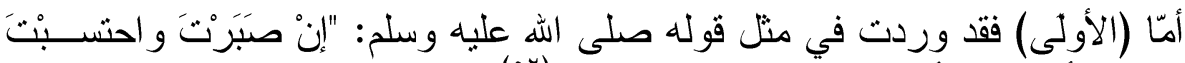

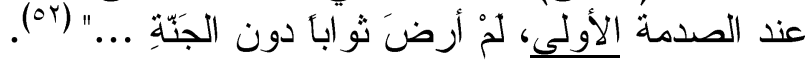

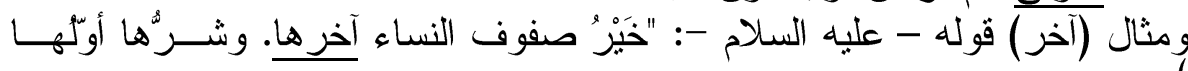
(or) "...

\section{r- أن يكون ثلاثياً:}

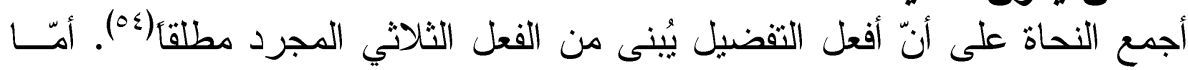

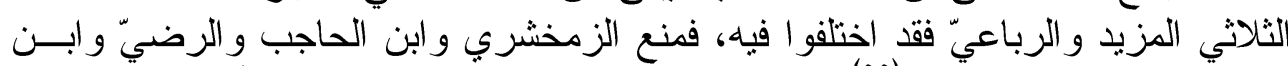

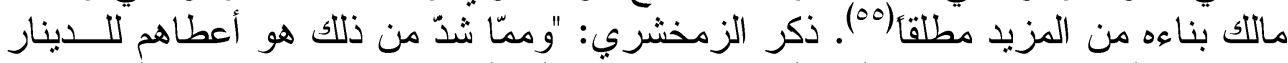

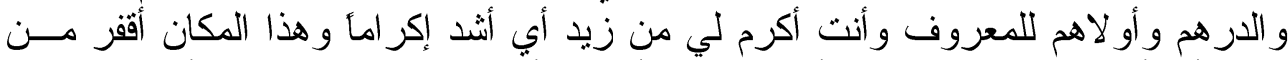

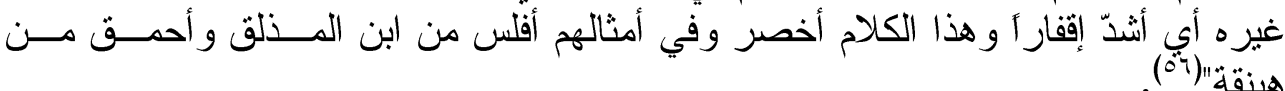




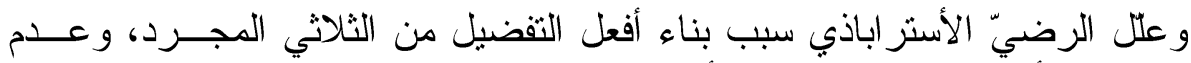

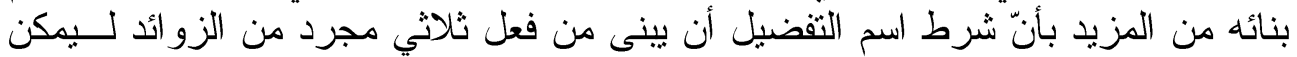

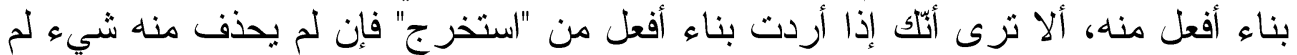

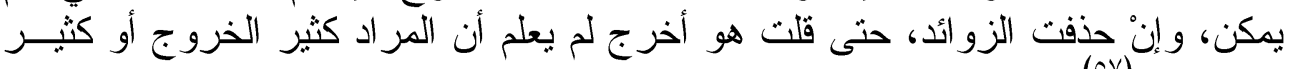

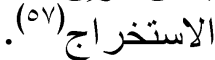

و أجاز سيبويه بناءه من المزيد بالهمزة؛ وذللك لكثرته، نحـــو: أعطــاهم للــدينار،

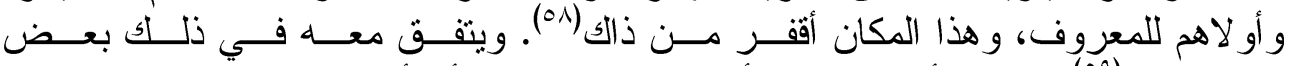

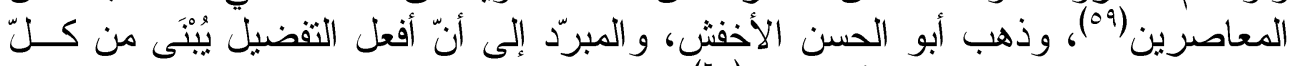

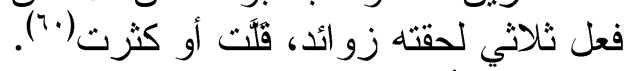

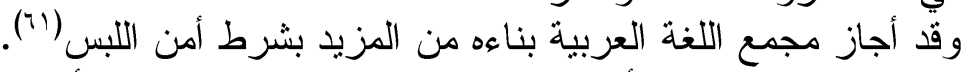

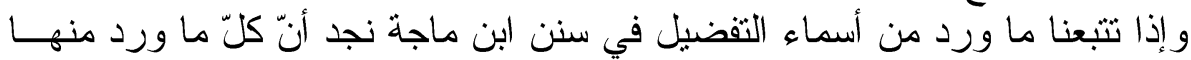

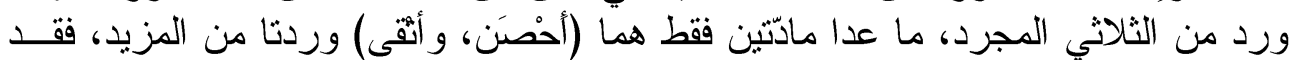

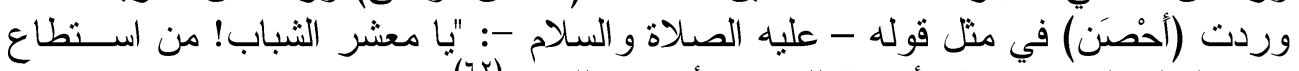

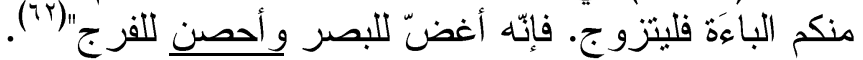

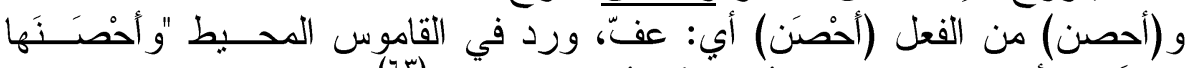

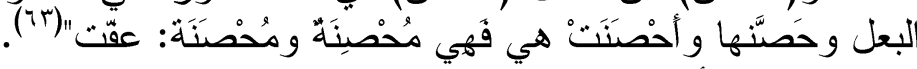

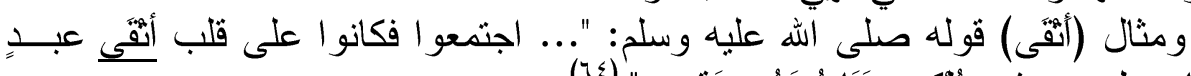

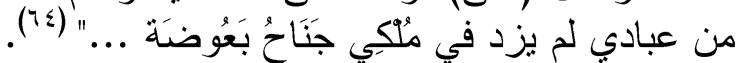

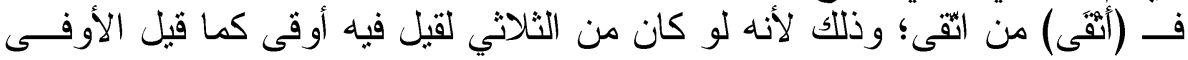
من وفي.

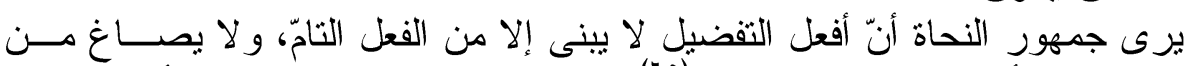

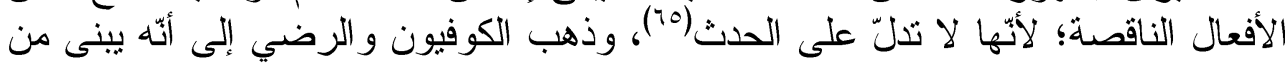

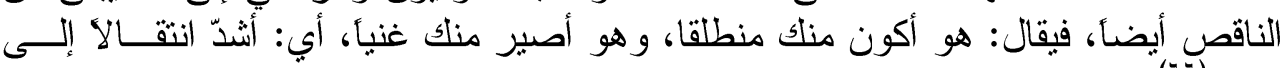

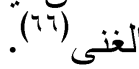

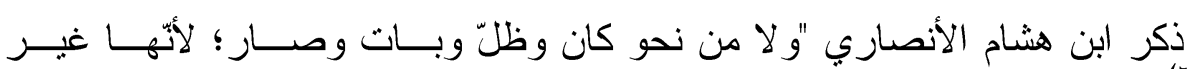

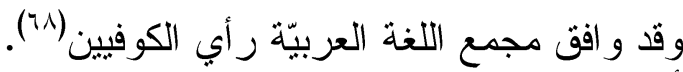

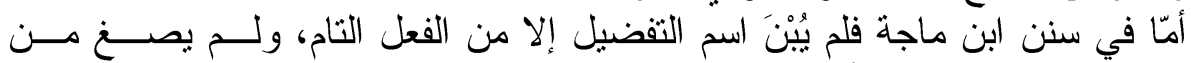

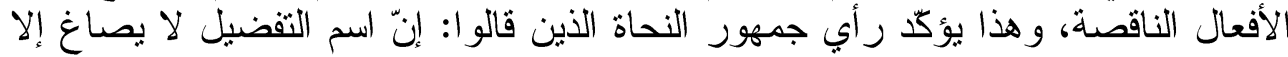
من الفعل التامّ. ع - أن يكون متصرّة أنَّاً:

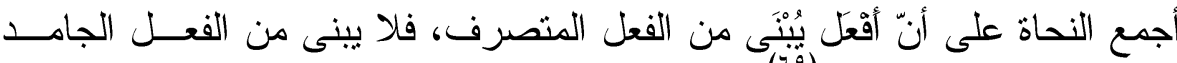

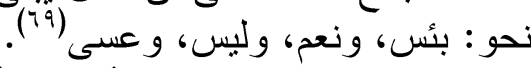

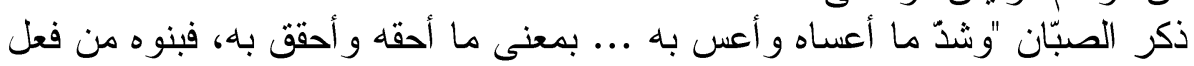

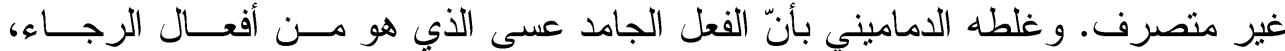

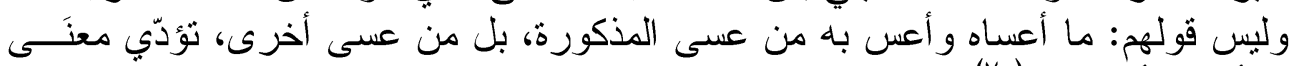

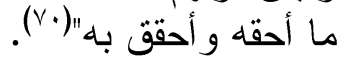
أمّا في سنن ابن ماجة فكلّ ما ورد من أسماء التفضيل ورد من الأفعال المتصرّفة، ولم يأتِ من الأفعال الجامدة مطلقاً. 


\section{ه - أن يكون قابلاً للكثرة أو التفاوت:}

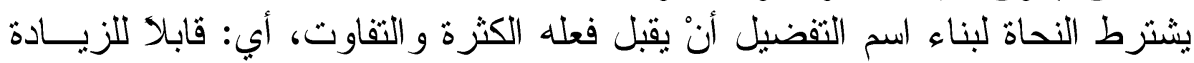

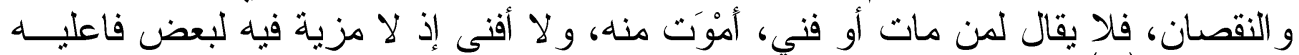
على بعض (v) (v)

ذكر الثيخ أحمد الحمالاوي أن التفاوت يعني التفاضل، والحدث غير القابل للتفاوت

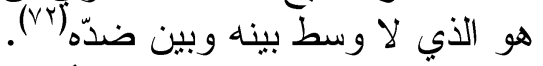
وُفي سنن ابن ماجة نجد أنّ كلّ أسماء التقضيل الواردة فيه قابلة للكثرة و التقــاوت،

$$
\text { أو التقضيل المطلق. }
$$

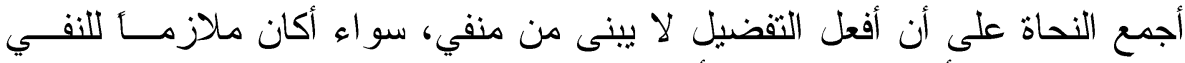

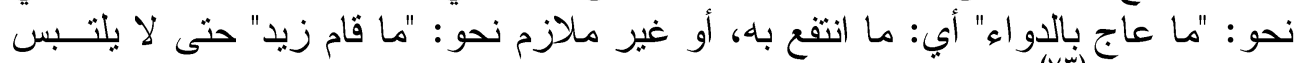

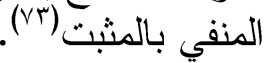
أمّا في سنن ابن ماجة فكلّ ما ورد من أسماء التفضيل وردت بالإثبات، ولم تـرد بالنفي، وهذا يؤكد قول النحاة.

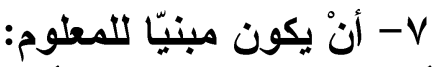

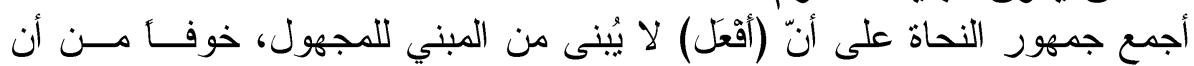

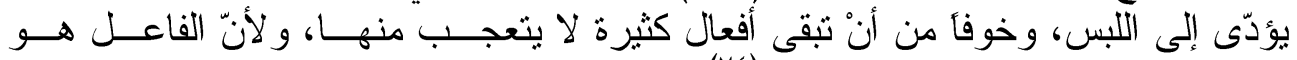

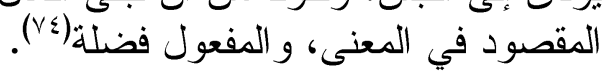

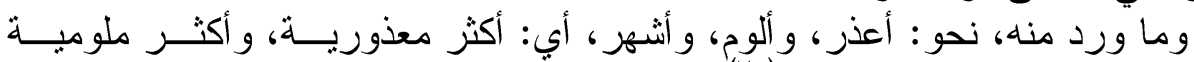

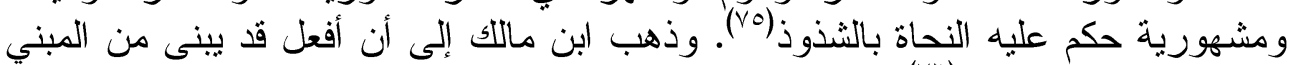

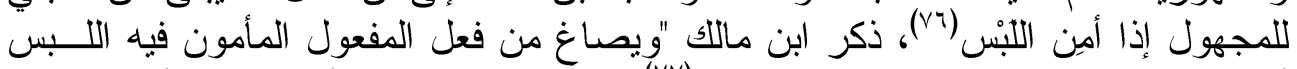

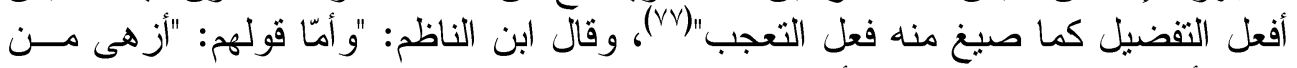

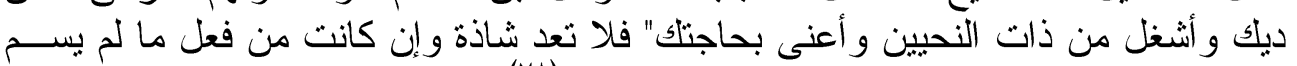

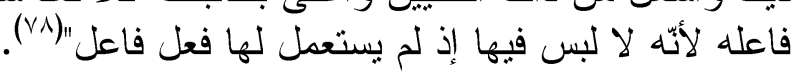

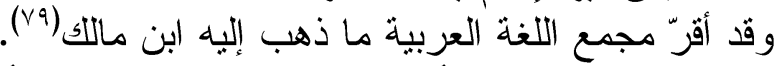

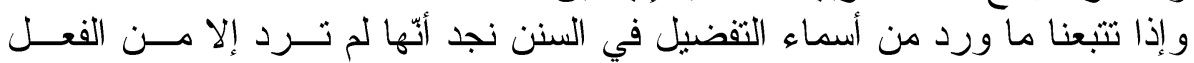

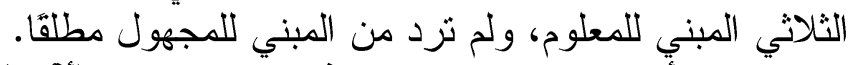

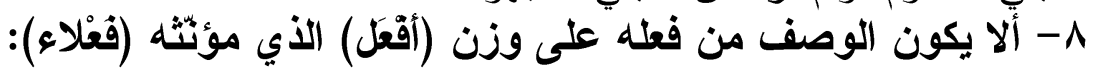

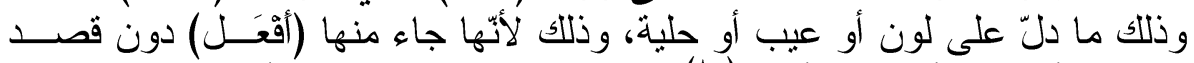

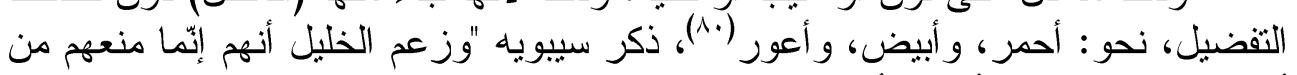

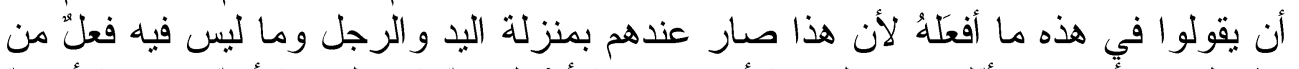

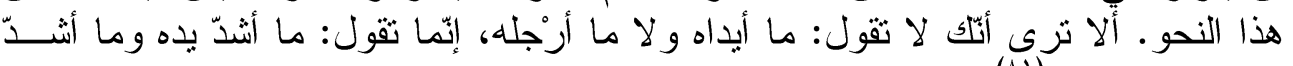

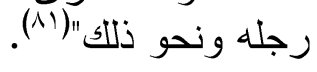

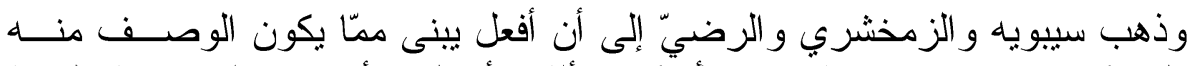

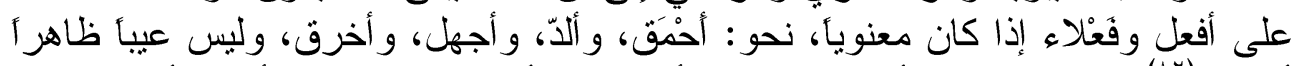

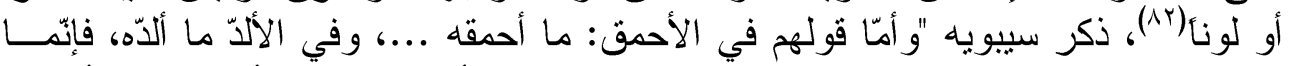

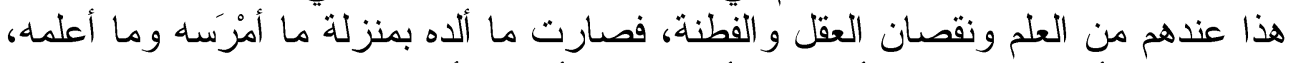

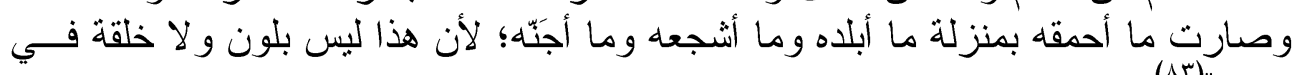




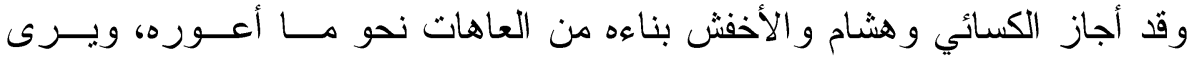

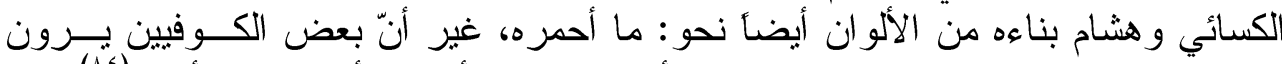

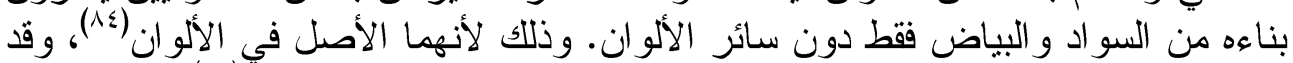

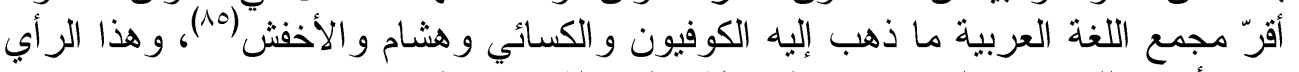

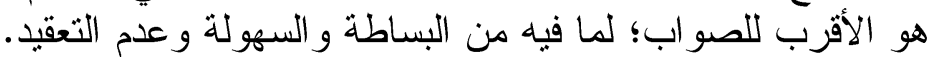

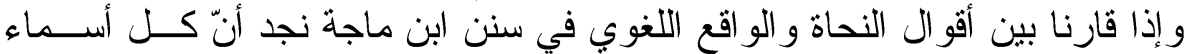

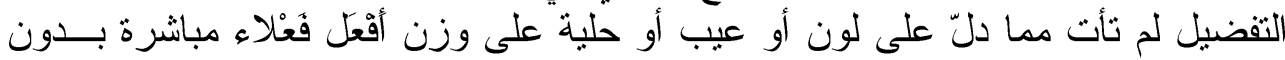

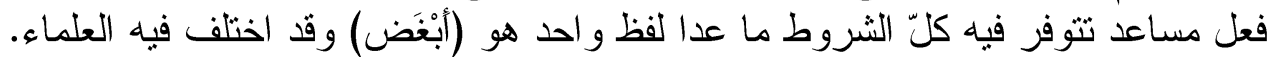

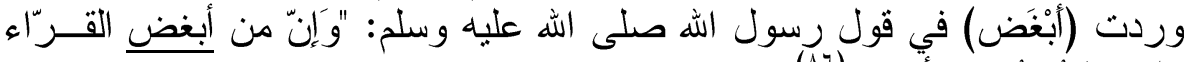

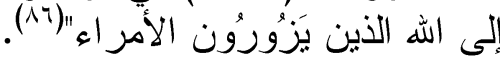

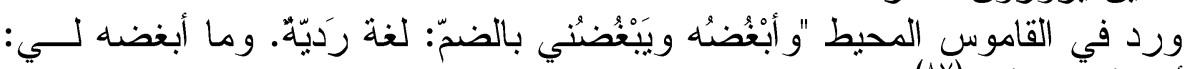

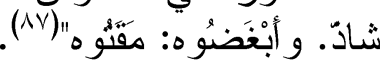

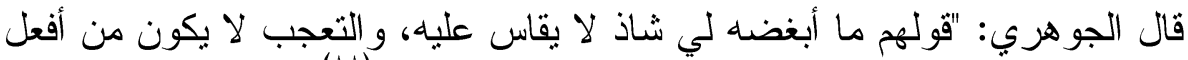

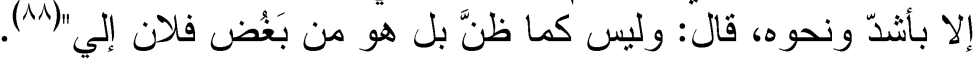

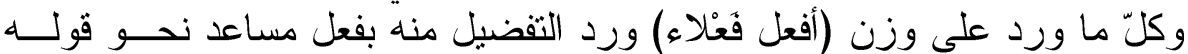

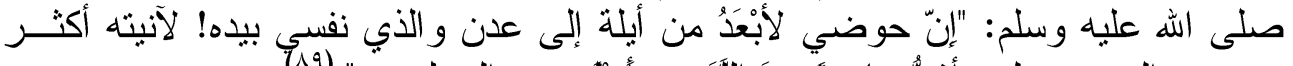

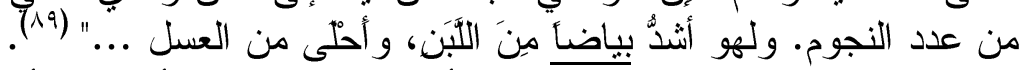

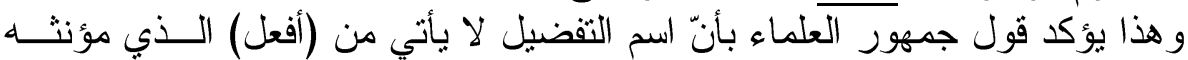

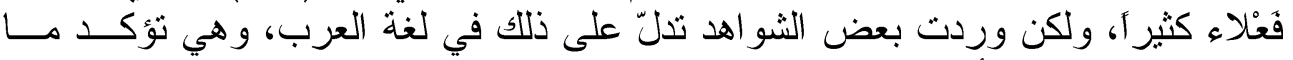

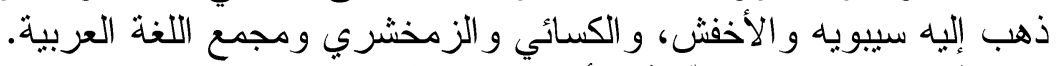

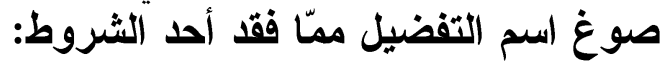

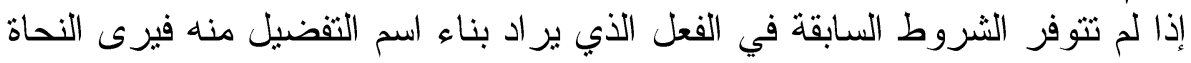

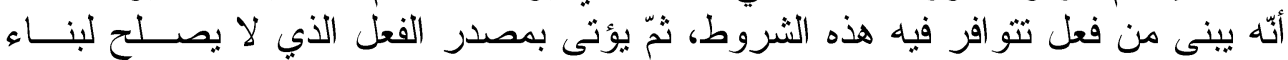

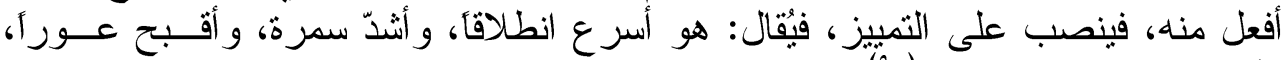

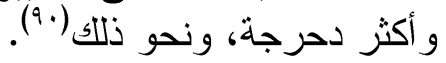

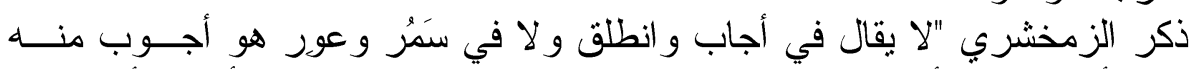

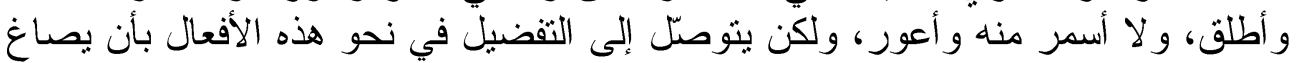

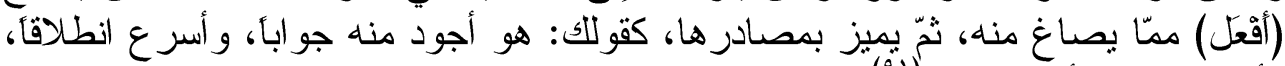

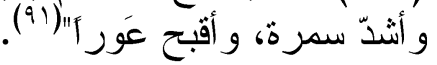
وكذا المنفي و المبني للمجهول إلا أنّ مصدر ها يكون مؤوّلا لا صريحا نحــو : مـــا

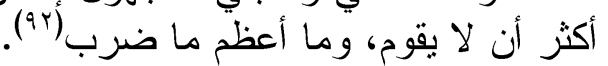

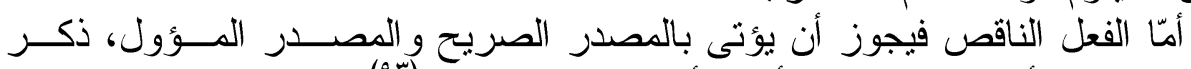

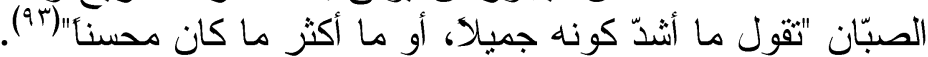

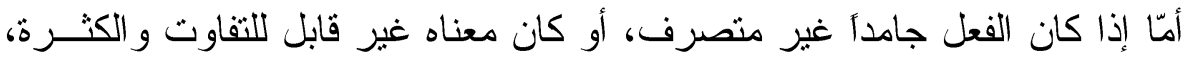

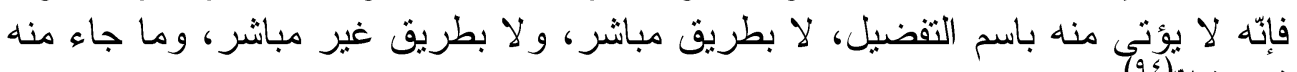

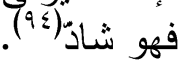

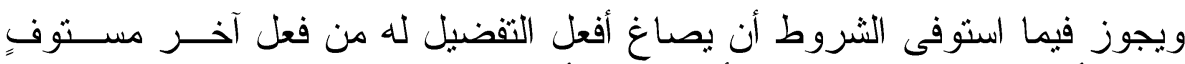

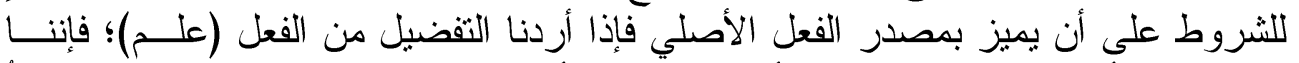

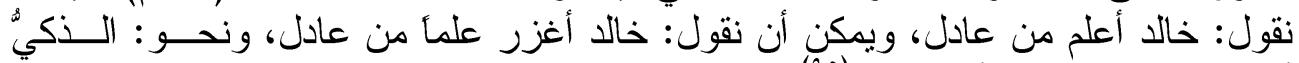

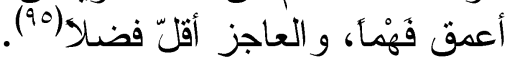




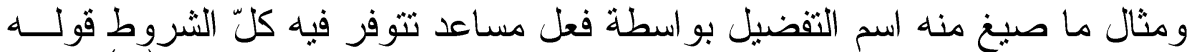

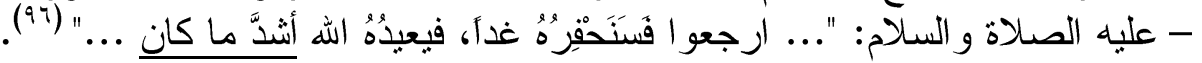

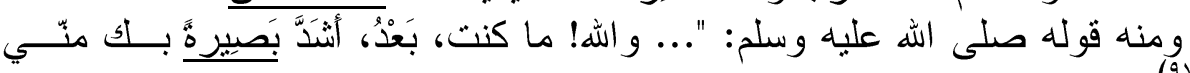

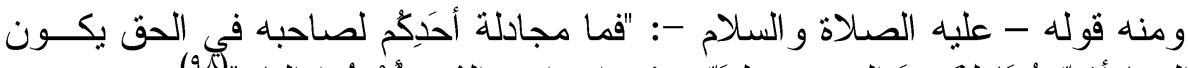

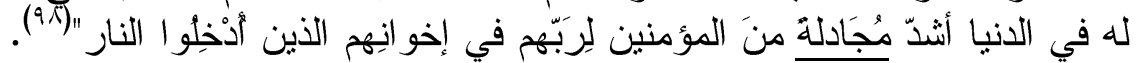
بناء اسم التفضيل على وزن (قُعْل):

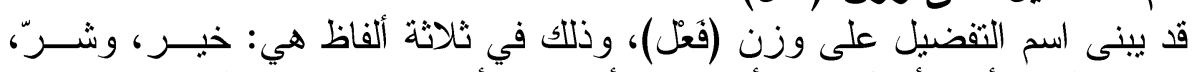

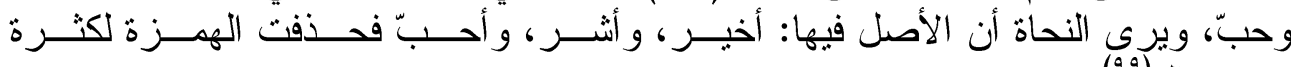

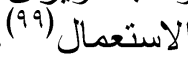

وقال الأخفش حذفت لأنهما لما لم يشتقا من فعل خولف، فعلى هذا فيهما شـذوذان

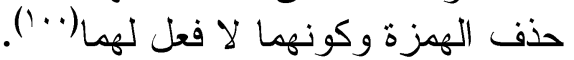

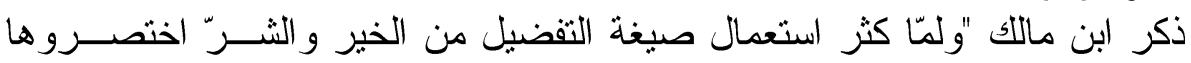

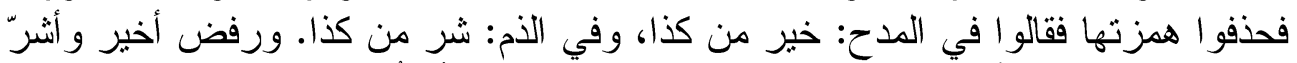

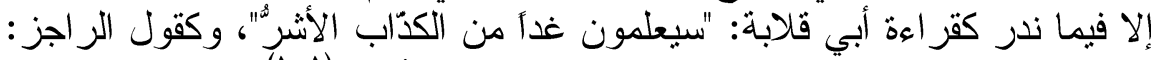

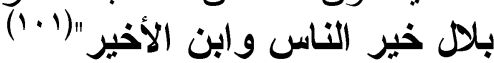

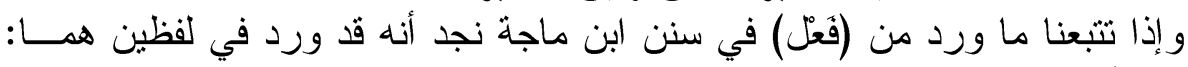

فقد وردت خير في مثل قوله صلى الله عليه وسلم: "إنّ هذا الشهر قد حضركم وفيه

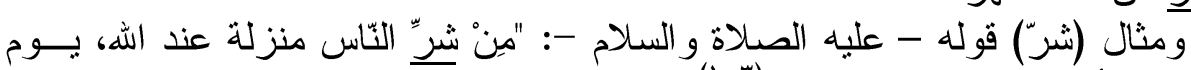

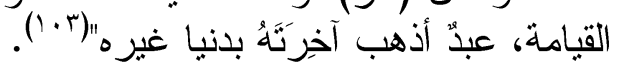
ولم ترد (خير) على الأصل بزيادة الهمزة أي (أخير) مطلقاً في السنن.

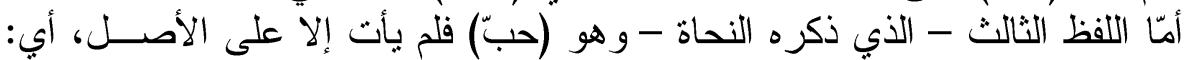

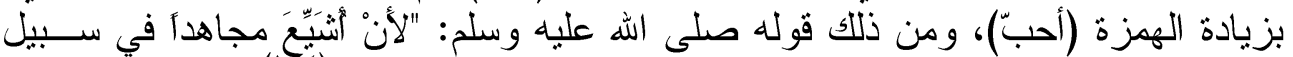

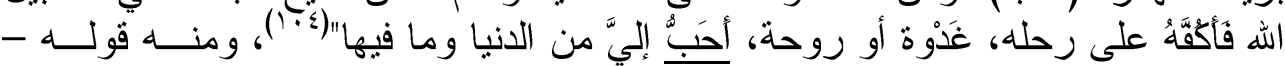

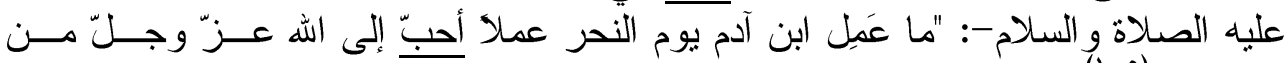

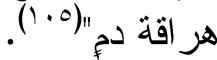

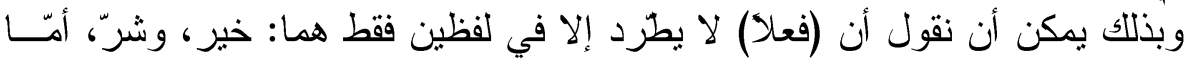

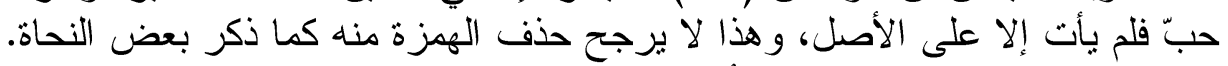

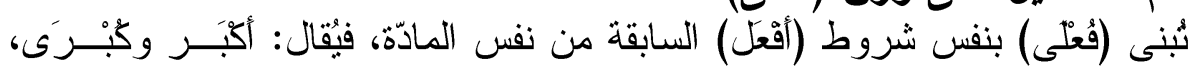

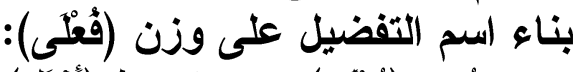

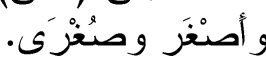

ويشترط لبنائها أن تعرّف أو تضاف، فلا يقال: عظمى، وفُضْْـلـى، ولكــن يقــال:

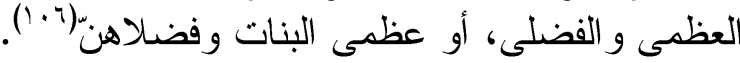

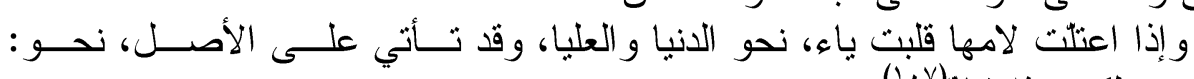

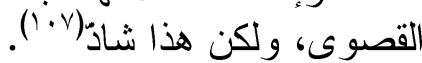




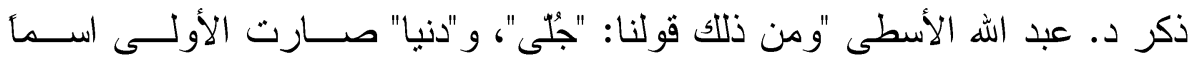

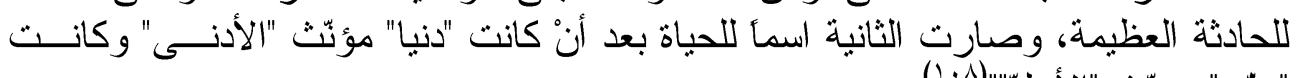

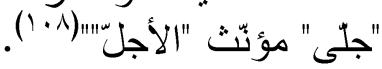

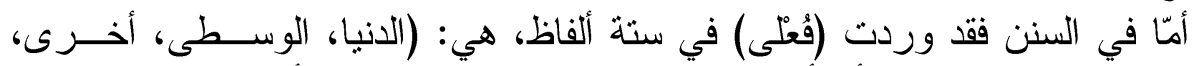

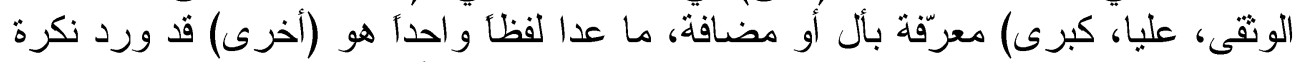

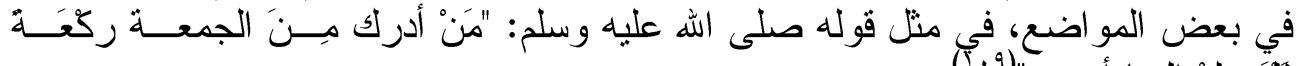

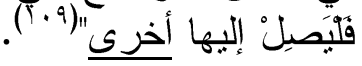

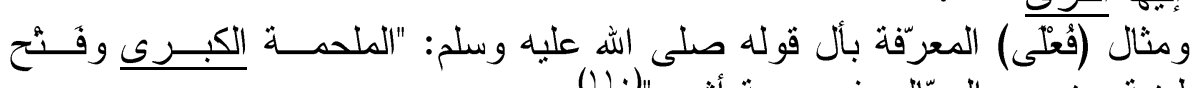

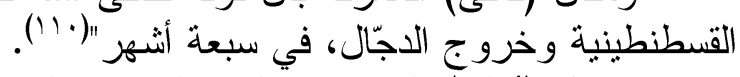

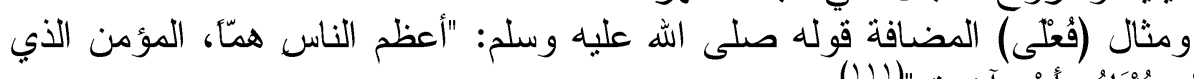

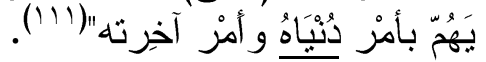

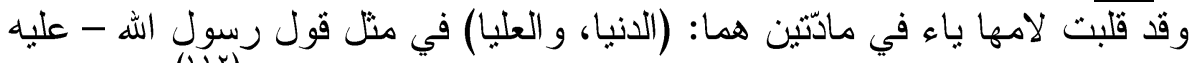

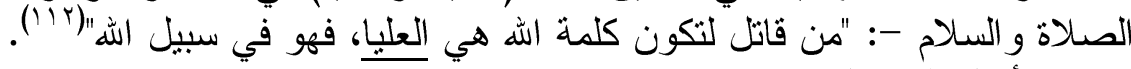

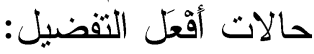
و لاسم التفضيل باعتبار اللفظ ثلاث حالات، وهي:

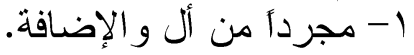

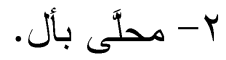

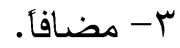

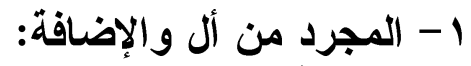

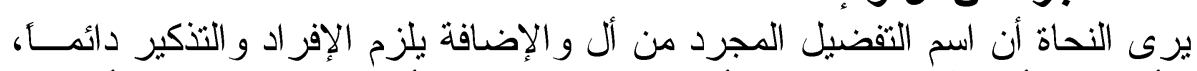

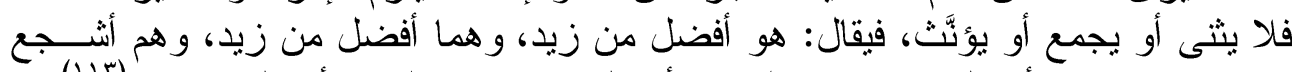

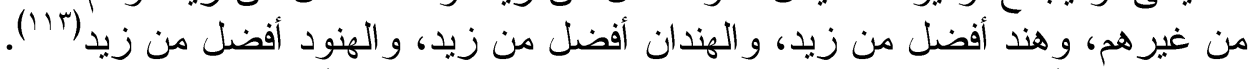

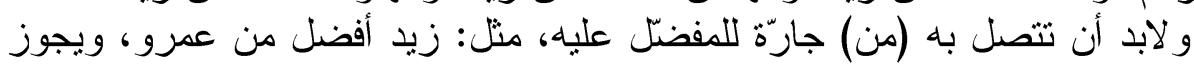

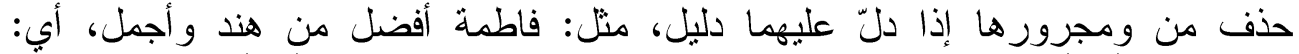

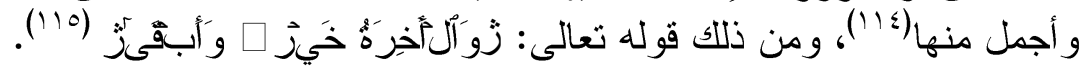

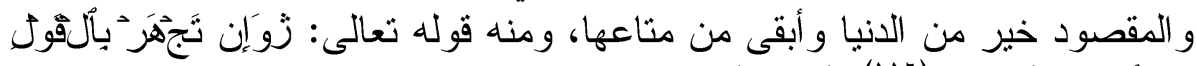

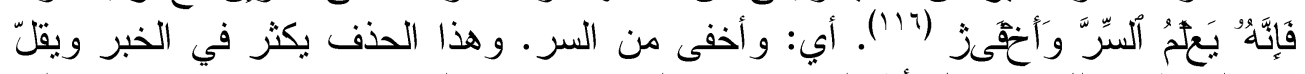

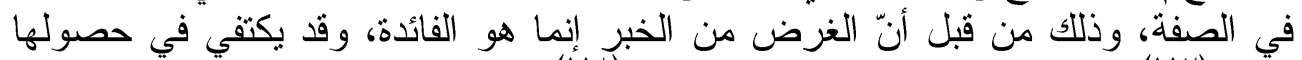

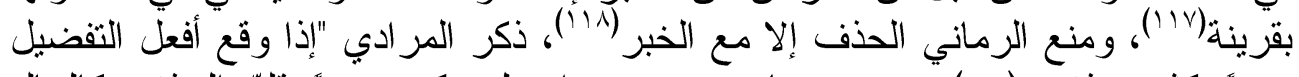

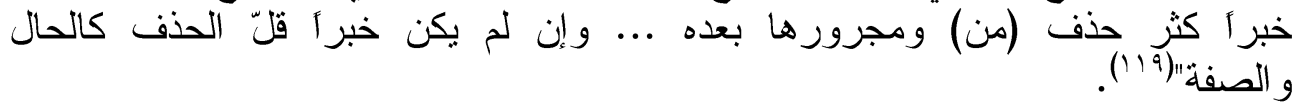

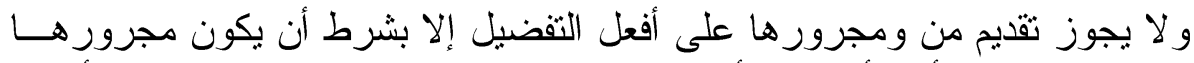

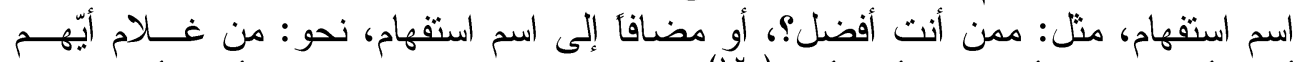

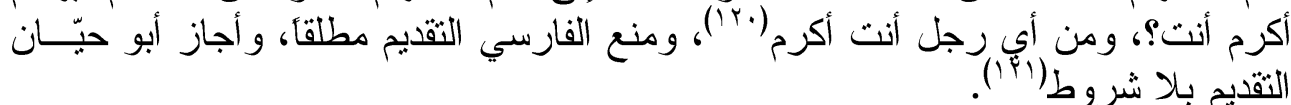

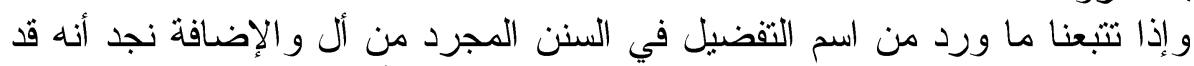

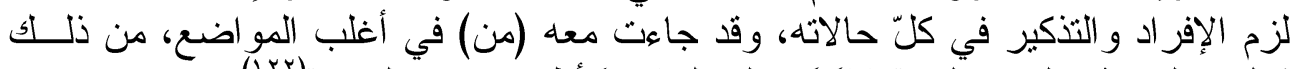

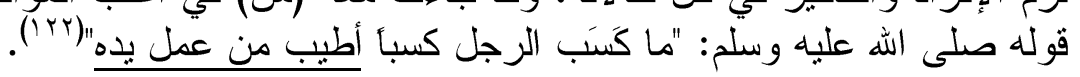




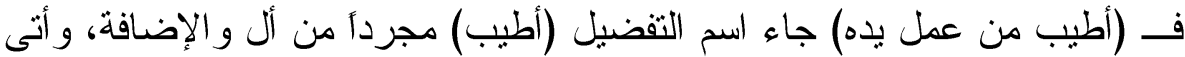

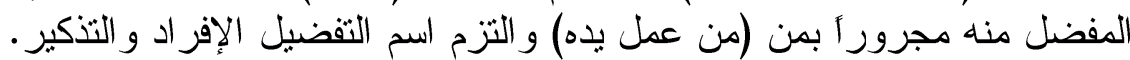

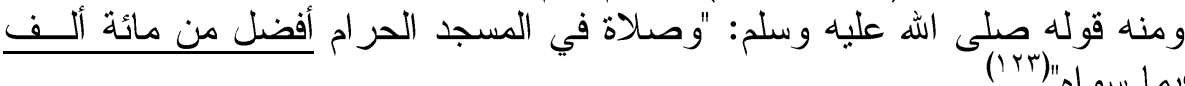

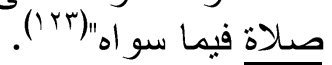

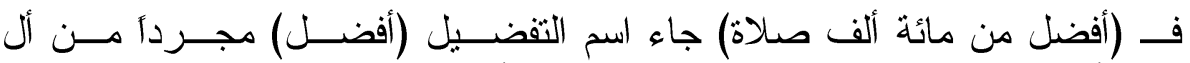

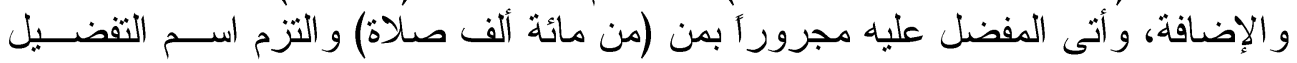

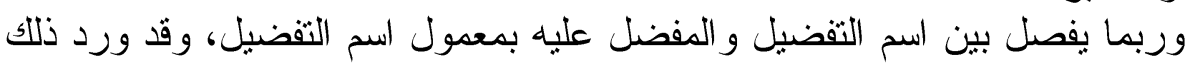

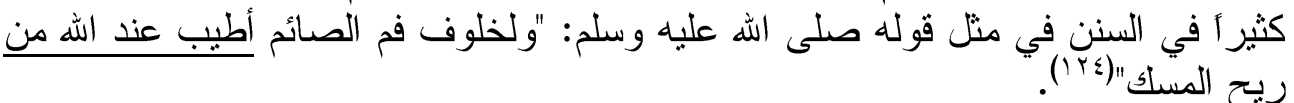

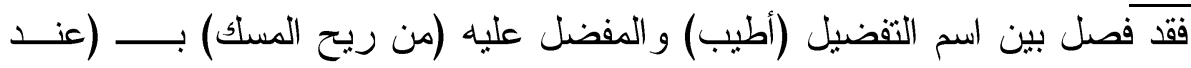
وقد حذفت من ومجرورها لدلالة السياق عليها في منل قوله صله الهى الله علبه وسلم:

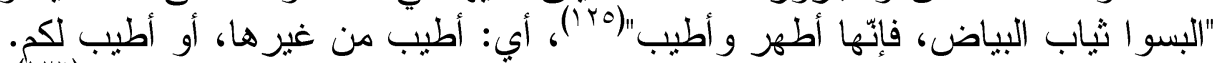

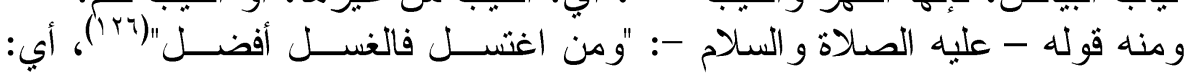
أفضل من عدمه. ولم تثقدم من ومجرور ها على أفعل التفضيل في السنن مطلقاً.

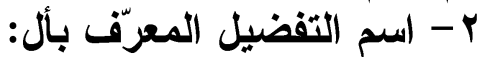

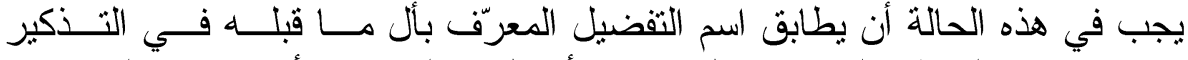

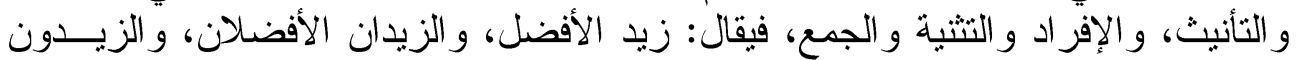

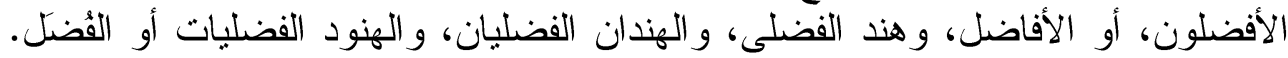
و لا يجوز أن تتصل به (من) جارّة للمفضّل عليه، فلا يقال: زيد الأفضل من عمرو، أمّـــا.

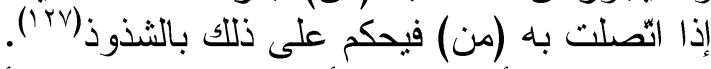

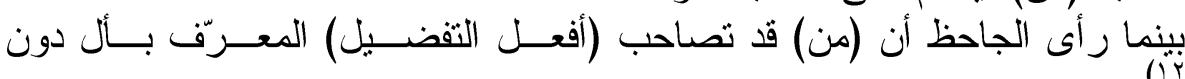

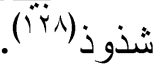

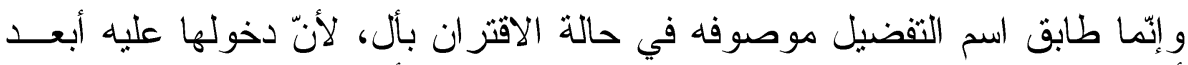

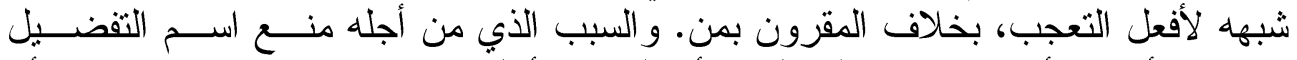

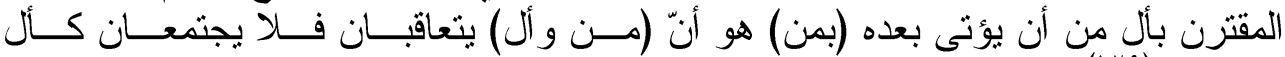

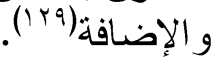

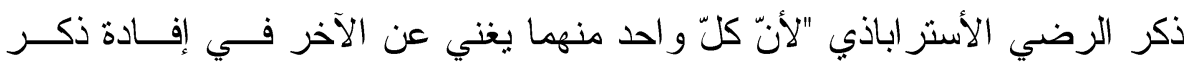

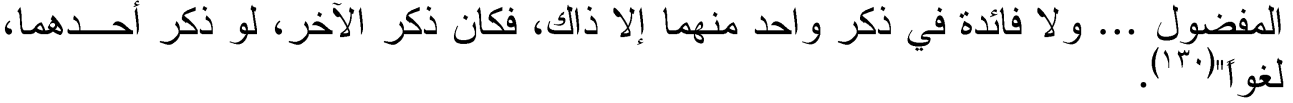

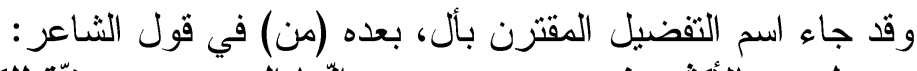

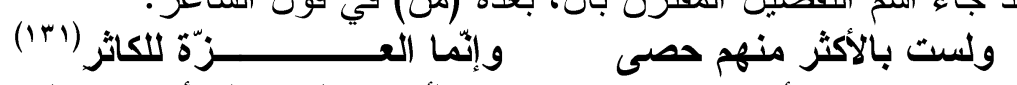

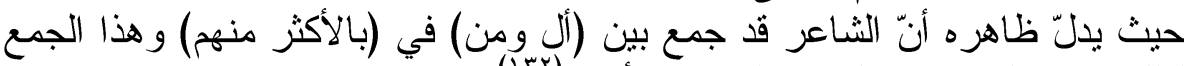

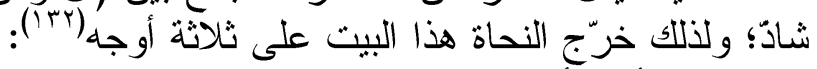

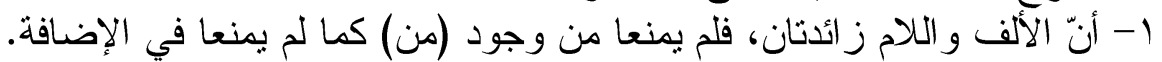

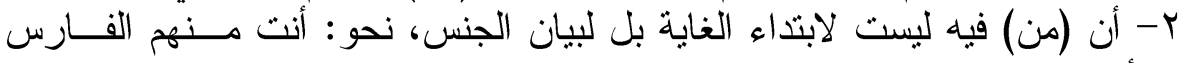
و الشجاع: أي من بينهم. 


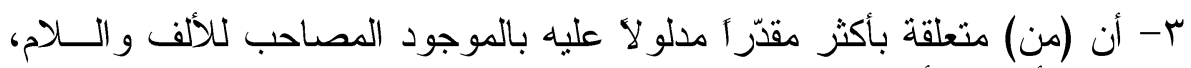

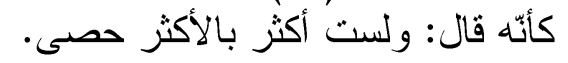

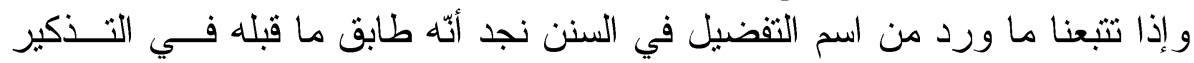

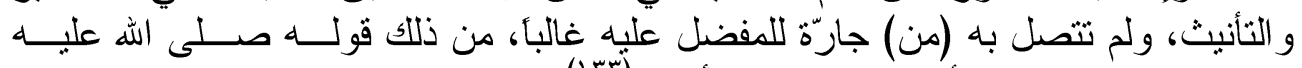

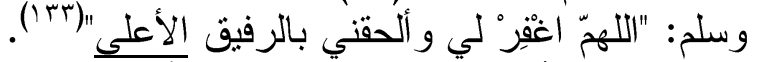

فـ (الأعلى) اسم تفضيل محلّى بأل فوجب مطابقته لما قبله في النوع و العدد.

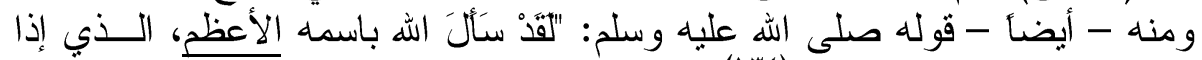

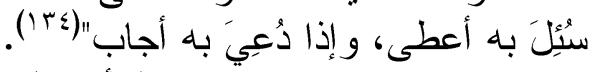

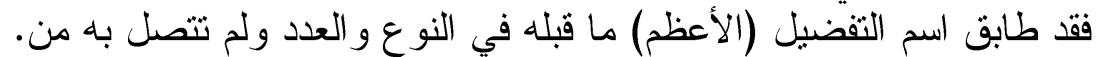

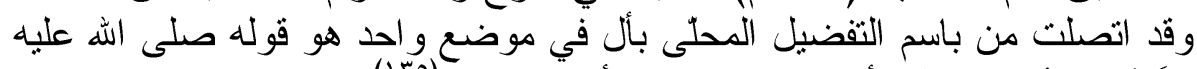

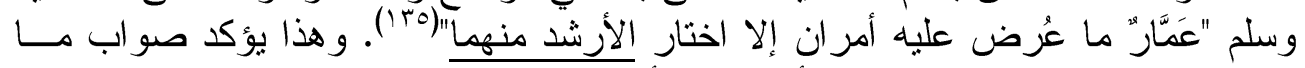

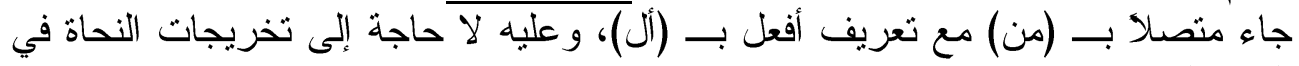

ب- اسم التفضيل المضاف: البيت السابق.

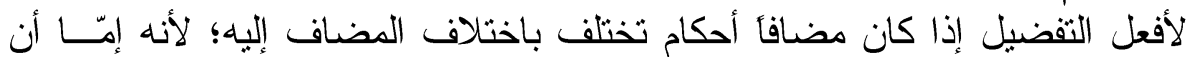

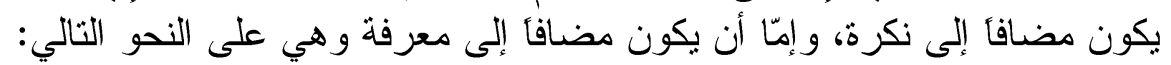

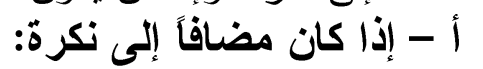

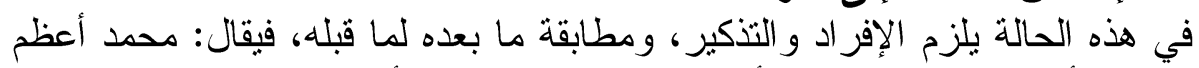

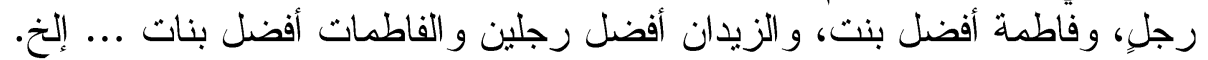

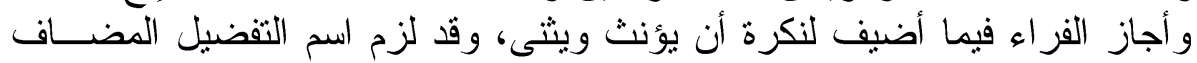

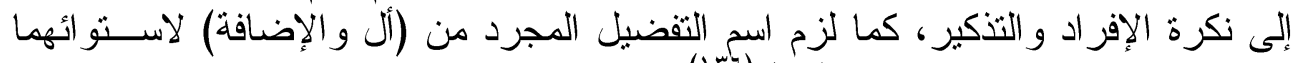

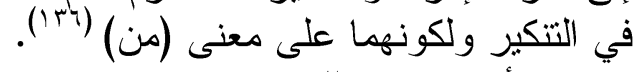

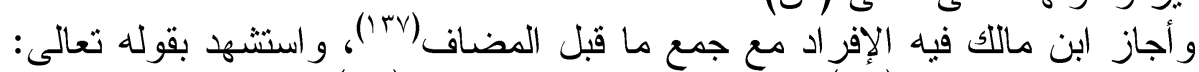

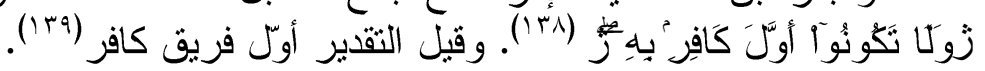

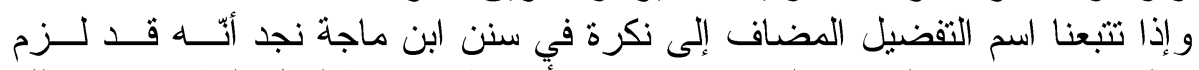

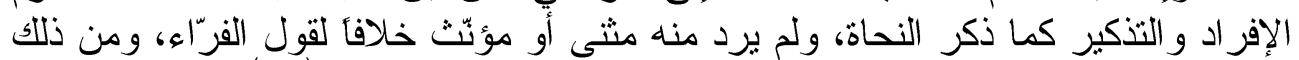

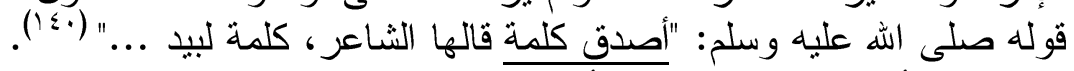

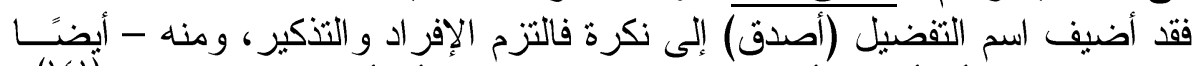

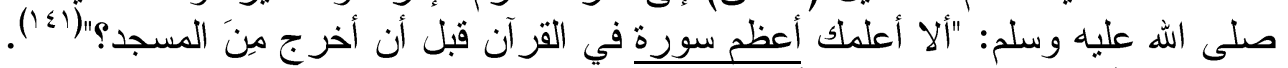

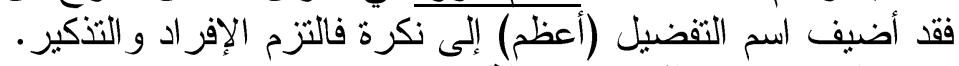

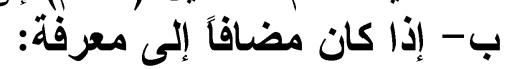

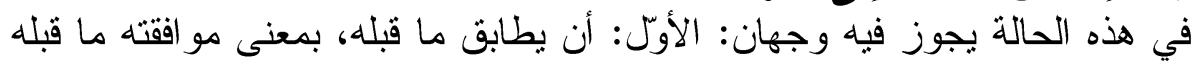

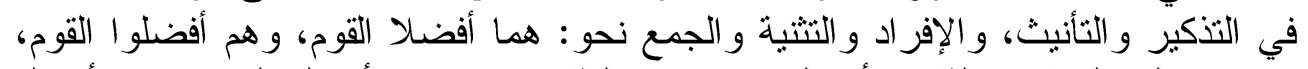

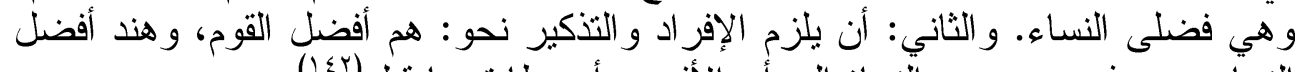

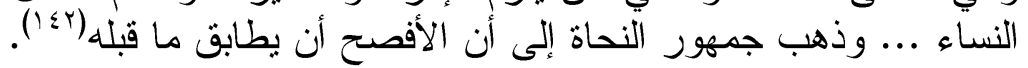

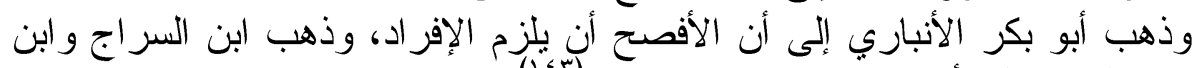

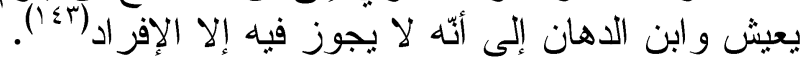

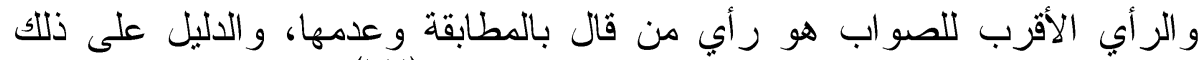

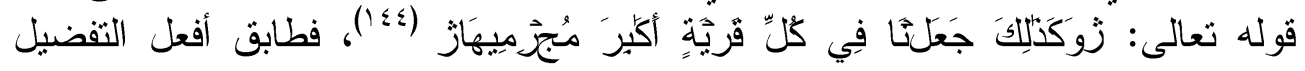


موصوفه، و الموصوف محذوف تقديره (قومأ أكابر)، ولم يقل: (أكبر مجرميها)، ومن عدم

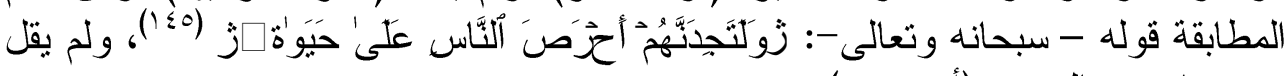

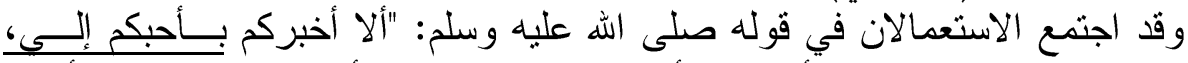

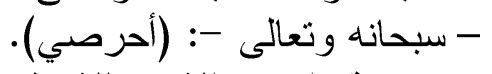

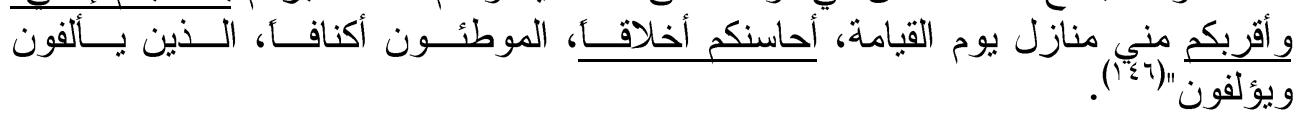
ولذلك أرى أيّه يجوز المطابقة وعدمها، و الدليل على ذلك ورود أمثلة الوجهين في القرآن و السنة، و الشعر المحتج به.

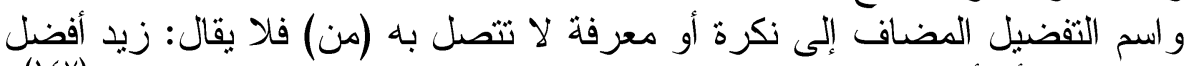

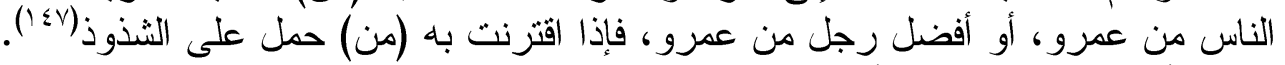

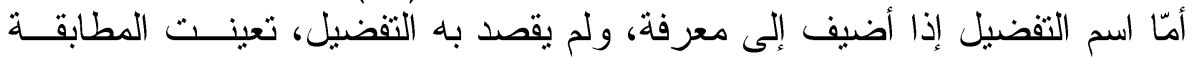

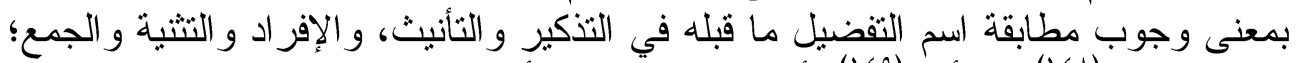

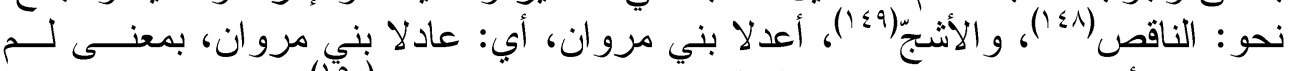

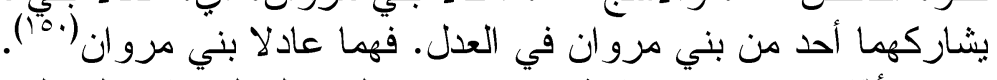

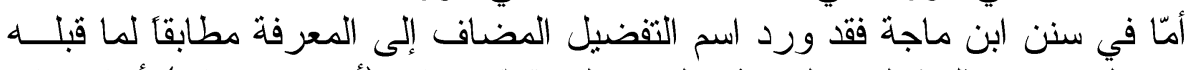

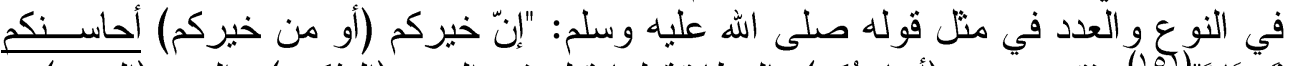

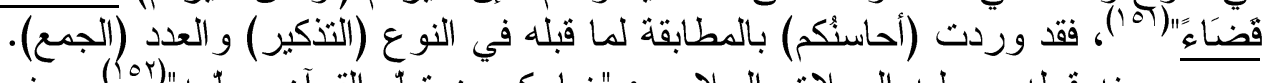

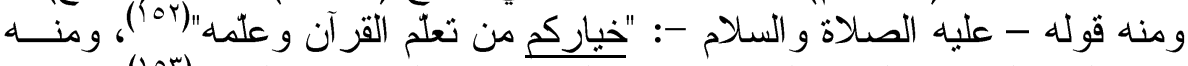

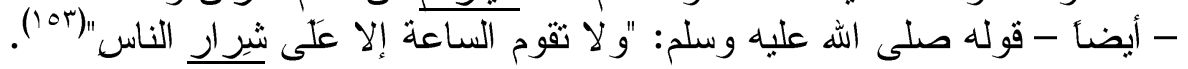

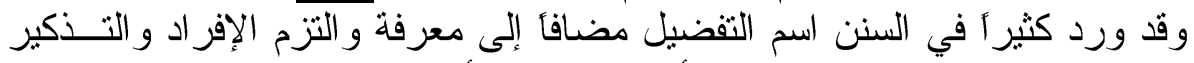

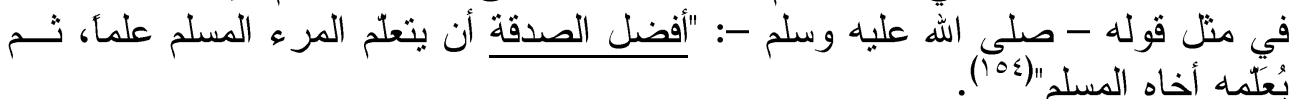
فقد أضيف اسم التفضيل (أفضل) إلى معرفة (الصدقة) معرّفأ بالألف و اللام فالتزم

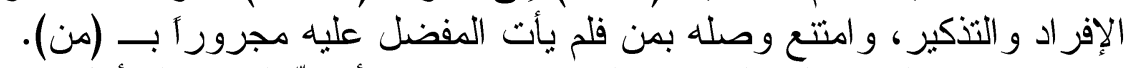

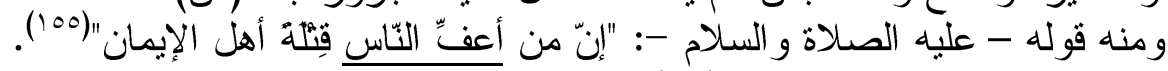

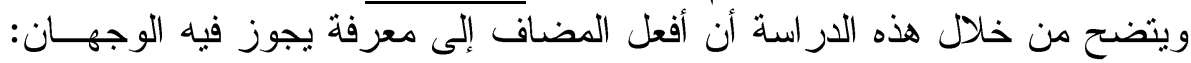

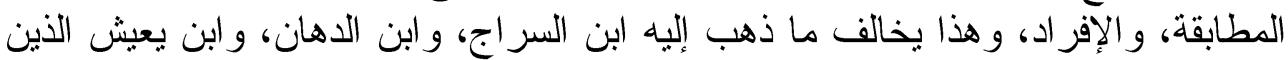

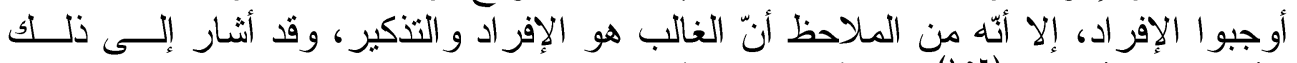

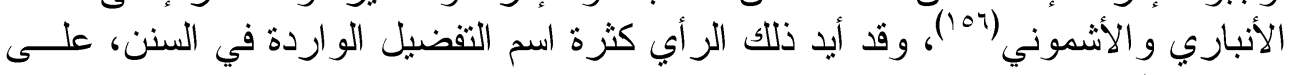
الإفر اد و التذكير · و الإنيون

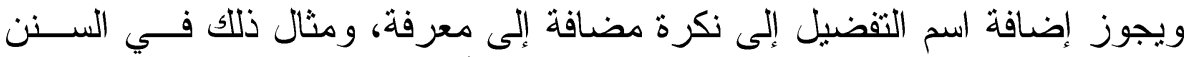

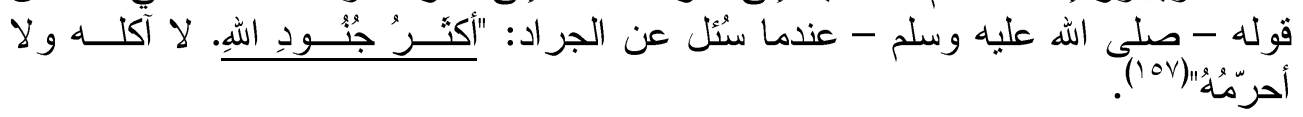

فاسم التفضيل (أكثر) مضاف إلى نكرة مضافة إلى معرفة، وتسمى هذه الإضــــافة

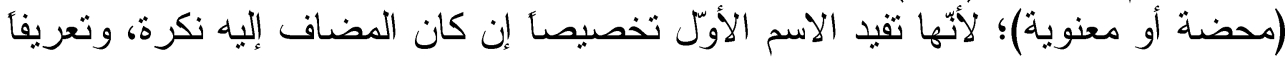

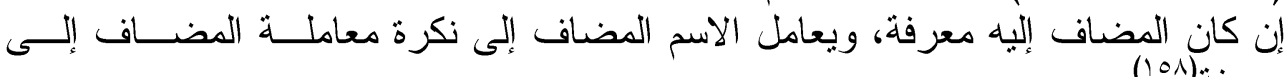
ونلاحظ في هذه الدر اسة أنّ اسم التفضيل المضاف إلى معرفة أكثر ورودأ من اسم التفضيل المضاف إلى نكرة. 


\section{دلالة اسم التفضيل}

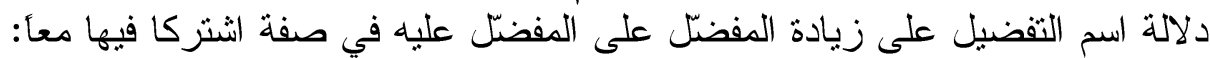

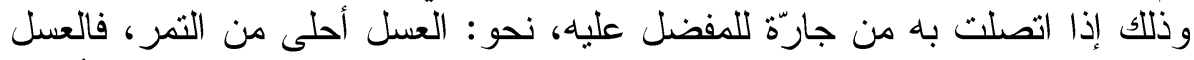

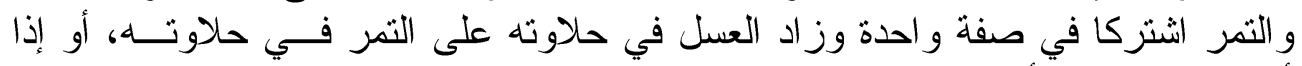

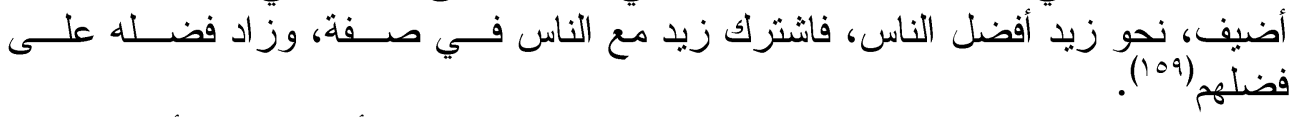

ذكر ابن ماللك "و لابد من اثتر الك المفضول و الفاضل فيما أفعل منه إلا أنّه لا يقــال

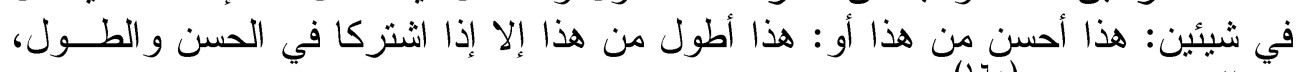

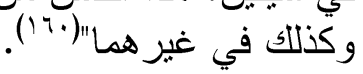

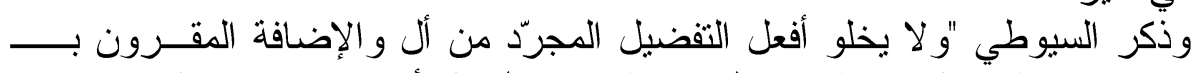

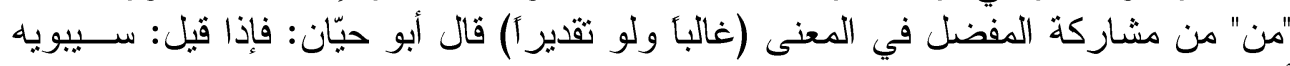

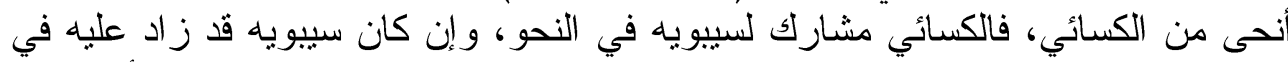

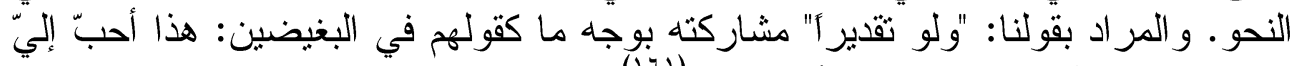

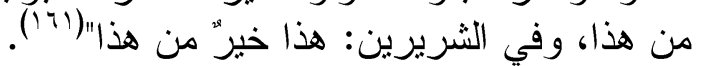

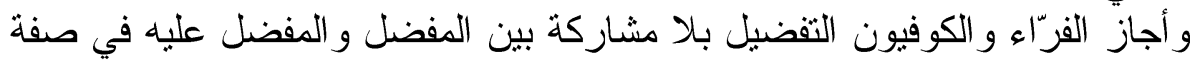

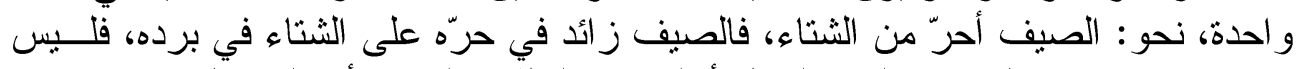

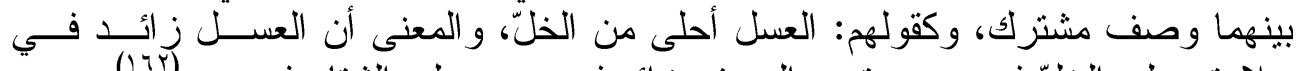

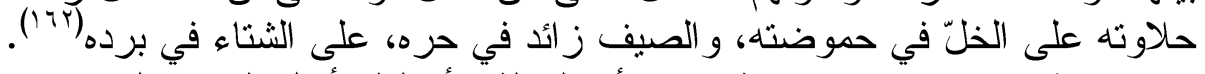

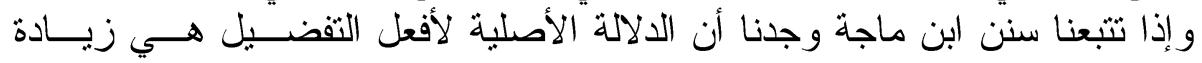

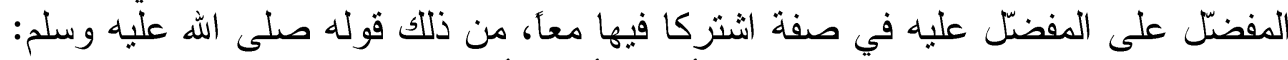

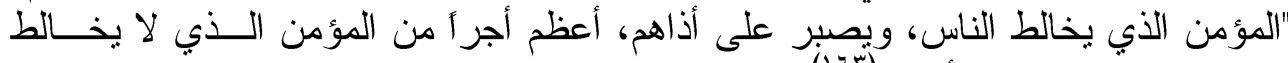

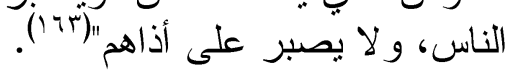

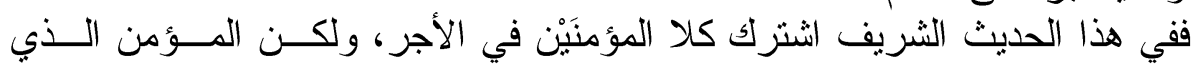

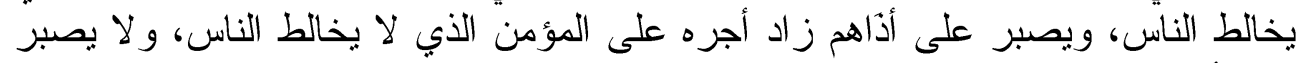
ومثال المضاف قوله صلى الله عليه وسلم: "أفضل الذكر، لا إله إلا الله، و أفضـــلـ

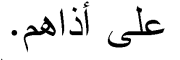

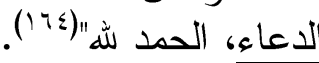

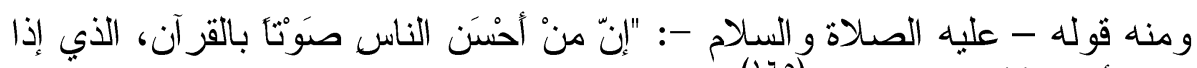

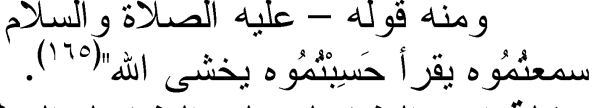

\section{دلالة اسم التفضيل على التفضيل حسبيل المطلق:}

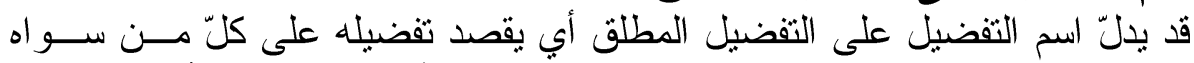

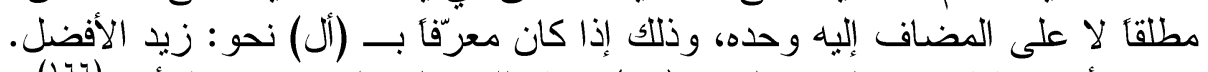

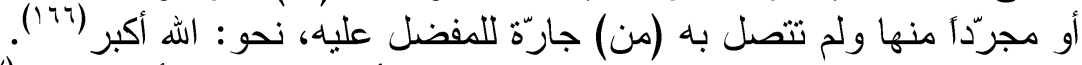

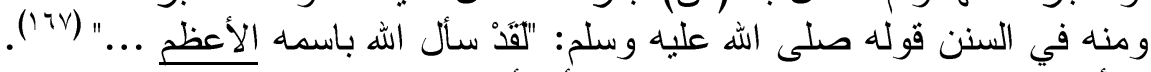

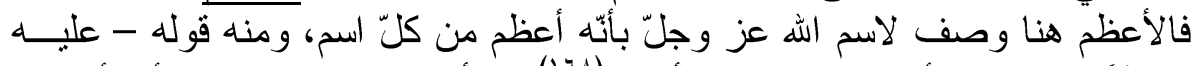

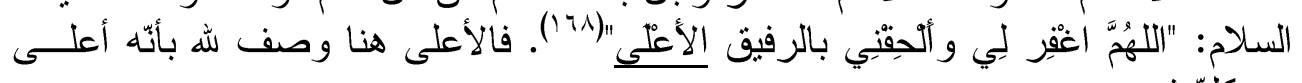

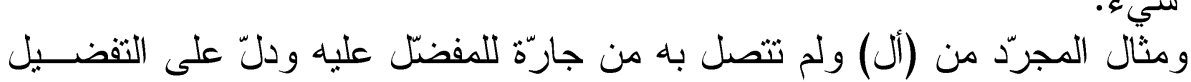

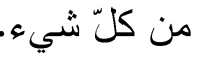

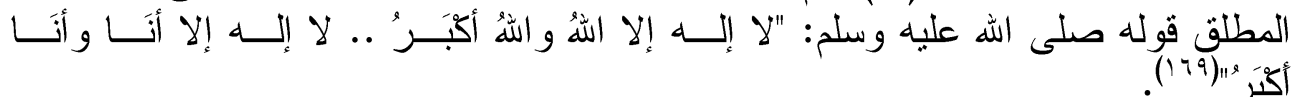




$$
\text { فقد دلت (أكبر) على التفضيل المطلق؛ لأنَّ اله أكبر من كل شيء. }
$$

\section{دلاكة اسم التفضيل على اسم الفاعل والصفة الفيل المشبهة:}

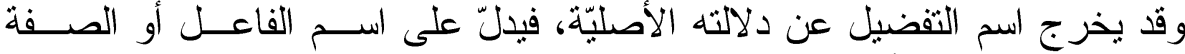

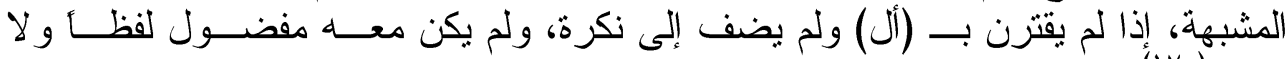
تقدير T) (iv) و هذا عند المبرّد مطرد، حيث قال: "و اعلم أن (أفعل) إذا أردت أن تضعه موضــع

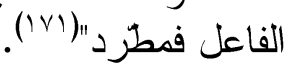

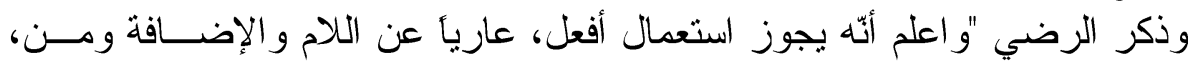
مجردأ عن معنى التفضيل مؤوّلا باسم الفاعل أو الصفة المشبهة قياسأ عند المبرد، سماعاً عند غيره، وهو معن الأصحح"(IVY)

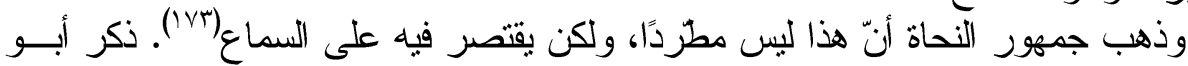

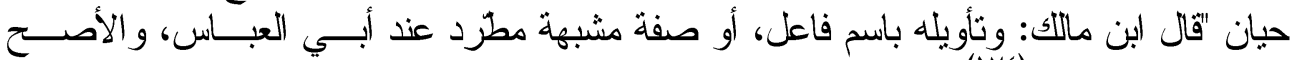

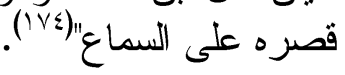

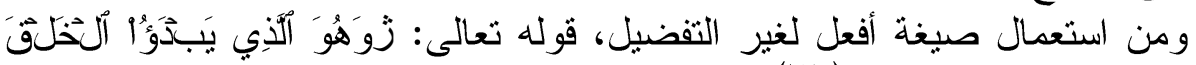

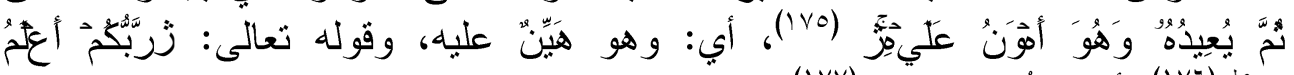

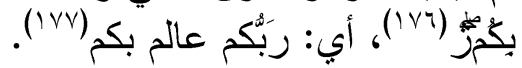

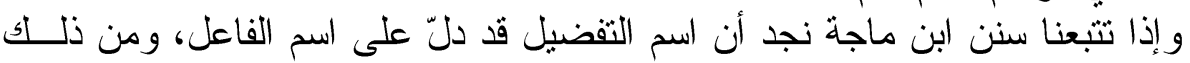

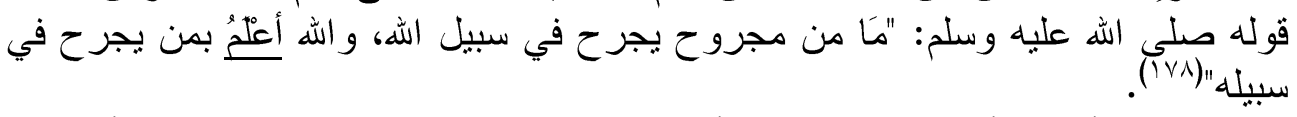
و (الله أعلم)، أي: عالم، ومنه - أيضاً - قوله - عليه السلام -: "... وهو أعٌٌْْ بما

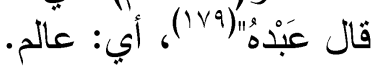

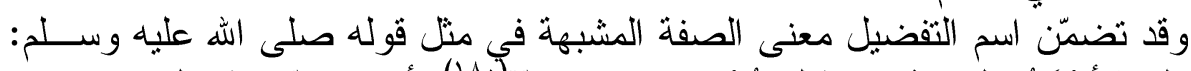

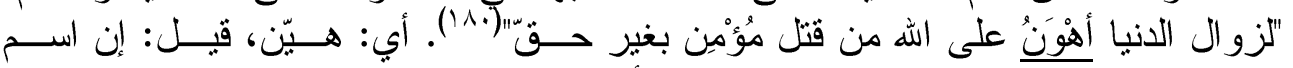

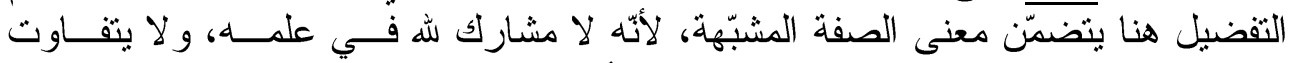

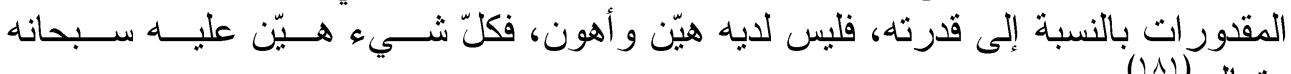

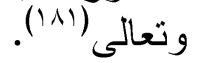
وذكر ابن يعيش "ويجوز أن بكون أهون ههنا بمعنى هيّن لأنه سبحانه ليس عليـــ

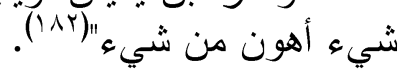

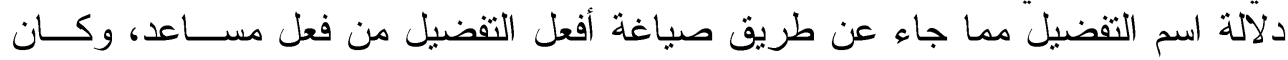

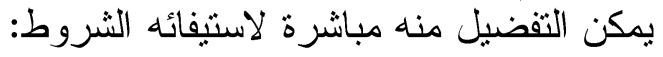

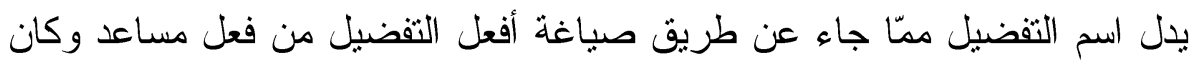

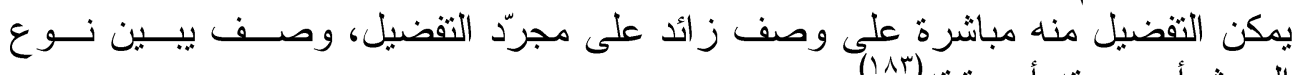

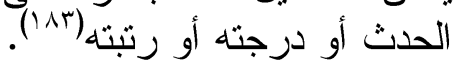

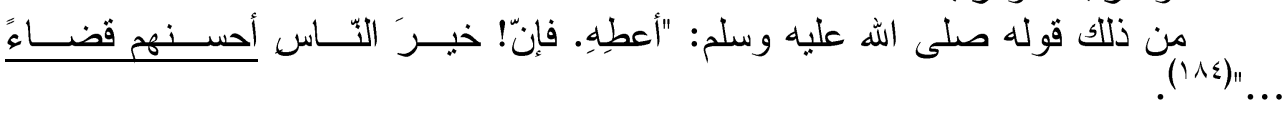
فــ (أحسنهم قضاء) لبس المقصود به مجرد التقضيل في القضـــاء بـلـل أحســنيته 
دلالة اسم التفضيل عن بعد الفاضل من المفضول، وتجاوزه عنه:

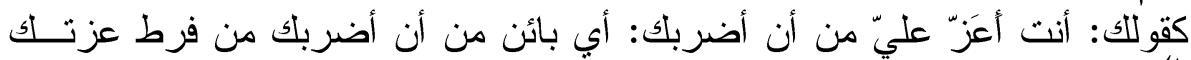

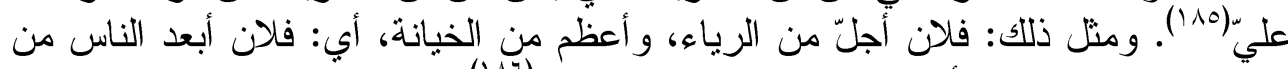

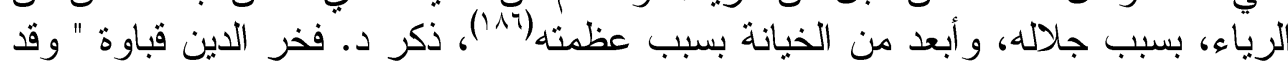

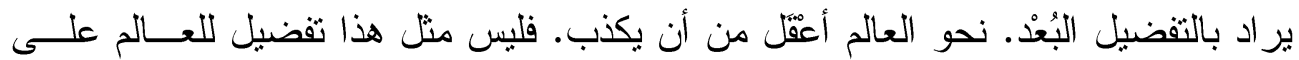

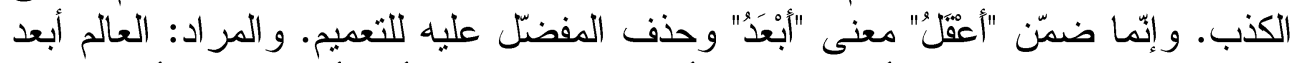

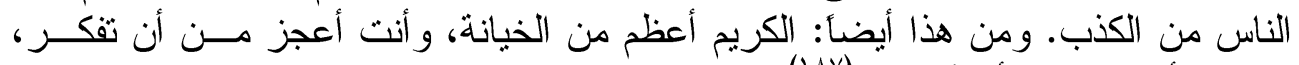

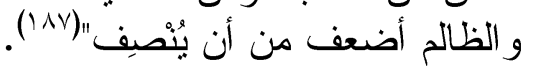
أمّا في السنن فلم ترد دلالة اسم التفضيل عن بعد الفاضل من المفضول، وتجـــاوزه

\section{دلالة أقُعَّل على غير التفضيل:}

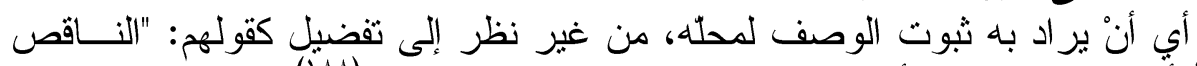

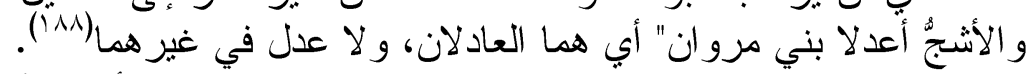

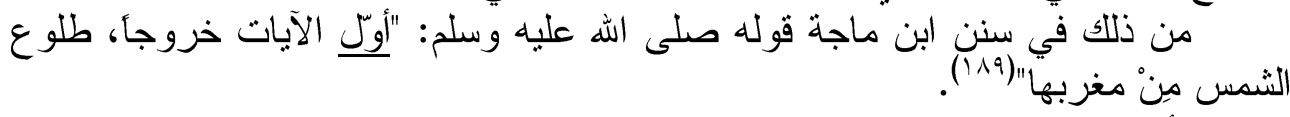
فأوّل هنا لا بر اد به ميه التقضيل.

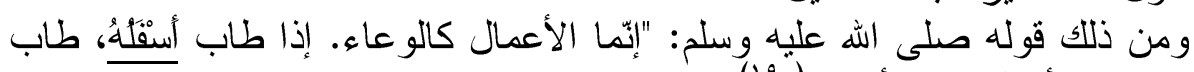

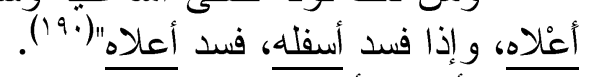

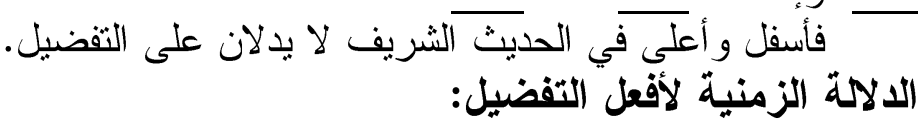

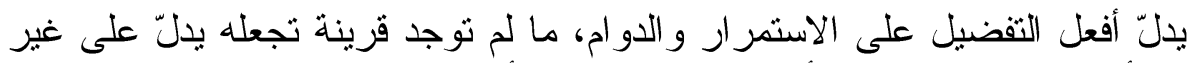

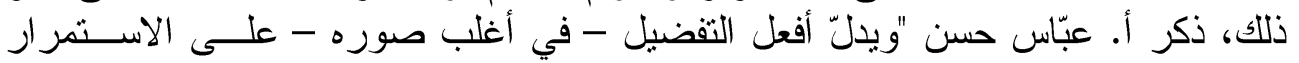

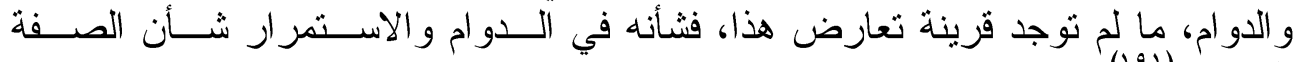

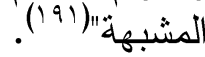
وأختم هذا الفصل بنتيجة استقر اء اسم التفضيل في سنن ابن ماجة من خلال جداول الحصر الآتية:

ا 1 - جدول صيغة (أقُعَل)

\begin{tabular}{|c|c|c|c|}
\hline طريقة ورودها & تكر ارها & المادّة & r \\
\hline أحسن، و أحاسن & 11 & أحسن & 1 \\
\hline الأعلى، و أعلاها & V & أعلى & $r$ \\
\hline \multirow{4}{*}{ الأدنى، أدناها } & 9 & أدنى & $r$ \\
\hline & $\varepsilon$ & أرفع & $\varepsilon$ \\
\hline & $1 \varepsilon$ & أثثد & 0 \\
\hline & 0 & أعلم & 7 \\
\hline الأحبّ،، و أحبّ & rY & أحبّ & V \\
\hline \multirow{4}{*}{ أوّل، و الأوَّلين، و الأوَّون } & 10 & أوّل & $\Lambda$ \\
\hline & $\varepsilon$ & آخر & 9 \\
\hline & $1 \varepsilon$ & أسفل & 1. \\
\hline & 1 & أرشد & 11 \\
\hline
\end{tabular}




\begin{tabular}{|c|c|c|c|}
\hline طريقة ورودها & تكرارها & المادّة & م \\
\hline \multirow{38}{*}{ أكثر ، و الأكثرون } & 0 & أصدق & Ir \\
\hline & 1 & أقضى & M \\
\hline & 1 & أ & $1 \varepsilon$ \\
\hline & r & أعظد & 10 \\
\hline & 1 & & 17 \\
\hline & 1 & أفرض & IV \\
\hline & 1 & أرحم & 11 \\
\hline & rᄉ & أفضل & 19 \\
\hline & 0 & أفقه & $r \cdot$ \\
\hline & 1 & أحفظ & r \\
\hline & 1 & أوعى & rr \\
\hline & 1 & أبغض & r \\
\hline & iV & أكثر & $r \varepsilon$ \\
\hline & 1 & بغن & ro \\
\hline & 1 & أنظف & ry \\
\hline & 1 & أزكى & rV \\
\hline & 11 & أطيب & $r \wedge$ \\
\hline & r & أطهر & rq \\
\hline & 1 & أندى أن & $r$. \\
\hline & 19 & أكبر & r \\
\hline & 1 & أرجح & r \\
\hline & 1 & أوزن & r \\
\hline & 1 & أزيد & $r \varepsilon$ \\
\hline & 0 & 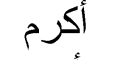 & ro \\
\hline & r & أبعد & ד \\
\hline & 1 & أنقل & rv \\
\hline & 1 & أقدم & rᄉ \\
\hline & r & أضعف & rq \\
\hline & r & أجود & $\varepsilon$. \\
\hline & $\varepsilon$ & أحرم & $\varepsilon$ \\
\hline & 1 & j. & $\varepsilon r$ \\
\hline & 1 & أمنع & $\varepsilon r$ \\
\hline & $\varepsilon$ & الأمثل & $\varepsilon \varepsilon$ \\
\hline & $\varepsilon$ & أخوف & $\leqslant 0$ \\
\hline & r & أطول & $\varepsilon 7$ \\
\hline & r & أمدّ & $\leqslant V$ \\
\hline & 1 & أسمن & $\varepsilon \wedge$ \\
\hline & 1 & أدَرَّ & $\leqslant 9$ \\
\hline
\end{tabular}




\begin{tabular}{|c|c|c|c|}
\hline 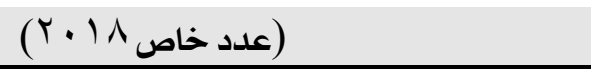 & & س - - إس & 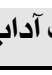 \\
\hline طريقة ورودها & تكر ارها & المادّة & r \\
\hline & 1 & أجود & 0 \\
\hline & 0 & أهون & 0 \\
\hline & 1 & أغبط & 0 \\
\hline & 1 & أحق & or \\
\hline & 1 & أجدر & 0 \\
\hline & 1 & أعبْدَ & 00 \\
\hline & 1 & أشكر & $0^{-}$ \\
\hline & r & أقلّ & 01 \\
\hline & 1 & أنقى & 01 \\
\hline & 1 & أشقى & $0^{\circ}$ \\
\hline & 1 & أبسر & 7 \\
\hline & 1 & أفظع & 7 \\
\hline & 1 & & 7 \\
\hline & r & أحلى & 7 \\
\hline & 1 & أعمّ مَّ & 7 \\
\hline & 1 & أكفى & 70 \\
\hline & 1 & أنعم & 7 \\
\hline & r & أحق & 7 \\
\hline & 1 & أوثق & 7 \\
\hline & 1 & أنفس & 70 \\
\hline & 1 & أغلى & $V$ \\
\hline & 1 & أغضّ & V \\
\hline & 1 & أحصن & V \\
\hline & 1 & أعذب & Vr \\
\hline & 1 & أنتق & $V$ \\
\hline & 1 & أرضى & Vo \\
\hline & 1 & أحرى & $v^{-}$ \\
\hline & 1 & أجدر & v \\
\hline & 1 & أعدل & VI \\
\hline & 1 & أعفّ & $V^{c}$ \\
\hline & $\varepsilon$ & أوْْى & $\wedge$ \\
\hline & 1 & أنفع & $\wedge$ \\
\hline & 1 & أهنيْبُ & $\wedge$ \\
\hline & 1 & أرغب & $\wedge r$ \\
\hline & 1 & أرضى & $\wedge$ \\
\hline \multirow[t]{2}{*}{ الأقصى، و أقصاهم } & 0 & أقصى & $\Lambda c$ \\
\hline & סמי & \multicolumn{2}{|c|}{ المجموع } \\
\hline
\end{tabular}




\begin{tabular}{|c|c|c|c|}
\hline طريقة ورودها & تكرارها & المادّة & p \\
\hline وردت بلفظ خير ، وخيار & 11. & خير & 1 \\
\hline وردت بلفظ شرّ، وشِر ار & $\pi$ & 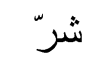 & r \\
\hline & $M T$ & & \\
\hline
\end{tabular}

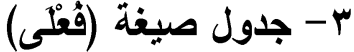

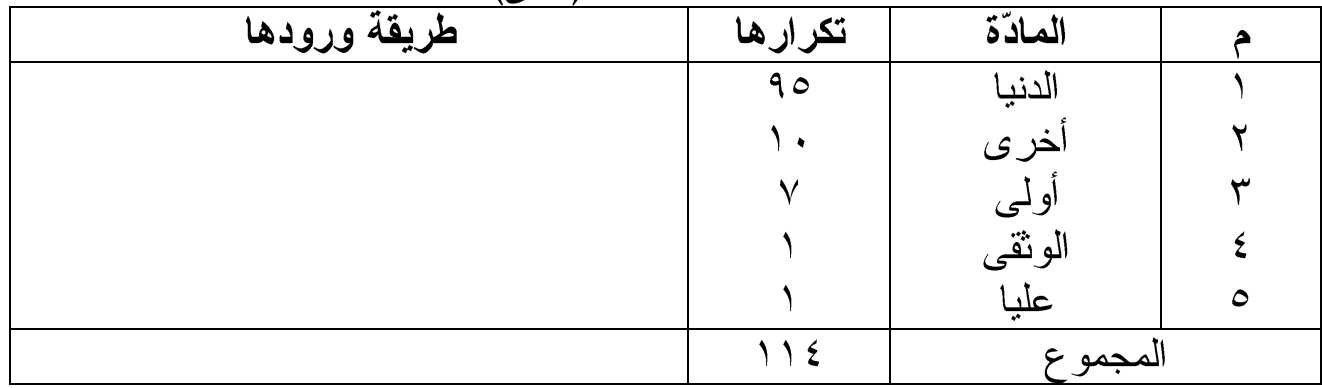

\begin{tabular}{|c|c|c|c|}
\hline \multicolumn{4}{|c|}{ ع - حالات اسم التفضيل } \\
\hline طريقة ورودها & تكرارها & 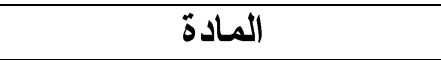 & s \\
\hline & 104 & المجرد وذكرت بعده (من) & 1 \\
\hline & $\wedge \varepsilon$ & المجرد وحذفت بعده (من) & $r$ \\
\hline & $1 \varepsilon$. & المقترن بــ (أل) & r \\
\hline & 171 & المضاف إلى المعرفة & $\varepsilon$ \\
\hline & 9 & المضاف إلى النكرة & 0 \\
\hline & 1 & محلَّى بأل وذكرت بعده (من) & 7 \\
\hline & $0 \leqslant \Lambda$ & المجموع & \\
\hline
\end{tabular}

$$
\text { وبعد عرض هذه الجداول نستنتج الآتي: }
$$

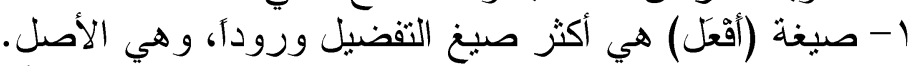

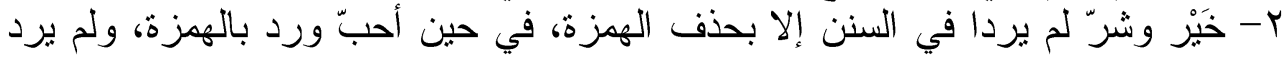

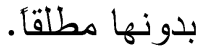

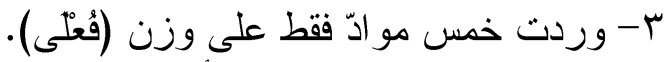

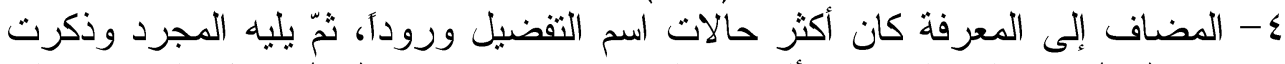

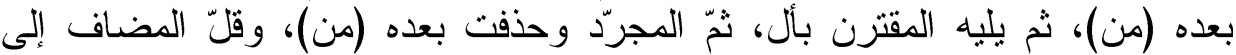

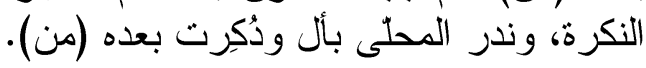




\section{الخاتمة}

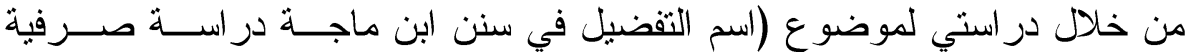

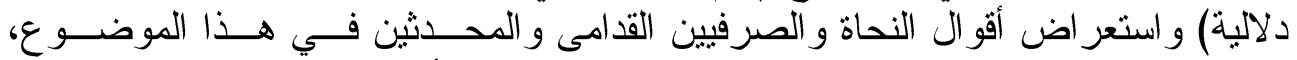

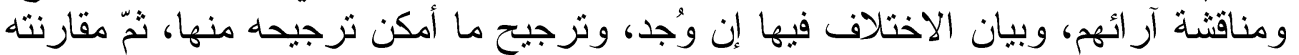
بالو اقع اللغويّ في سنن ابن ماجة، توصتّلت إلى النتائج الآتية:

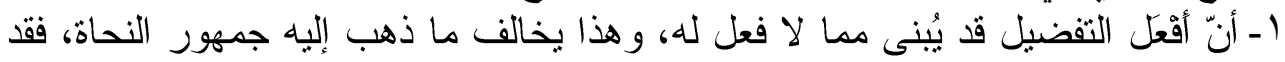

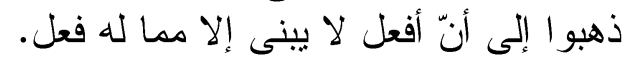

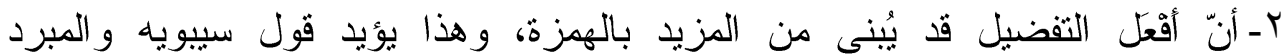

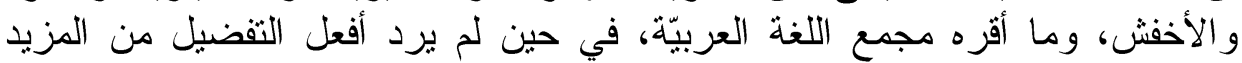

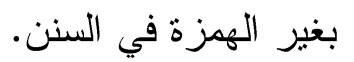

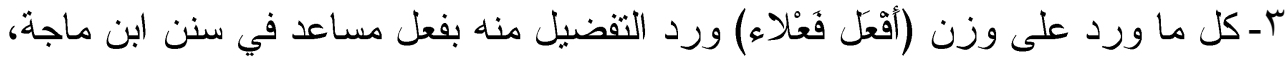

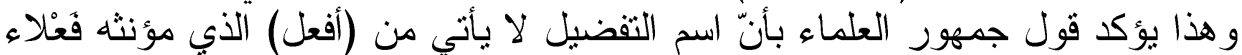

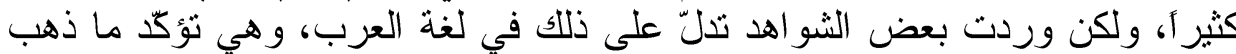

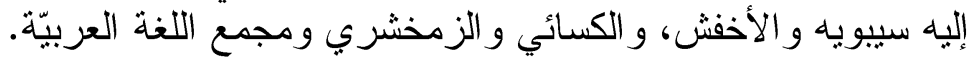

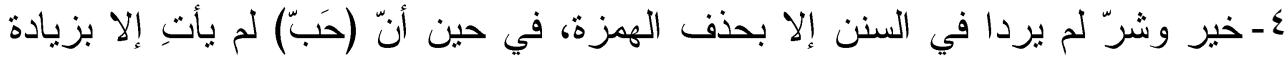

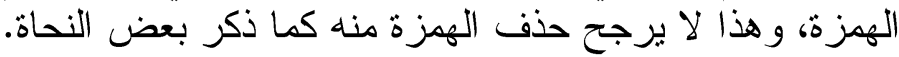

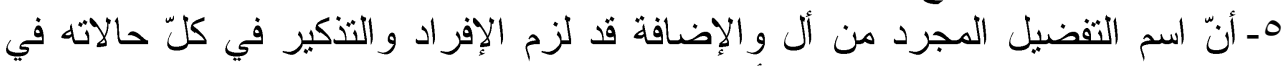

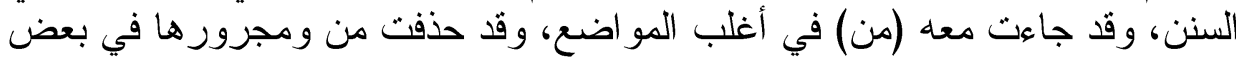

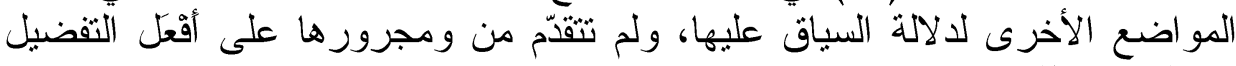

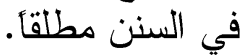

7- أنّ أفعل الثنضيل المعرّت بأل قد تتصل به من ومجرورها قليلا أو نادر أ.

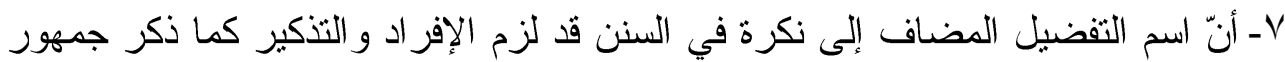

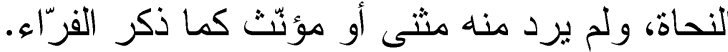

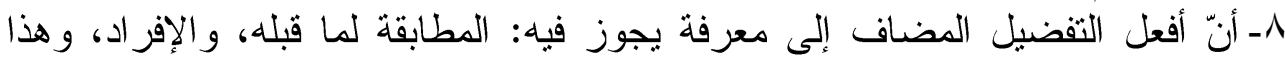

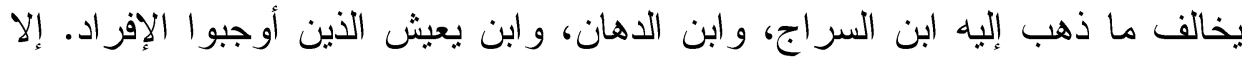

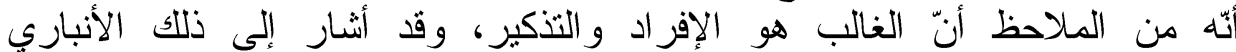

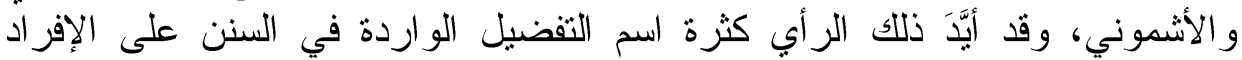

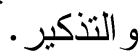

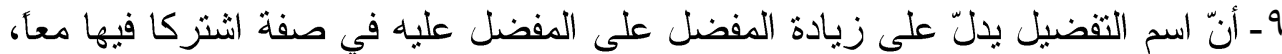

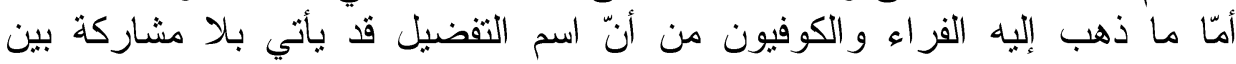

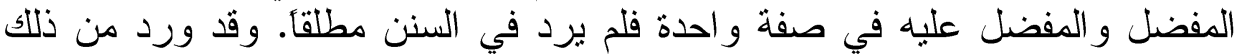

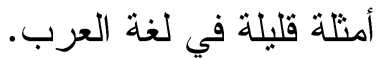
• اـ أنّ اسم التفضيل قد يخرج عن دلالته الأصليّة ليدلّ على التفضيل المطلق، أو ليدلّ اليّل

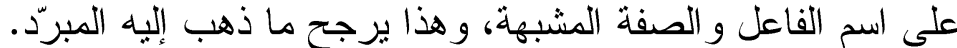
11 أ أنّ أفعل التفضيل قد يستعمل لغير التفضيل وقد وردت أمثلة لذلك في السنن. 


\section{Abstract \\ Preferences in Ibn Magah Prophet Speeches Collection \\ Grammatical Indicative Study \\ By Salma Muhammad Salim Hafiza}

This treatise is a grammatical indicative applicable study of the speeches of prophet Mohamed, peace be upon him, in Ibn Magah collection of the Prophet speeches. In this Treatise I counted the preference name therein, and classified them according to the language and grammar scientists, I indicated the opinions of the old language and grammar scientists in this subject at the grammatical and indicative levels and cited their opinion, and discussed any differences; then I studied them by applying them to the speeches of Prophet Mohamed, peace be upon him, showing the extent of agreement and disagreement with them.

This Treatise includes an introduction, preface, study content and conclusion which include the main results of the Treatise. I also included a list with the references which helped me in the preparation of this Treatise.

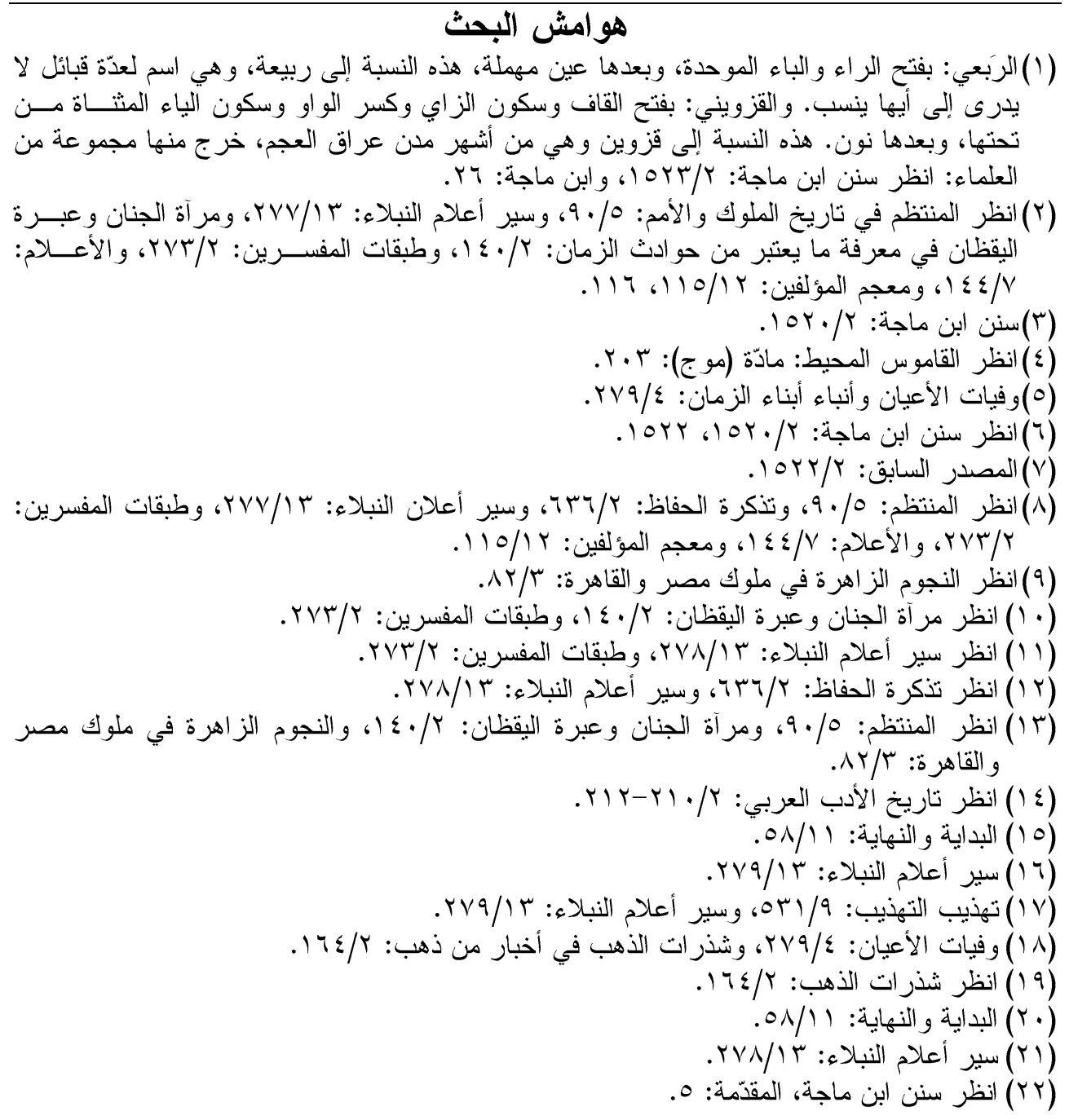




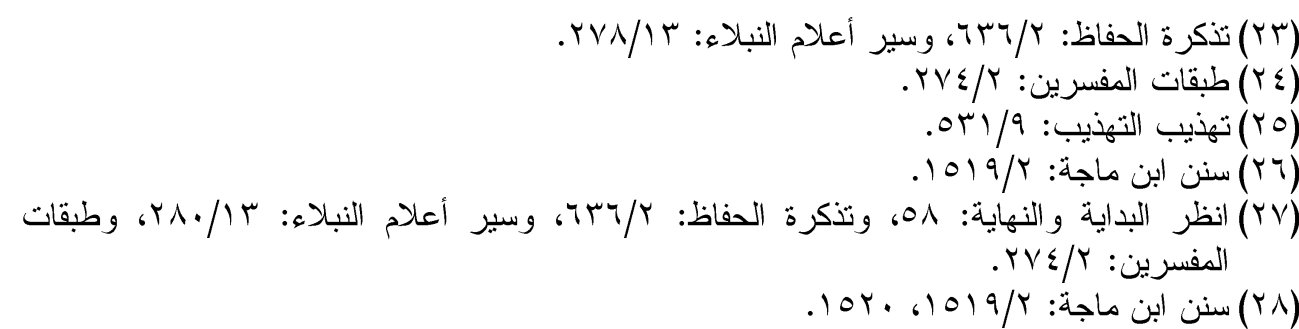

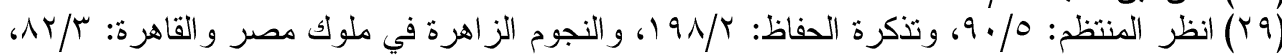

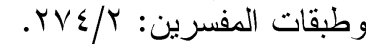

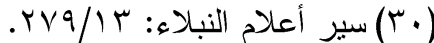

(اس) شرح الرضيّ على الكافية:

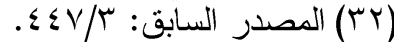

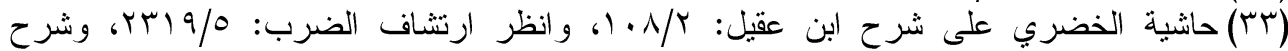

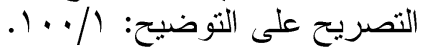

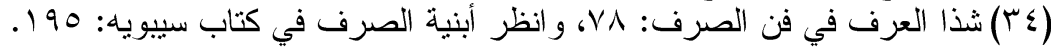

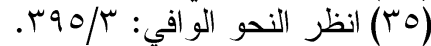

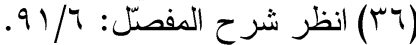

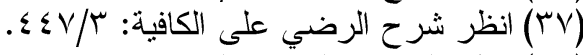

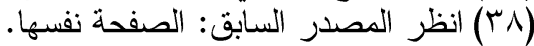

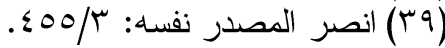

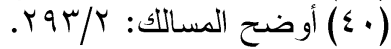

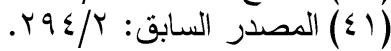

( ) شر)

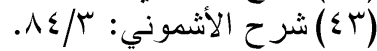

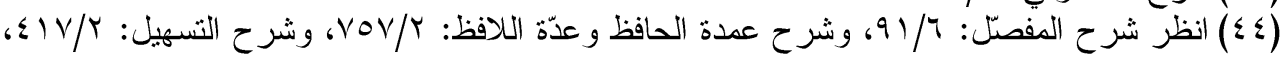

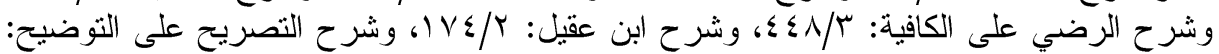

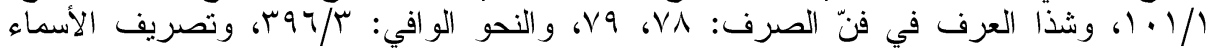

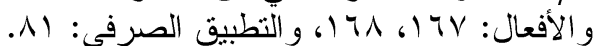

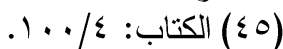

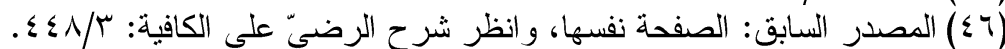

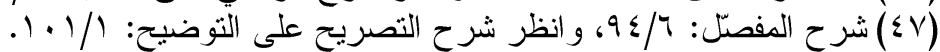

إ)

(9) سنن ابن ماجة، المقدمة، كتاب باب في فضائل أصحاب رسول الله صلى الله عليه وسلم. ؟ــ1:

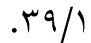

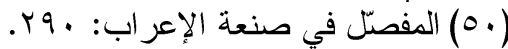

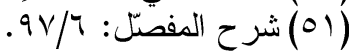

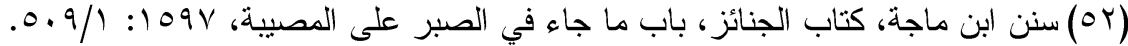

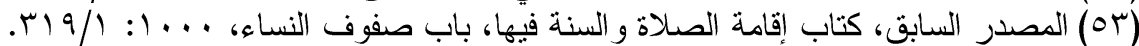

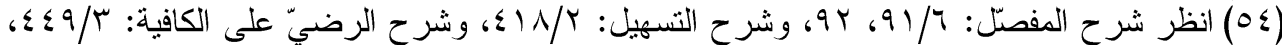

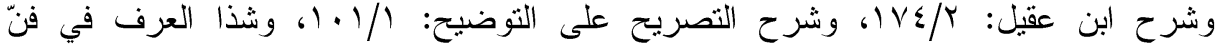

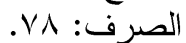

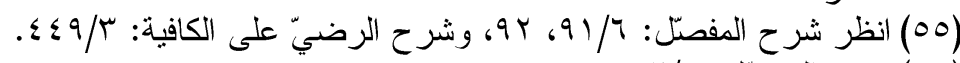

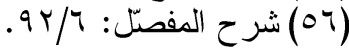

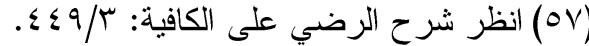

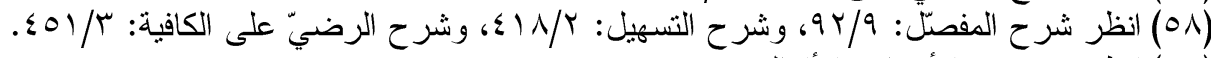

(09) انظر تصريف الأسماء و الأفعال:

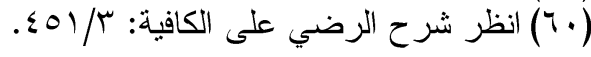




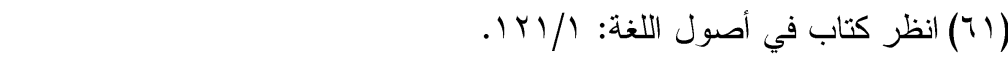

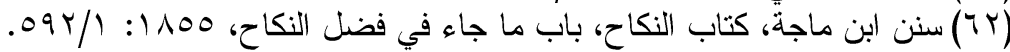

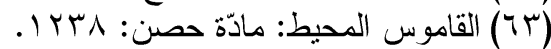

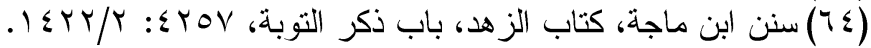

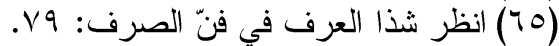

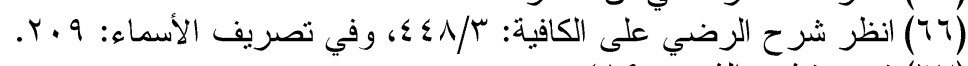

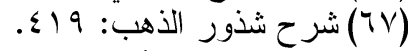

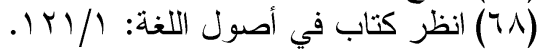

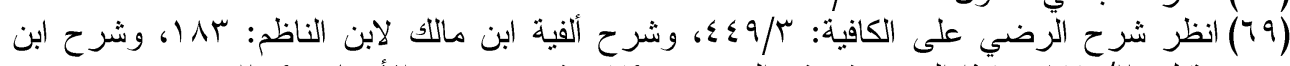

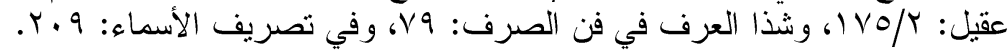
(V•)

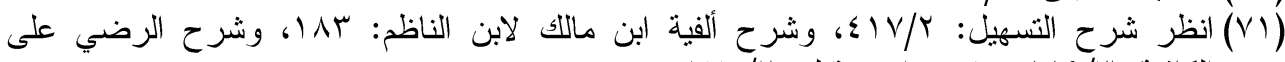

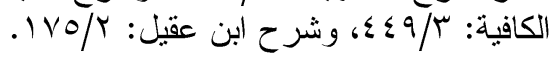

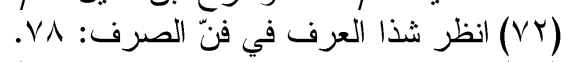

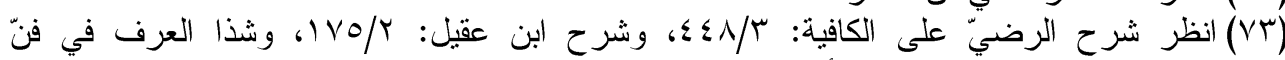

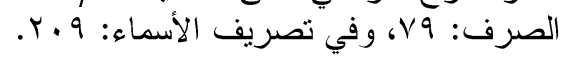

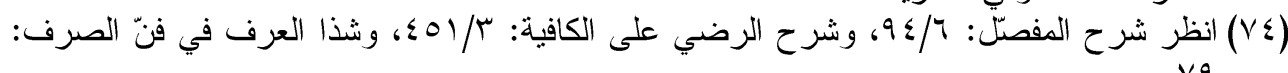
. V 9

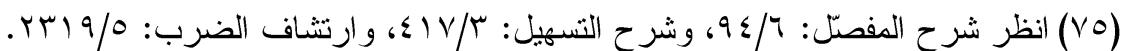

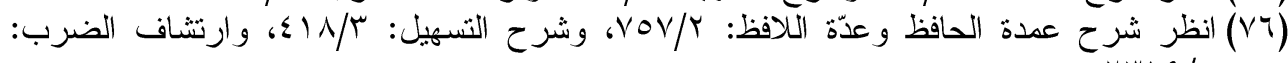
19/0

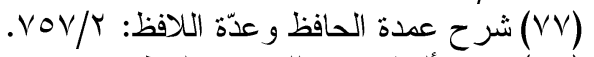

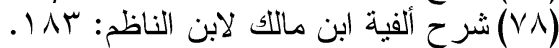

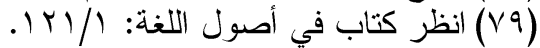

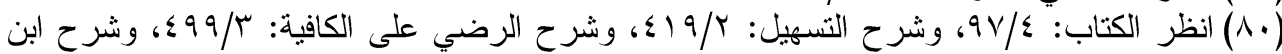

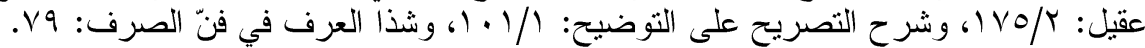

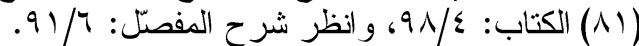

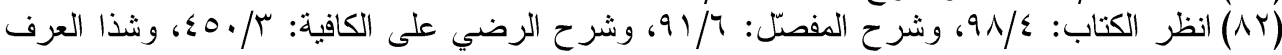

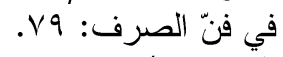

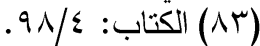

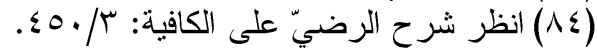

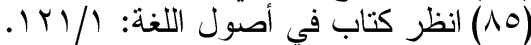

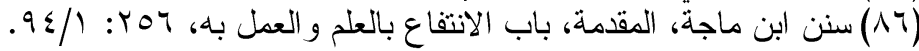

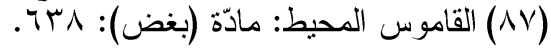

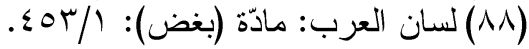

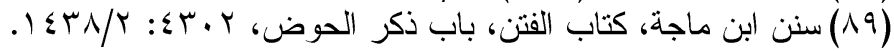

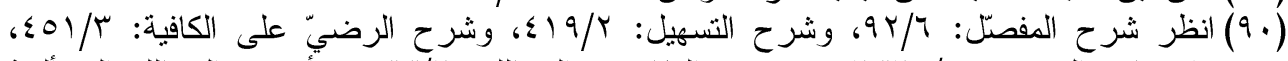

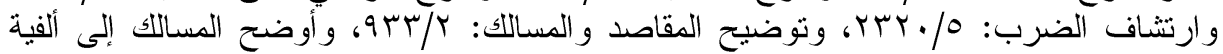

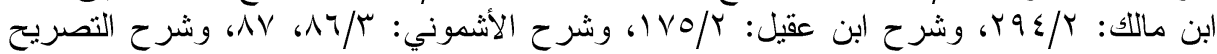

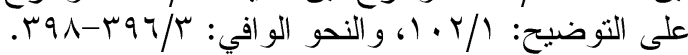

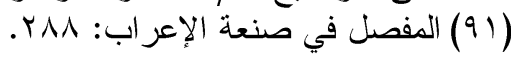

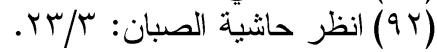
( ) ( (

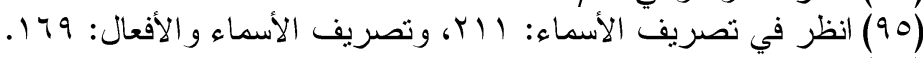

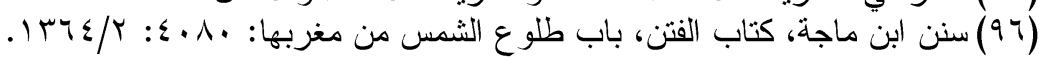




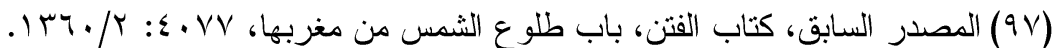

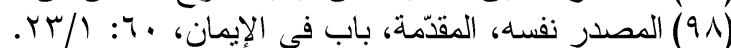

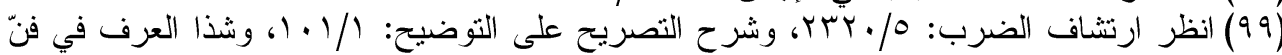

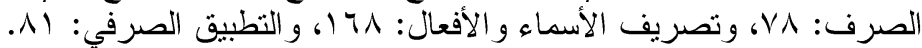

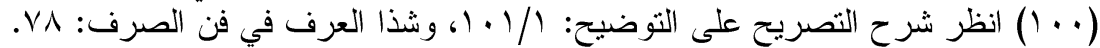

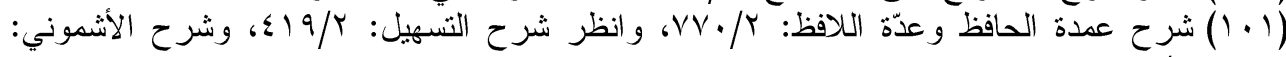

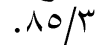

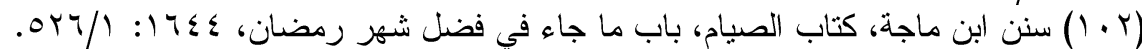

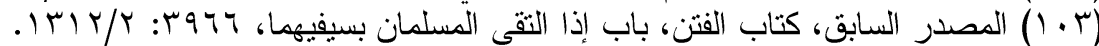

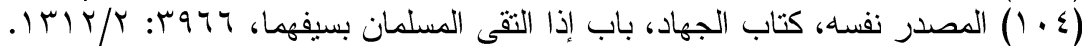

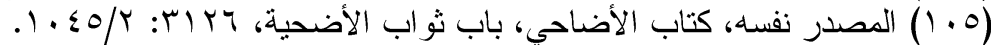

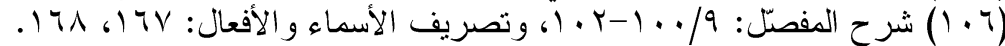

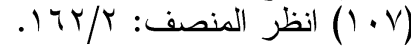

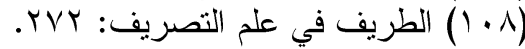
(9 ( ) سنن ابن ماجة، كتاب إقامة الصلاة و السنة فيها، باب ما جاء فيمن أدرك من الجمعة ركعة،

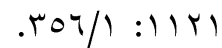

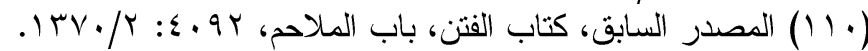

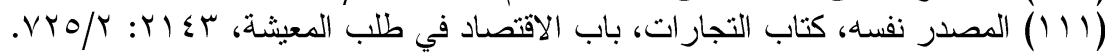

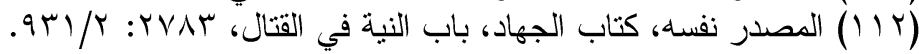

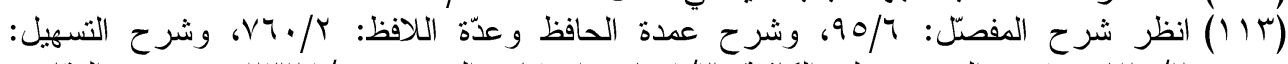

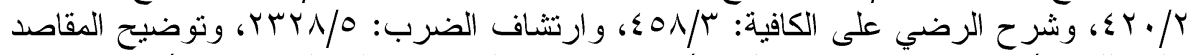

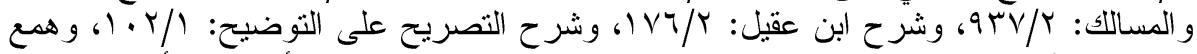

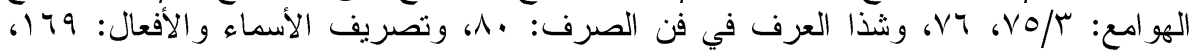

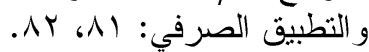

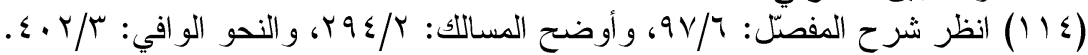

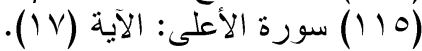
(V)

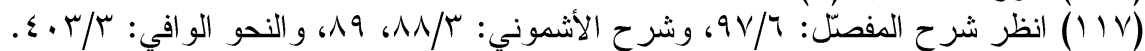

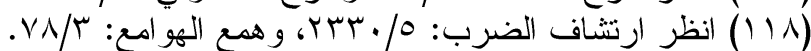

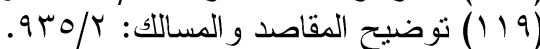

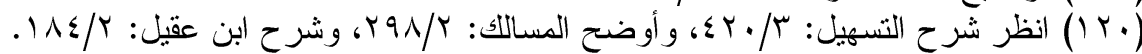

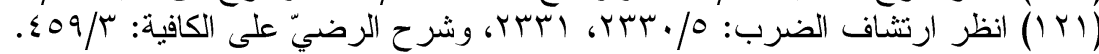

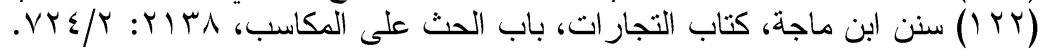

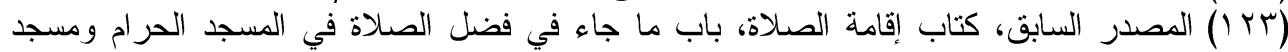

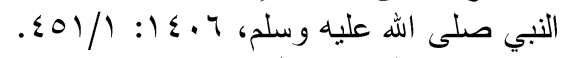

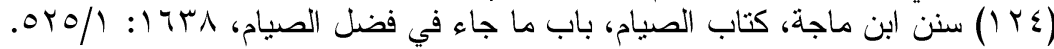

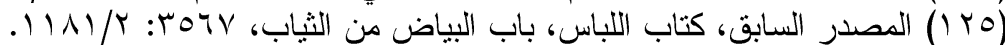

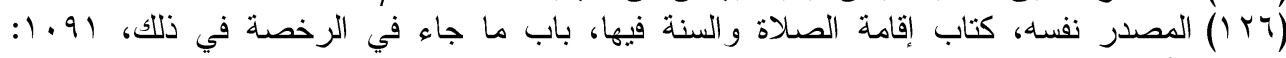
r r $r$ V $/ 1$

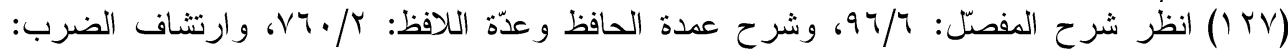

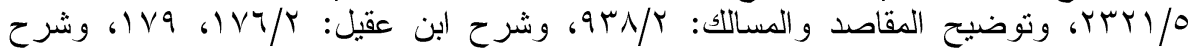

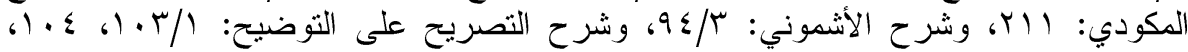

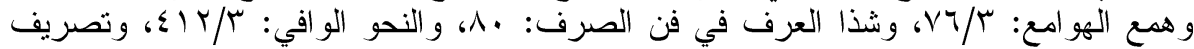

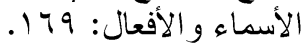

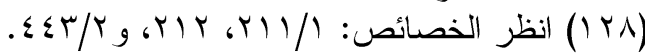

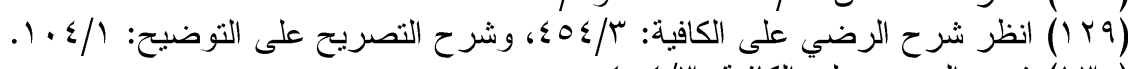

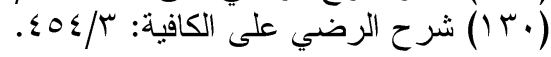


(آाا) ديو ان الأعشى، تقديم وشرح وتعليق د. محمد حمود، طا، دار الفكر اللبناني، بيروت، ب999 ام:

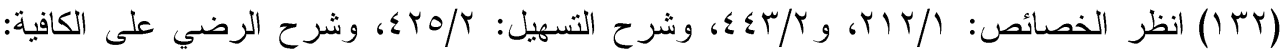

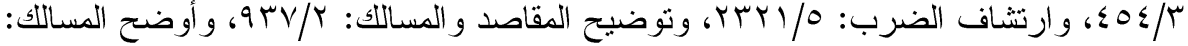

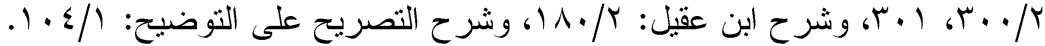

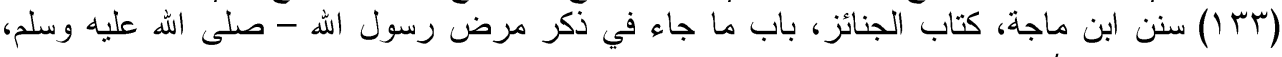
$.01 \mathrm{~V} / 1: 1719$

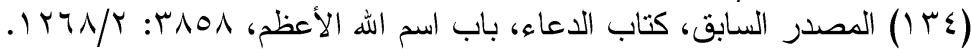

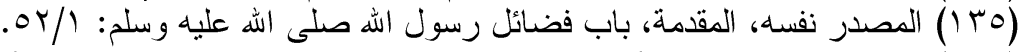

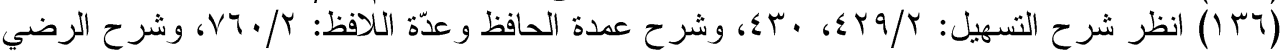

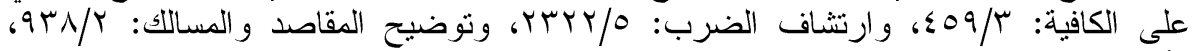

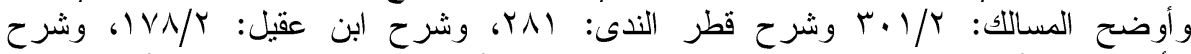

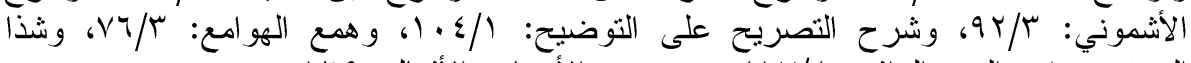

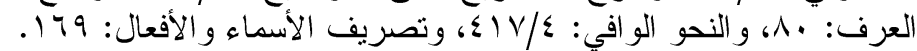
ا

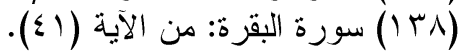

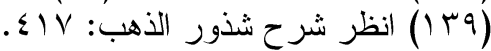

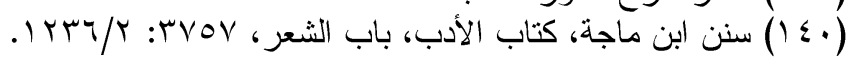

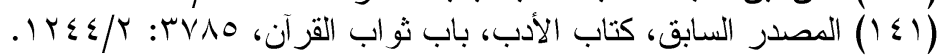

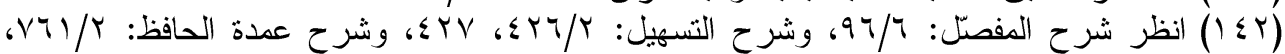

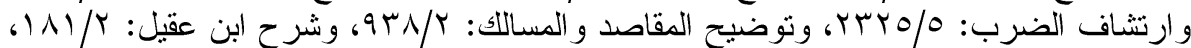

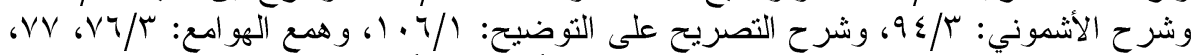

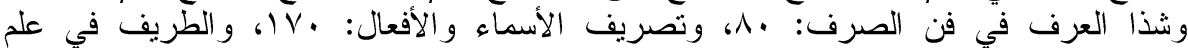

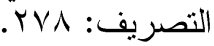

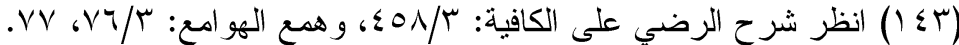

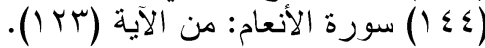

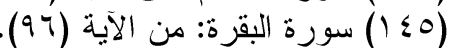

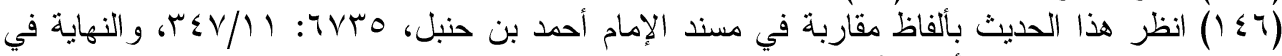

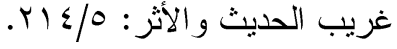

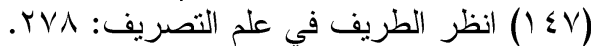

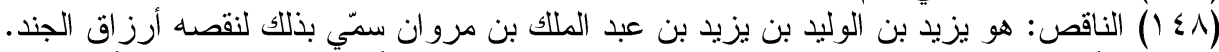

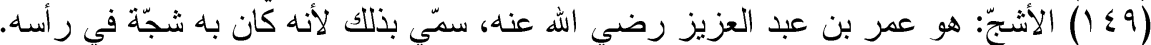

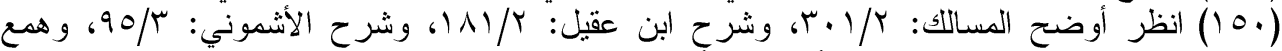

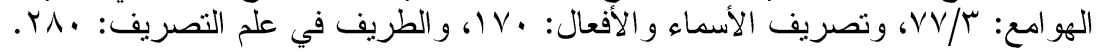

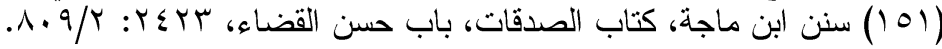

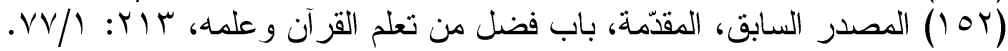

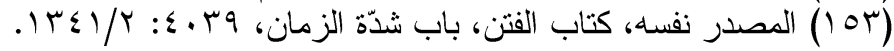

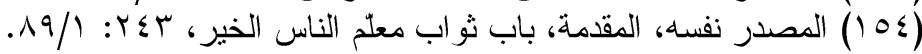

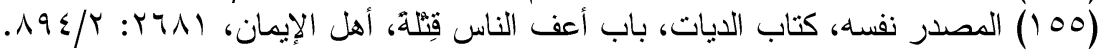

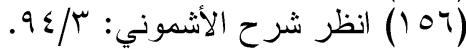

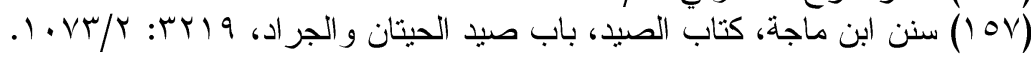

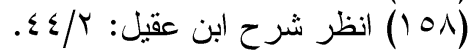

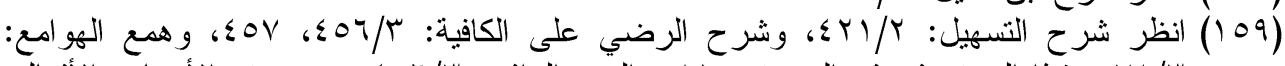


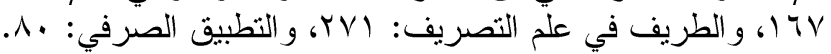

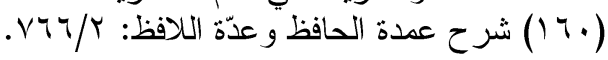




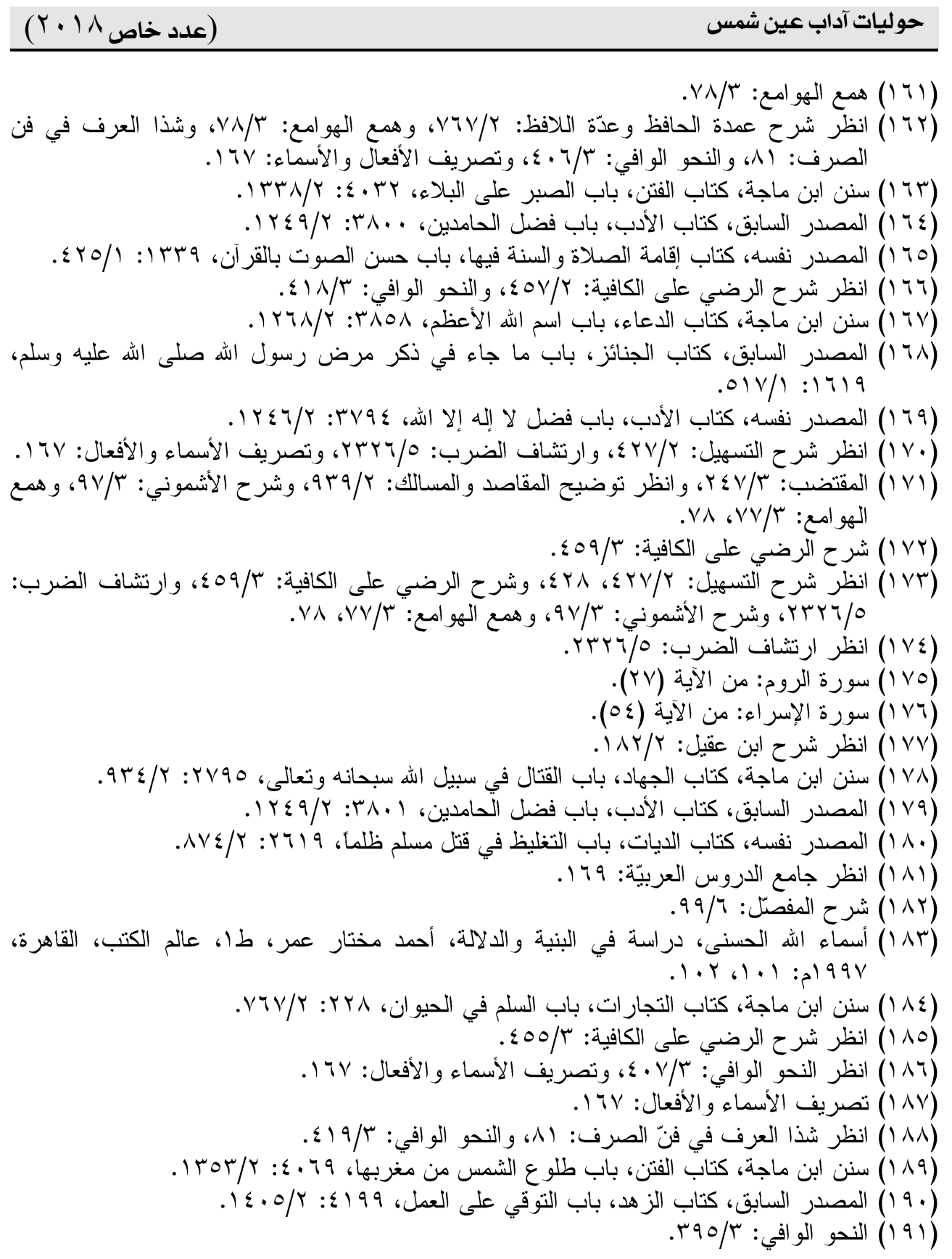




\section{مصادر ومراجع البحث}

- القرآن الكريم برواية حفص عن عاصم.

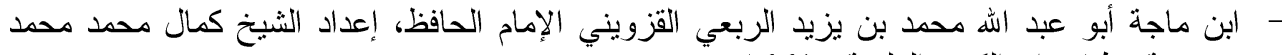

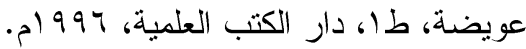

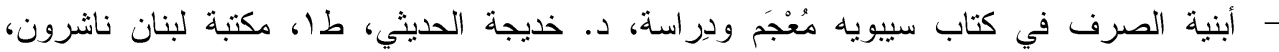

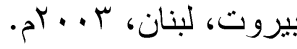

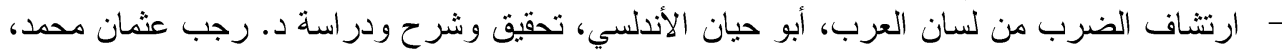

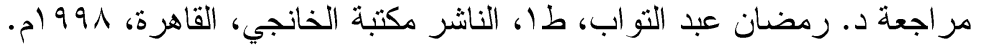

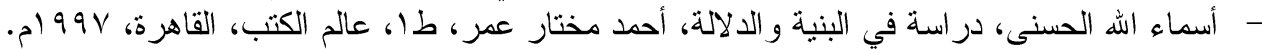

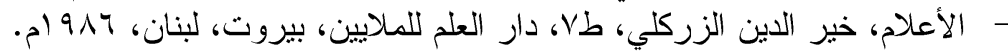

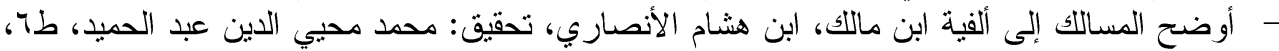

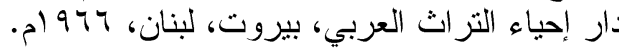

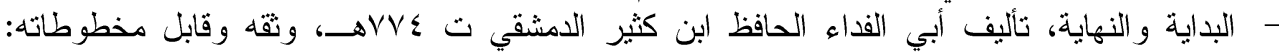

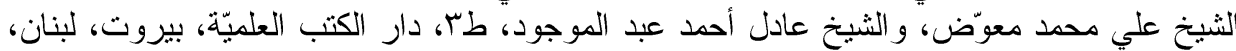
. . 9

- تاريخ الأدب العربي، كارل بروكمان، الإشر اف على الترجمة العربية أ.د. محمود فهمي حجازي، بلا

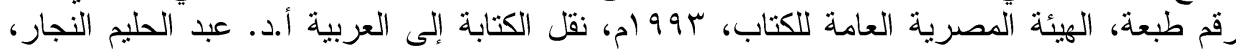

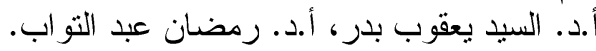

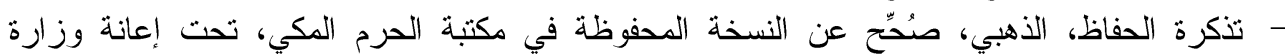

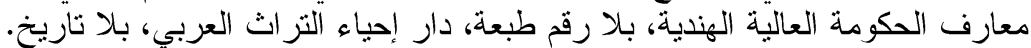

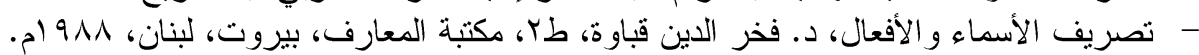

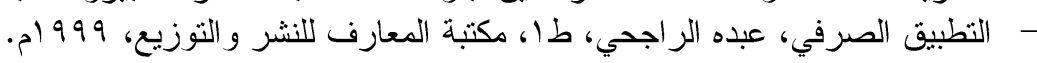

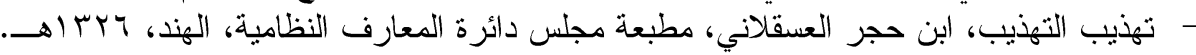

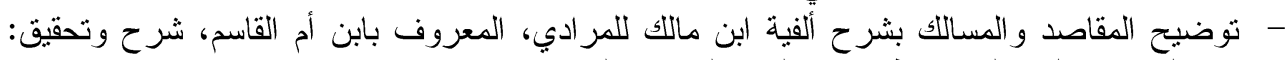

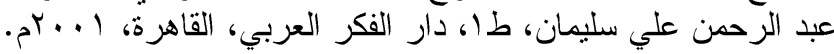

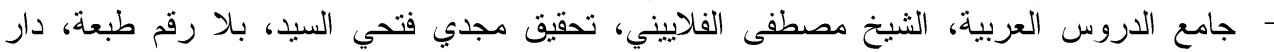

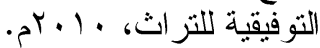
- حاشية الخضري على شرح ابن عقيل على ألفية ابن مالك،، شرحها و وعلق عليها تركي فرحان

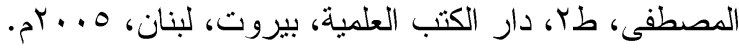

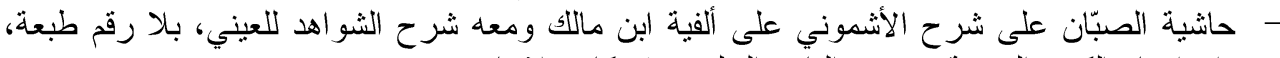

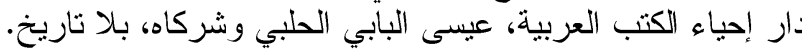

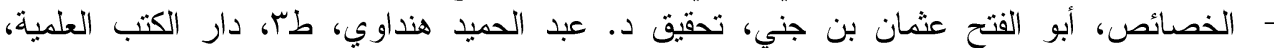

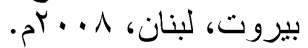
- ديو ان الأعثى، تقديم وشرح و تعليق د. محمد حمود، طا، دار، دار الفكر اللبناني، بيروت، 999 ام.

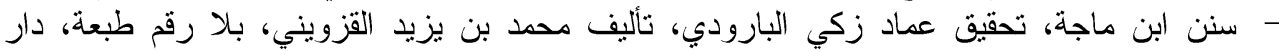

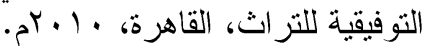

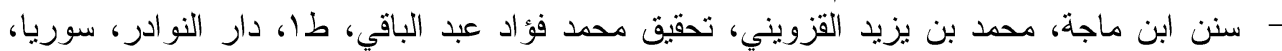

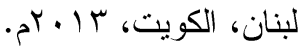

- سير أعلام النبلاء، شمس الدين محمد بن أحمد بن عثمان الذهبي، طا اه مؤسسة الرسالة، 991 ام.

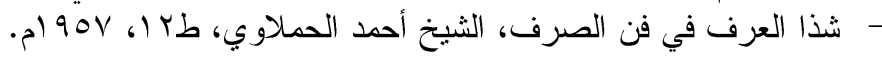

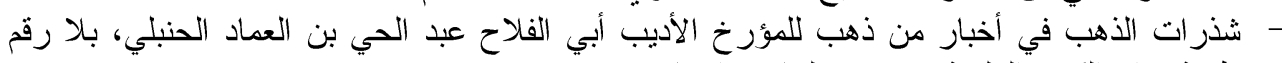

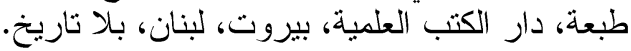

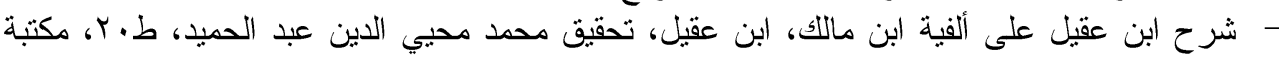

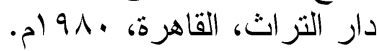




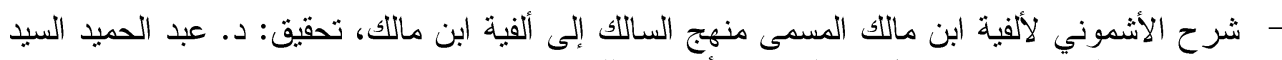

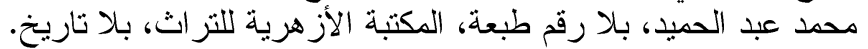

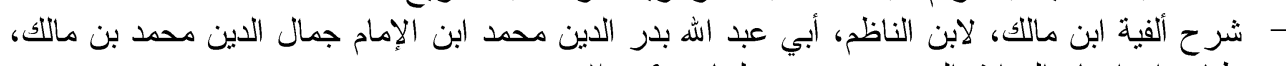

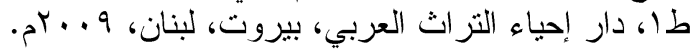

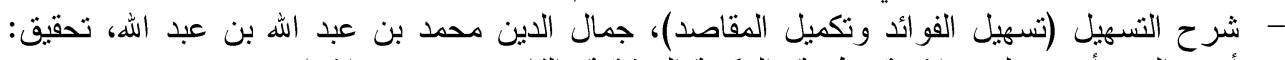

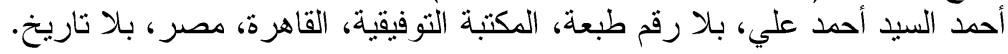

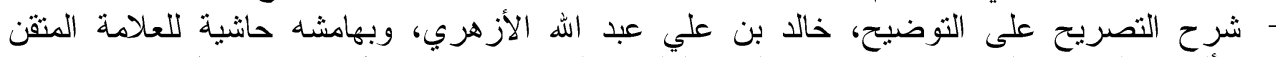

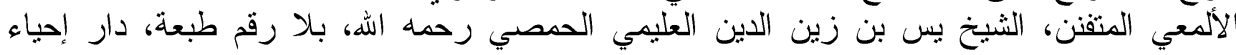
الكتب العربية، عيسى البابي الحلبي وشركاه، بلا تاريخ.

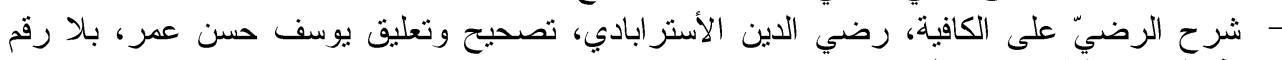

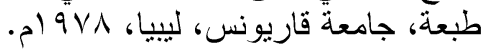

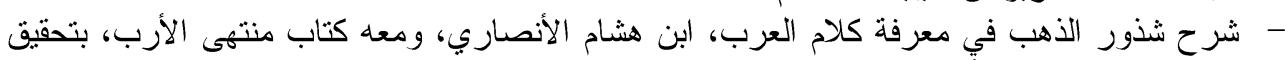

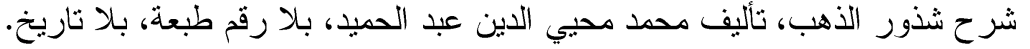

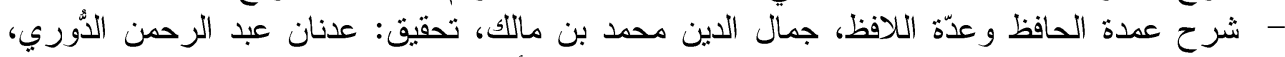

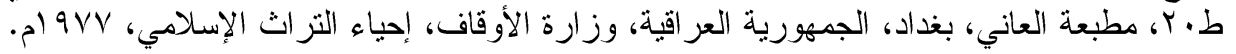

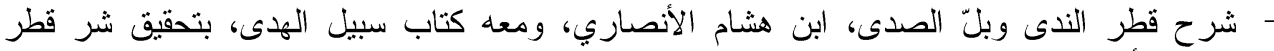

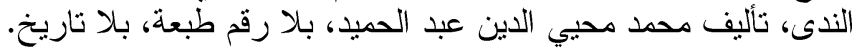
- شرح المفصّل، موفق الدين بعيش بن علي بن يعيش النحوي، بلا رقم طبعة، عالم الكتب، بيروت، بلا بلا تاريخ.

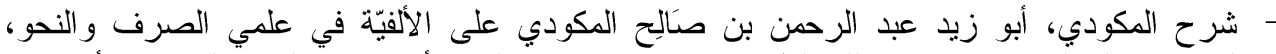

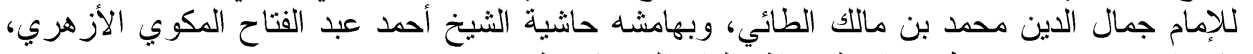

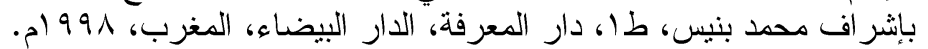

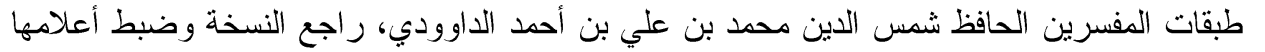

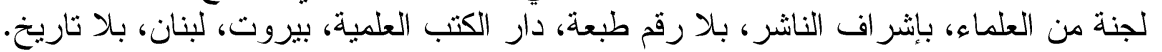

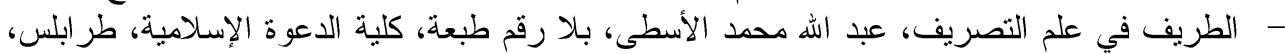
ليبيا، بوان في 199. -

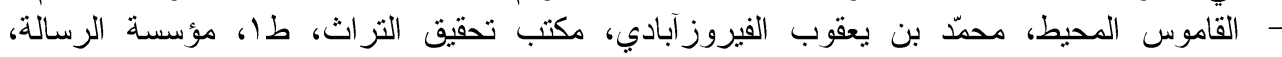
.21914

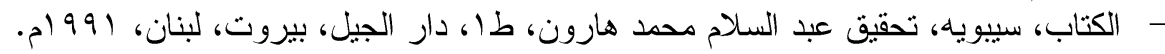

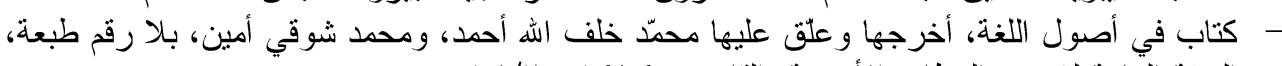

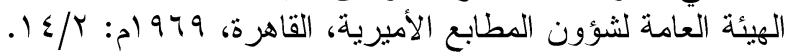

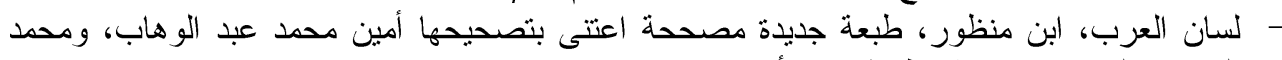
الصادق العبيدي، بلا رقم طبعة، بلان تأريخ.

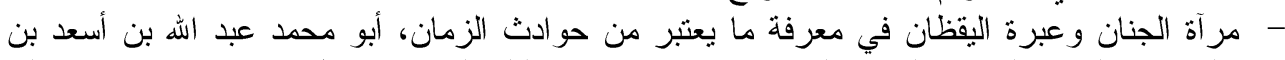

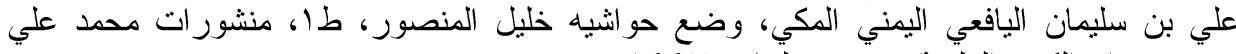

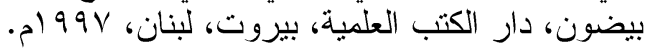

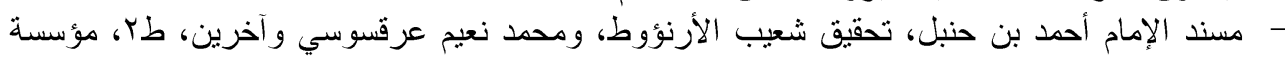

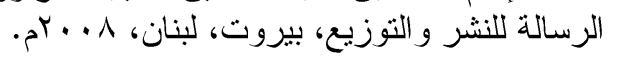

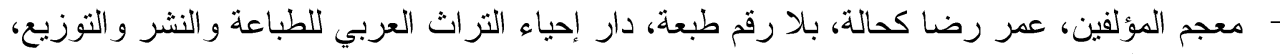
بيروت، لبنان، بلا تاريخ.

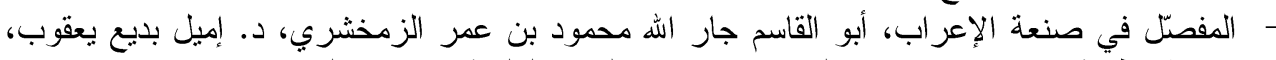

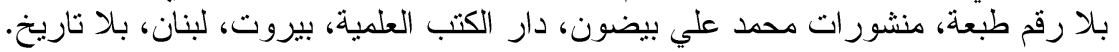

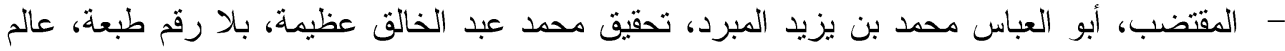
الكتب، بيروت، لبنان، بلا تاريخ. 
- المنتظم في تاريخ الملوك والأمم، أبو الفرج عبد الرحمن بن علي الجوزي، طان، مطبعة دائرة

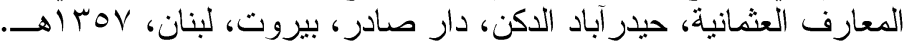

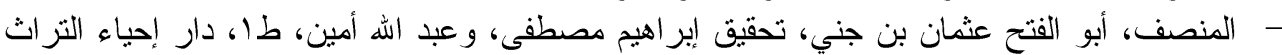

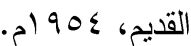
- - النحو الو افي، عباس حسن، طء، دار المعارف، القاهرة، مصر، بلا تاريخ.

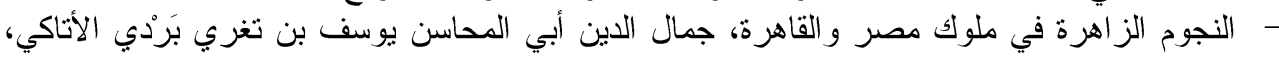

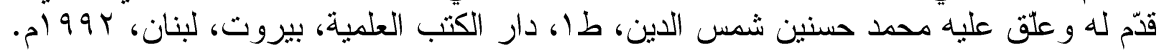

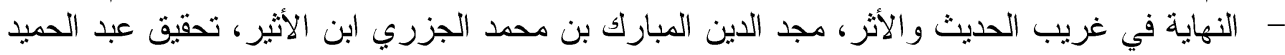

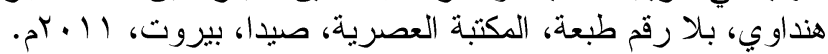

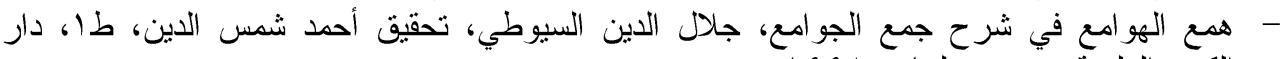

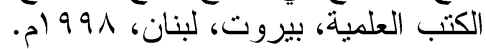
- ـ وفيات الأعيان و أنباء أبناء الزمان، لبنان، ابن خلكان، تحقيق د. إحسان عبّاس، بلا رقم طبعة، دار صادر،

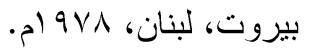

